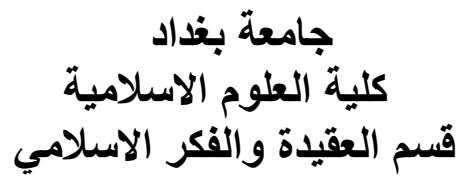

\title{
نظرية الأهوال
}

بين القائلين بها والنافين ها والمترددين فيها

دراسة نقدية وقراءة تثليلية

\author{
تأليف \\ أ.م.د \\ ثُائر ابراهيم الشمري
}


$-9 \leqslant 7-$ 


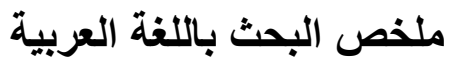

تــسب نظريـة الأحوال للمـتكلم المحقـق أبـي هاثـــم الجبائي المعتزلـي

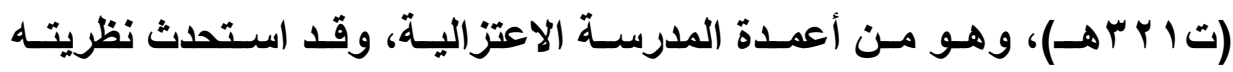

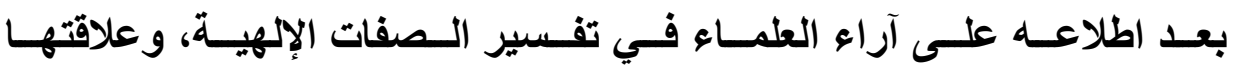

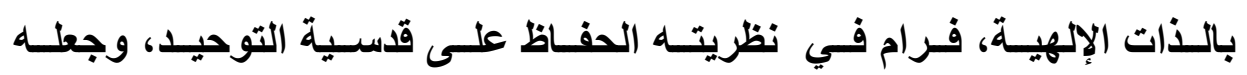
بعيداً عن الشرك وشـوائبه، ولـم تكن نظريتهـ بعيدة عن دراسـة معاصريه

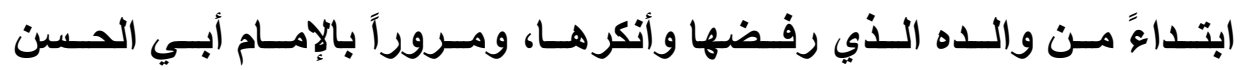
الأشعري إمام الأشاعرة من أهل السنة.

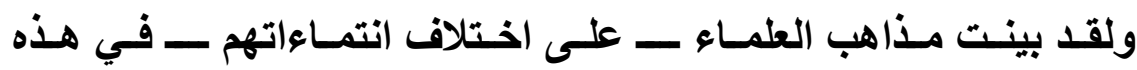
النظرية، وأتيت بأدلة المؤدين وناقثتها، والله تعالى أعلم.. 
Research Summary

Attributed weather theory to the speaker investigator Abi Hashim Aljbaia Mu'tazili (d. rr I AH), a school columns Alaatzalah, has developed his theory after studying the views of the scientists in the divine interpretation, and their relationship to the divine self, Wolfram of his theory to maintain the sanctity of unification, and make it away from polytheism and Hoaibh, and did not not far from his theory of the study of his contemporaries, starting from his father, who rejected and denied, through Imam Abu al-Hasan al-Ash'ari Imam Ash'aris of Sunnis.

The doctrines of scientists showed their different affiliations in this theory, and the evidence performers come and discussed, and God knows .. 


\section{المقدمة}

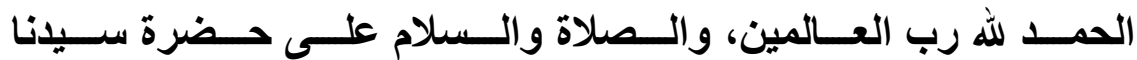

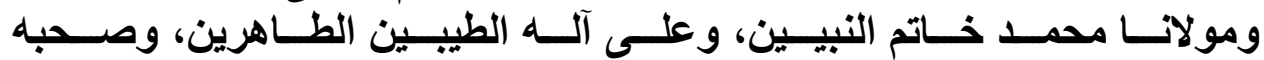
الغيارى الصادقين، ومن تبعه بإحسان إلى يوم الاين.

$$
\text { أما بعد المبن }
$$

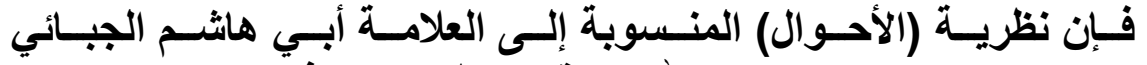

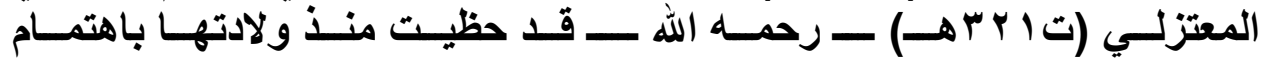

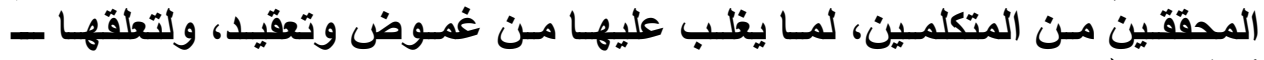

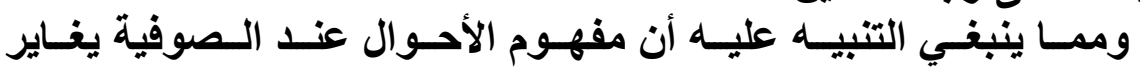

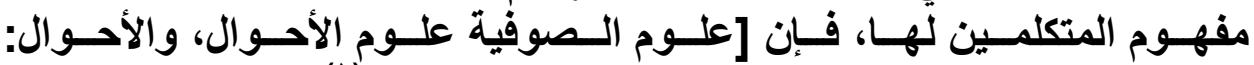

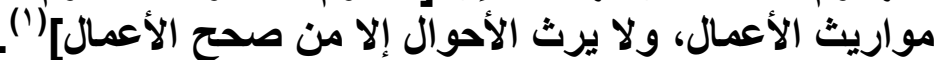

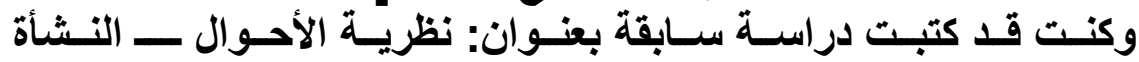

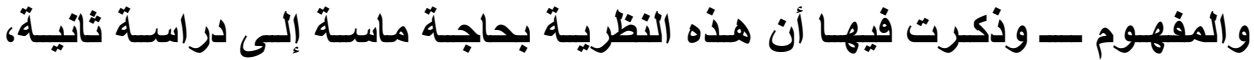

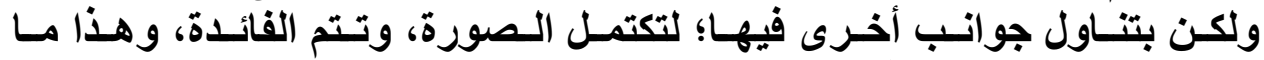

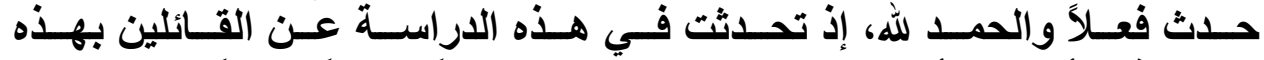

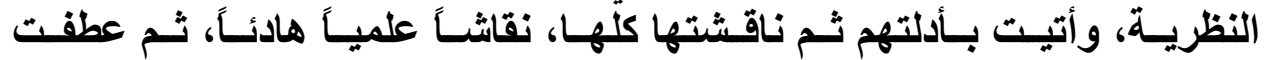

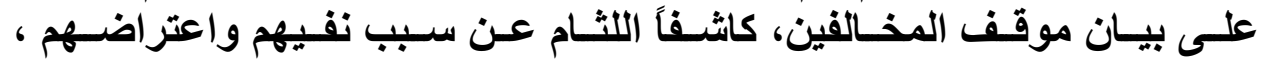

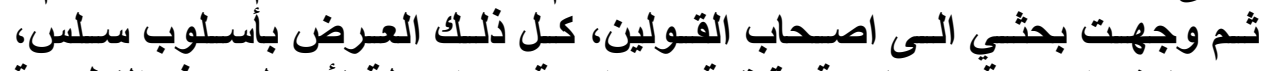

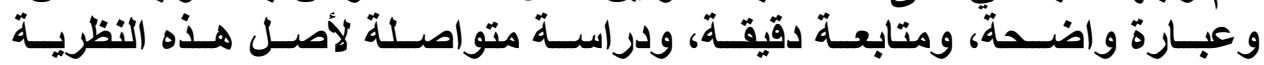

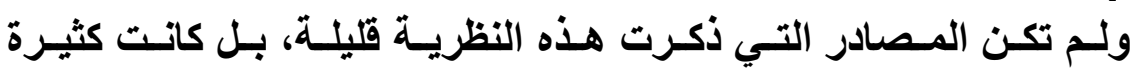

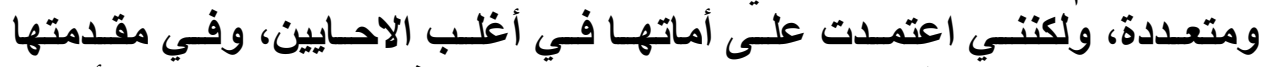

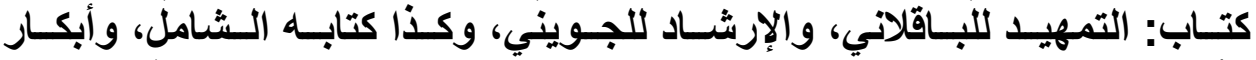

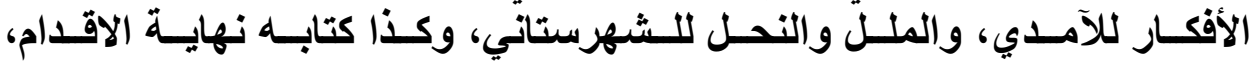

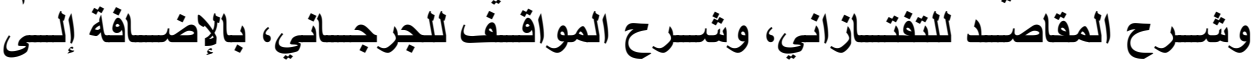

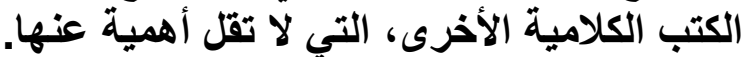

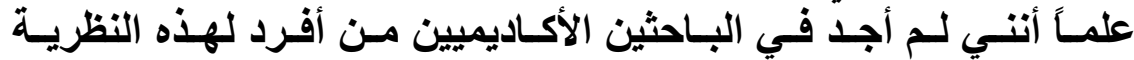

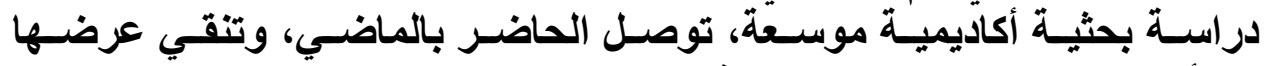
من ألفاظ التعقيا المنطقي، ليسهل فهيهـا، ويعم نوصل الفعها.

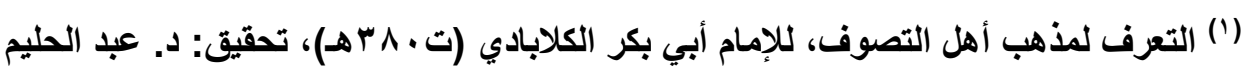

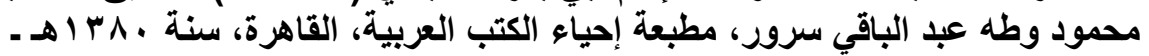


هذا وقث جاء البحث في ثلاثة مباحث رئيسة:

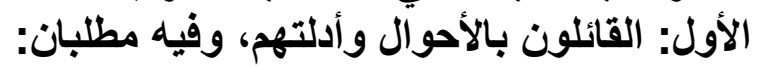

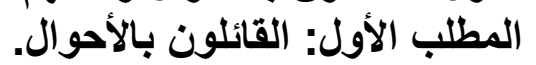
المطلب الثاني: أدلة القائلين بالأحوال ومناقتشتها.

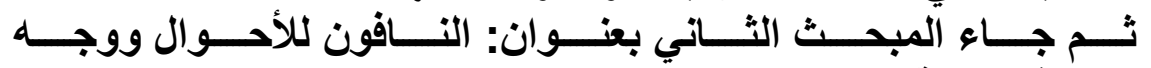
اعتراضهم، وفيه ثلاثة مطالب:

الأول: رأي المعتزلة ولئة ووجه اعتراضهم. الثاني: رأي الامامية ووجه الأية اعتر اضهم.

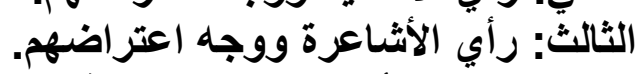

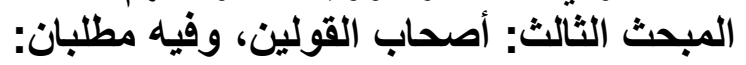

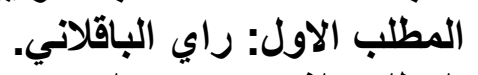

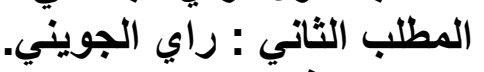

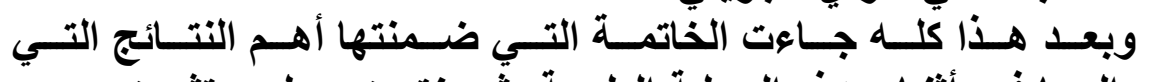

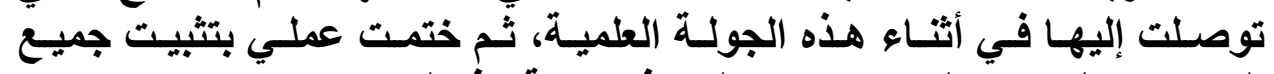

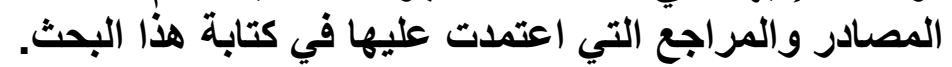

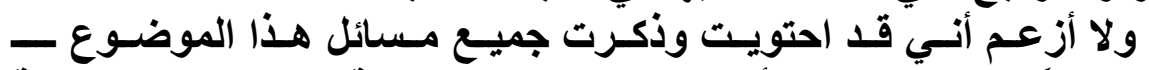

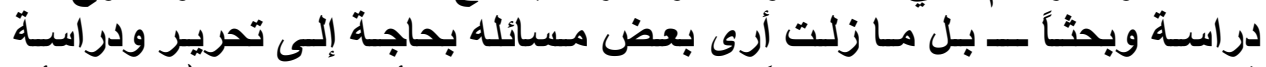

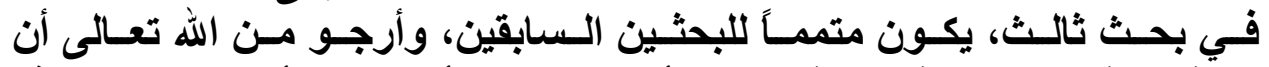

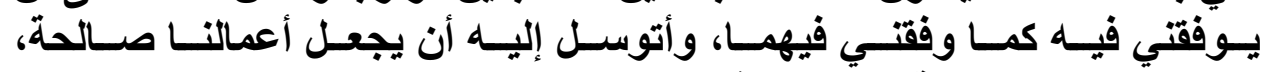

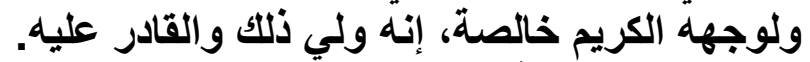

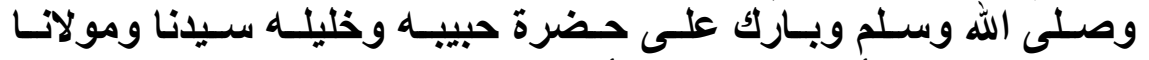

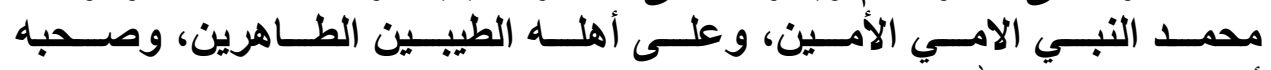
أجمعين، والحمد الله رب العالمين.

\author{
الباحث

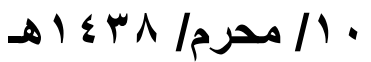

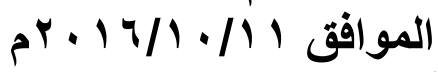 \\ في بغداد دار العلم والعلماء
}




\section{المبحث الأول}

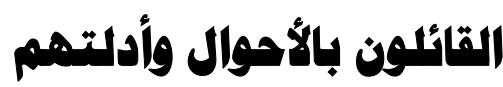

\section{المطلب الأول}

\section{القائلون بالأهوال}

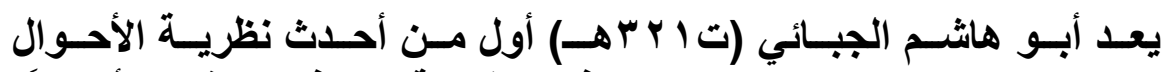

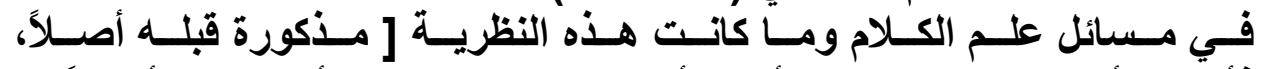

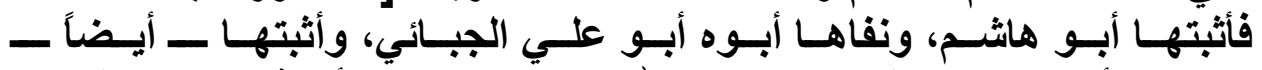

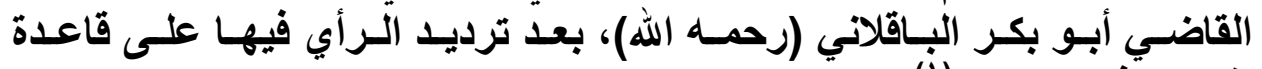

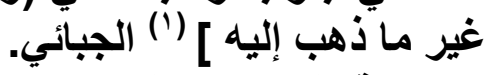

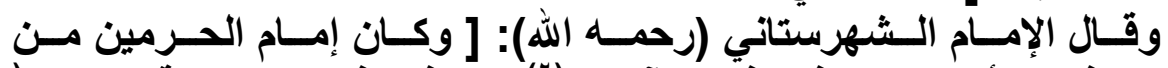

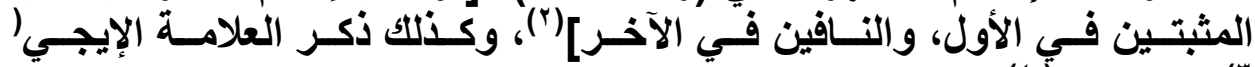

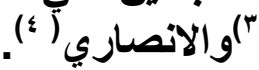

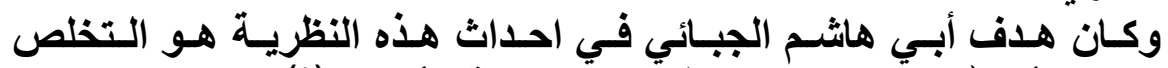

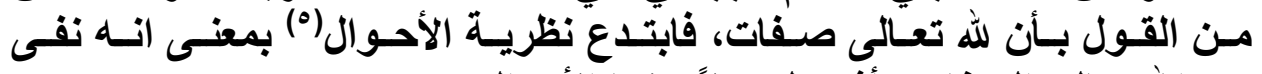

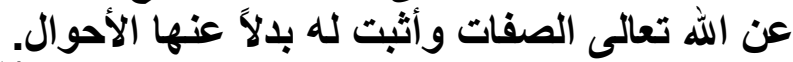
ولقد تابعه على ذلك بعض متأخري المعتزلة (") بخلاف قدمائهر

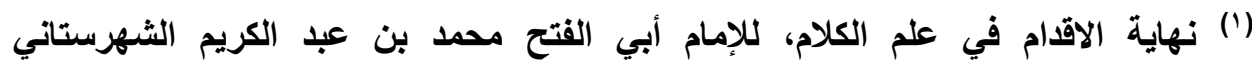

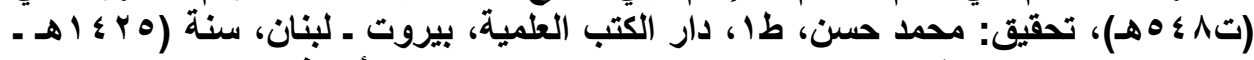

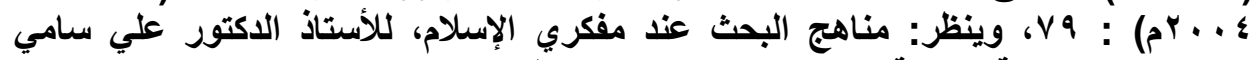

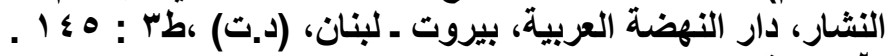

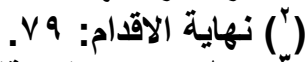

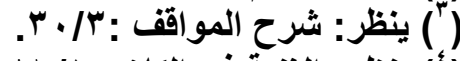

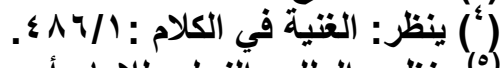

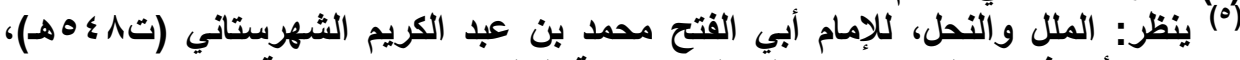

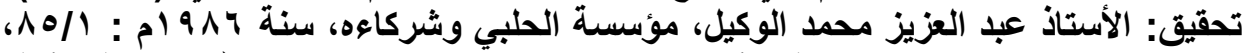
وينظر: الباقلاني وآراؤه الكلامية، لأستانتا الدكتور محمد رمضان عبد الله، مطبعة الأمة،

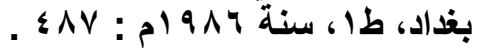
(") ينظر: أبكار الأفكار في أصول الدين، للإمام أبي الحسن علي بن محمد بن سالم الآمدي

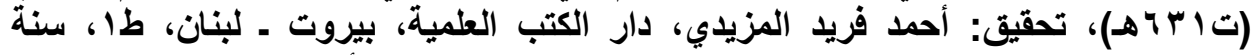

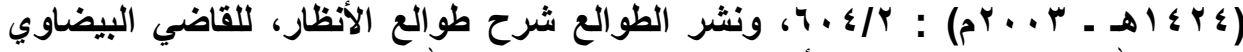

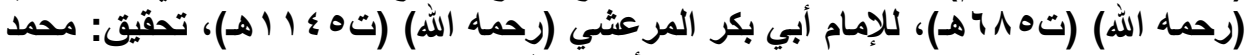

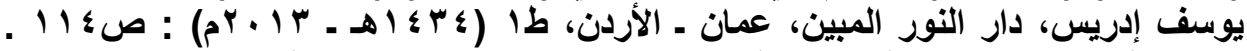
والوسيلة في شرح الفضيلة ، للعلامة الثيخ عبد الكريم المدرس، مطبعة الارشناد، بذاد، طا، الها،

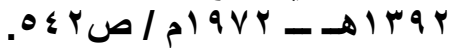




\section{الأين نفوا هذه النظرية وأنكروها"')}

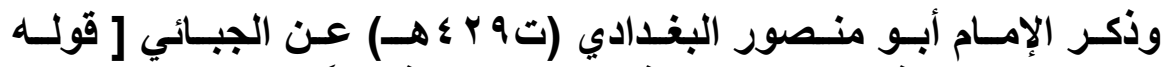

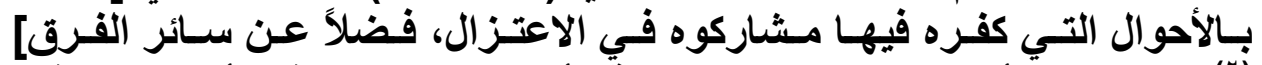

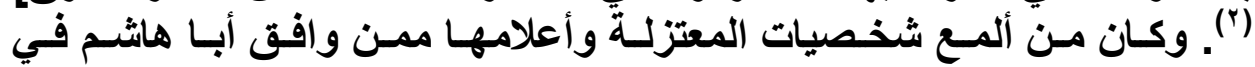

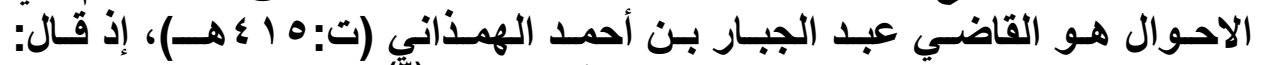

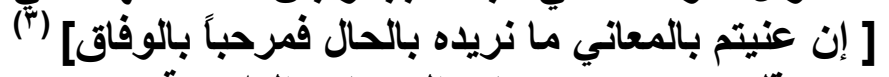

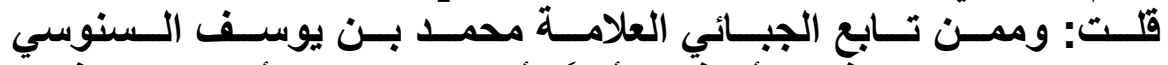

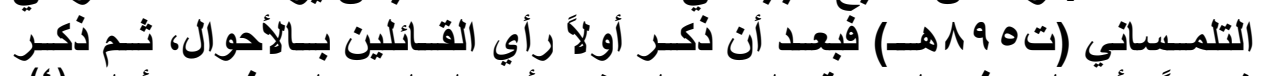

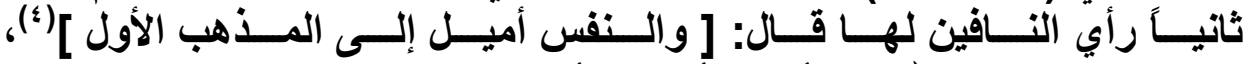

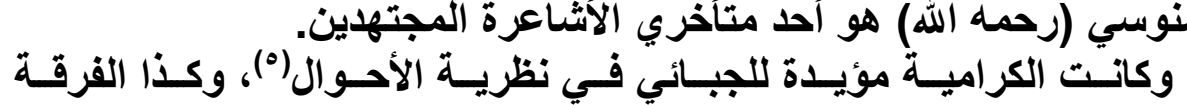

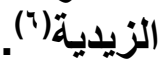

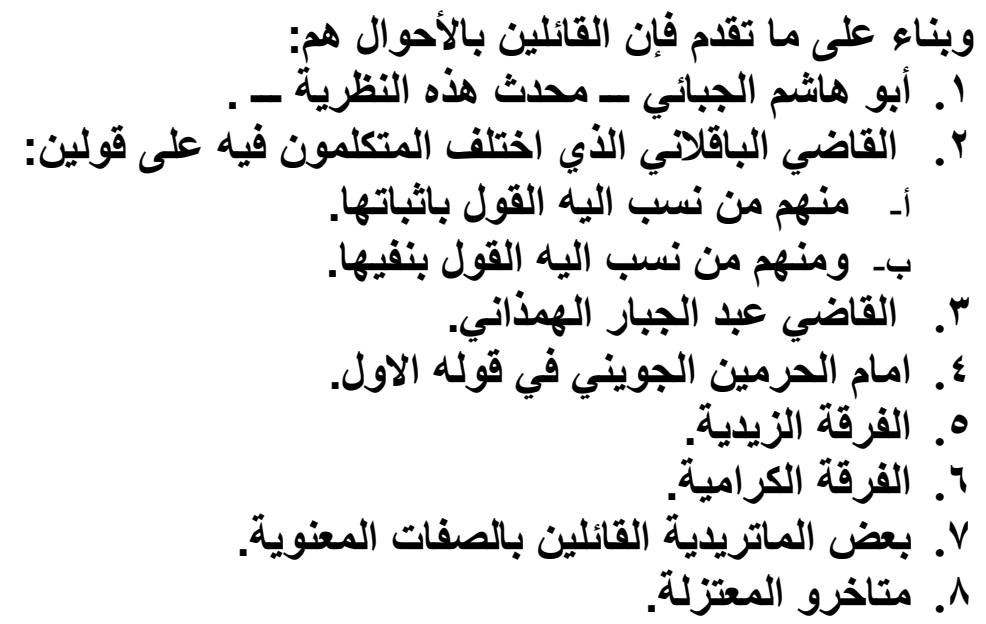

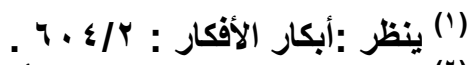

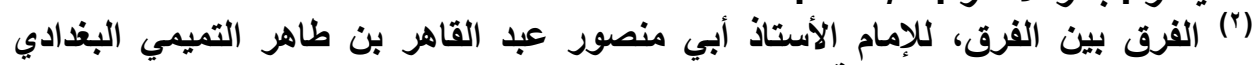

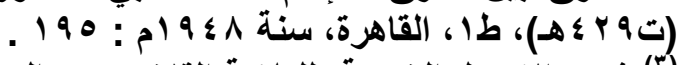

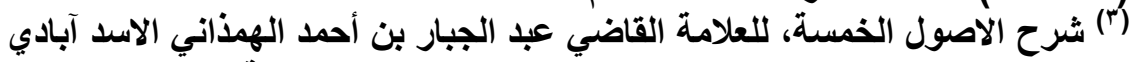

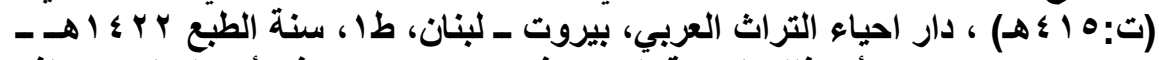

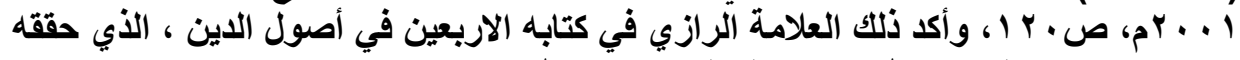

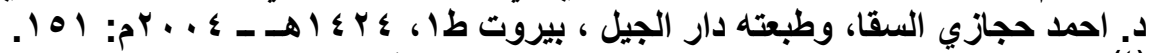

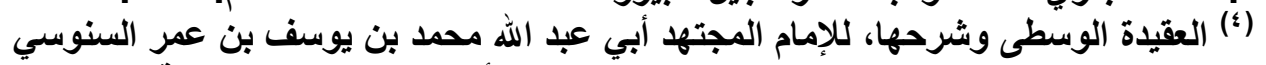

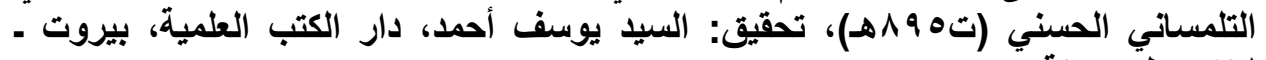

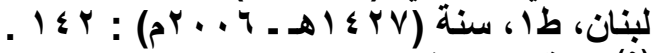

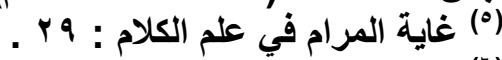

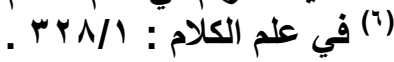




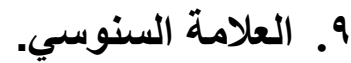

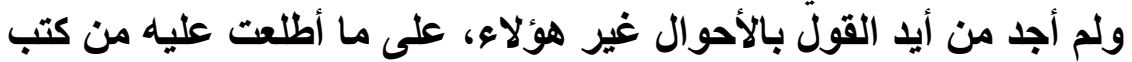

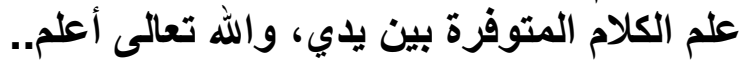
المطلب الثانبي

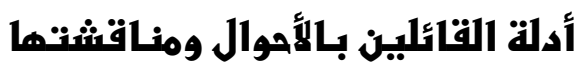

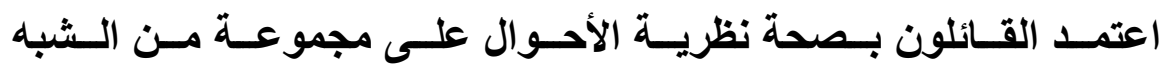

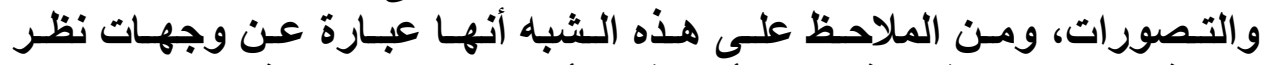

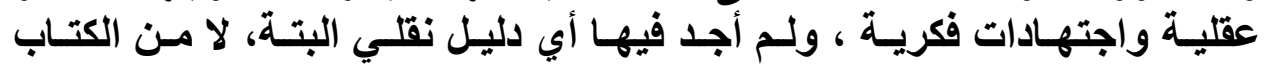

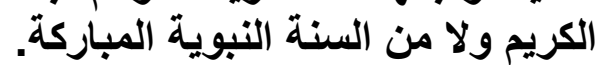

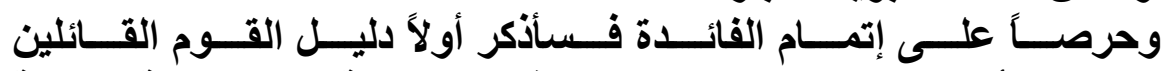

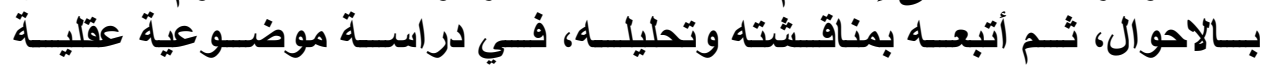

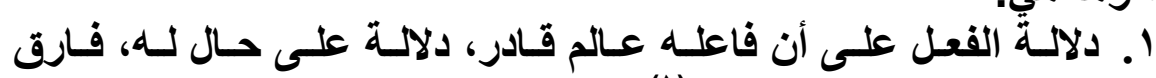

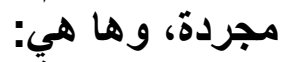

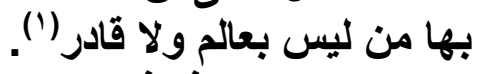

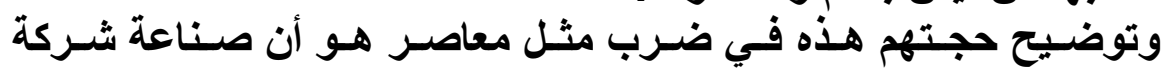

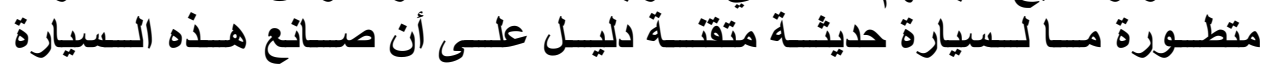

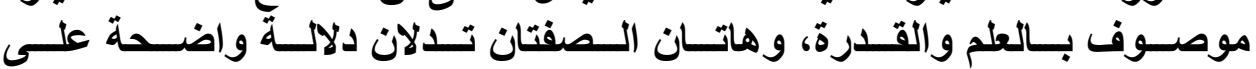

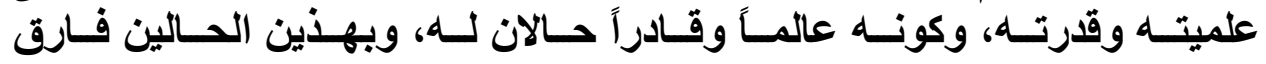

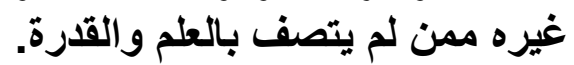

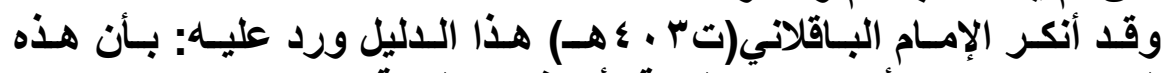

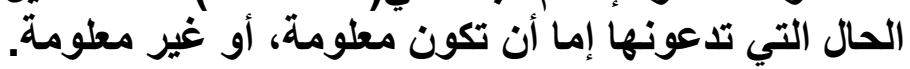

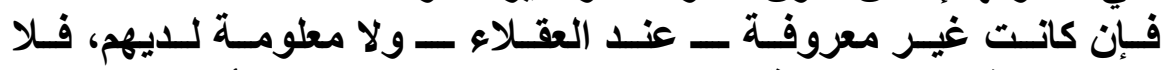

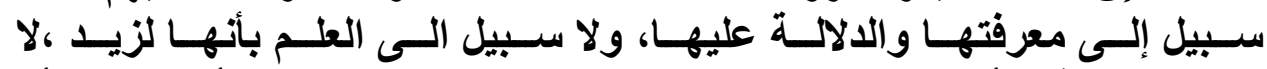

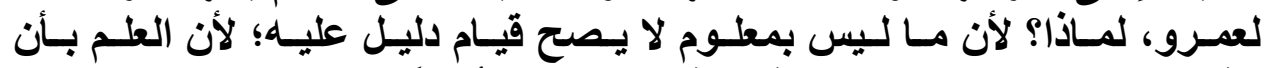

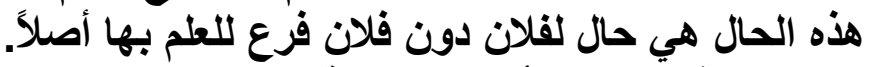

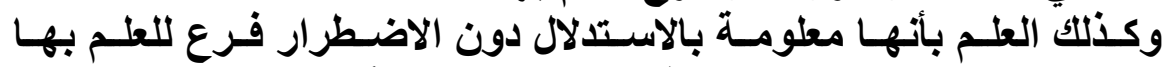

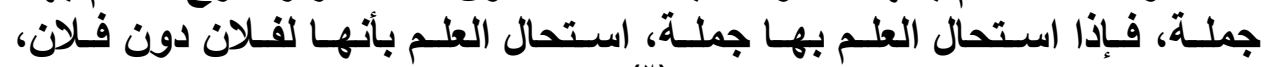

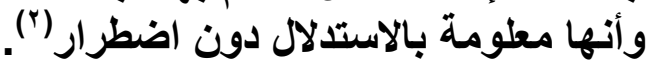

(') ينظر: تمهيد الأوائل وتلخيص الدلائل، للإمام العلامة القاضي أبي بكر محمد بن الطيب الباقلاني

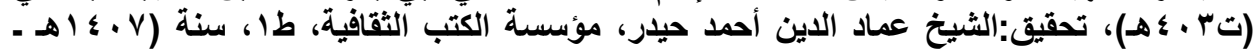

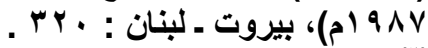

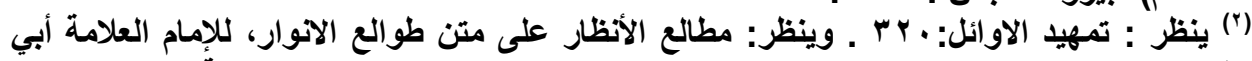

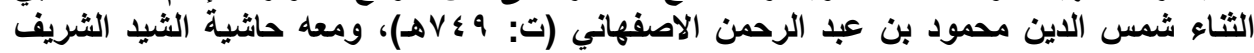

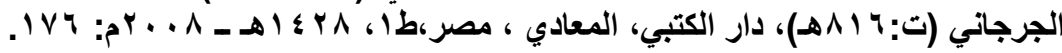




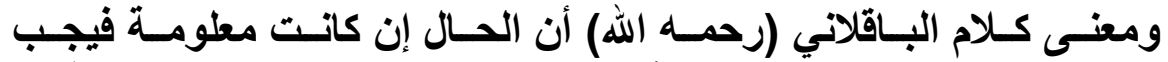

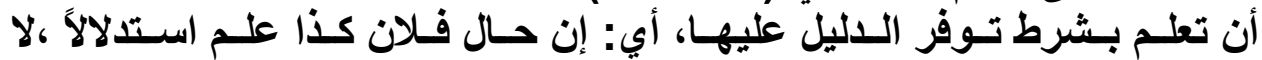

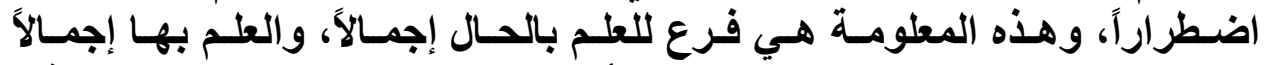

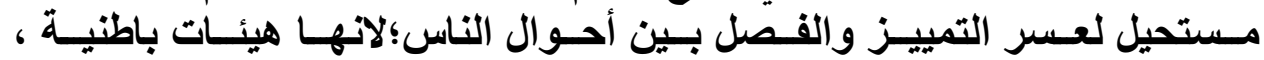

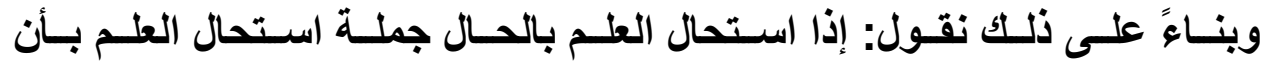

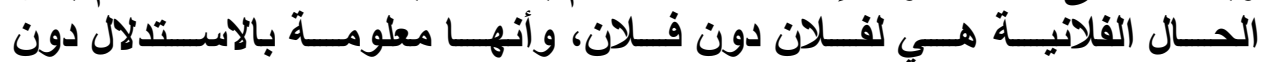

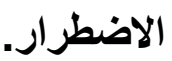

r. وقـالوا ايـضا: إن نفس مسن لـه الحسال معلومـة علـى الحسال. قــال

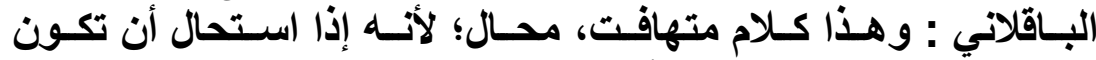

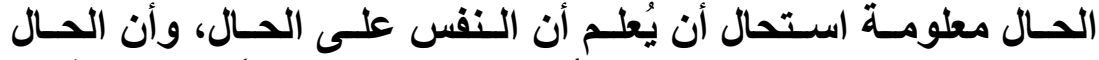

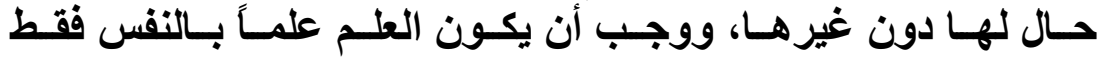

دون الحال (1).

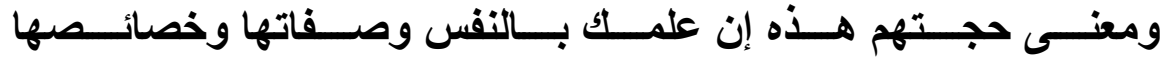

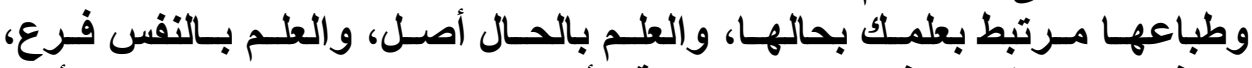

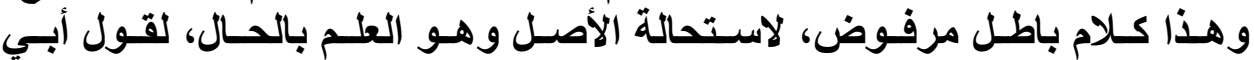

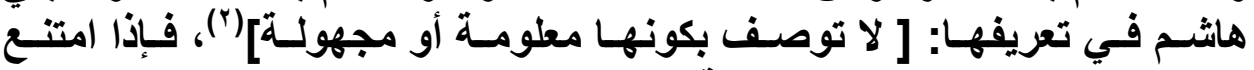

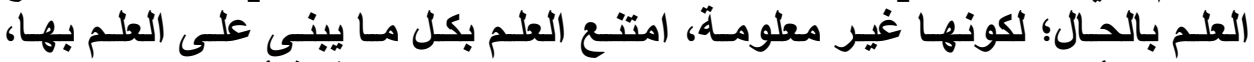

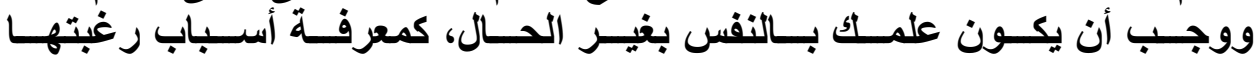

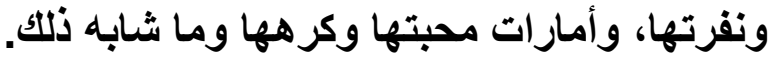

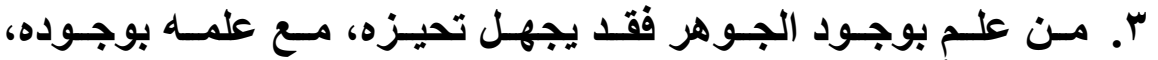

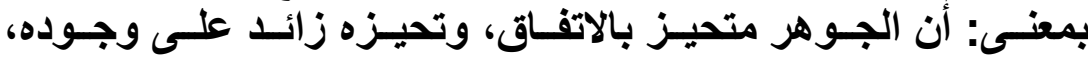

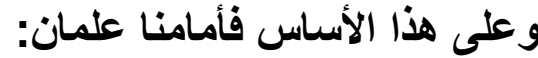

$$
\text { ب ـ ـ العلم بوجيز لـ الجيز الجوهر. }
$$

وهذان العلمان ليسا علماً واحداً؛ وذلك لسبينين: أولاً: لجواز ثبوت العلم بوجود الجوهر مع الجهل بتحيزه.

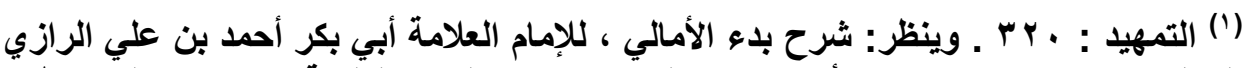

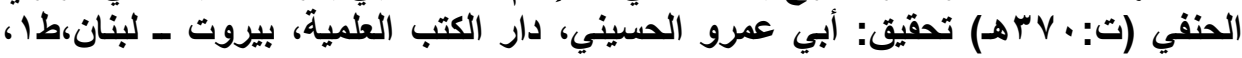

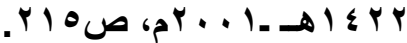

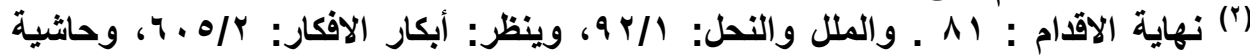

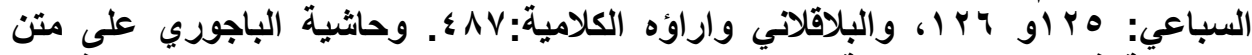

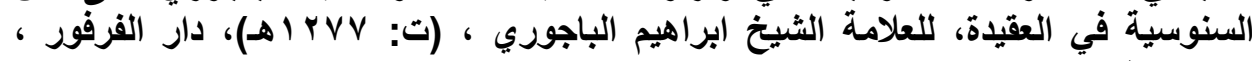

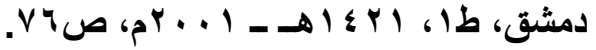


وثانياً: لـو كـان العلـم بـالتحيز هو عين العلـم بـالوجود، لاسـتحال ارتفاعـه مـع

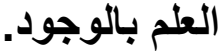

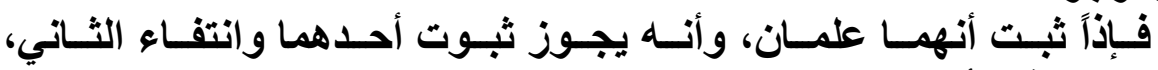
ونستنتج من ذلك أمرين:

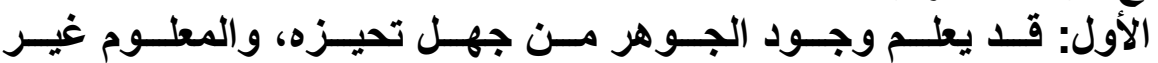

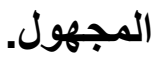

الثاني: العلم بوجود الجوهر بتقدير الوجود ضروري،

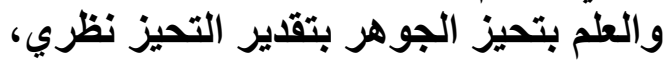
والمعلوم بالضرورة هو غيز المعلوم بالنظر والاستدلال.

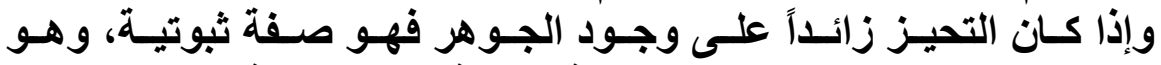

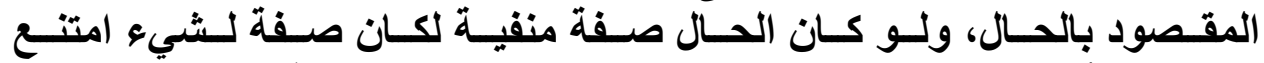

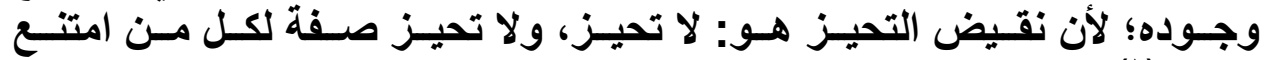

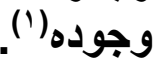

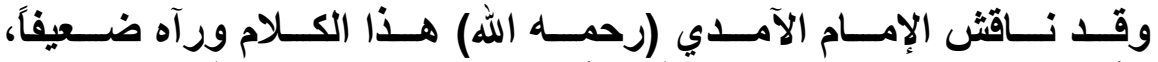

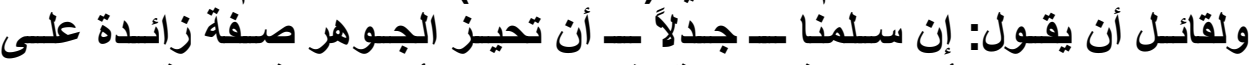

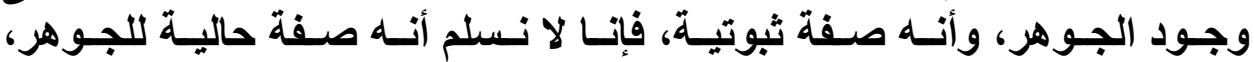

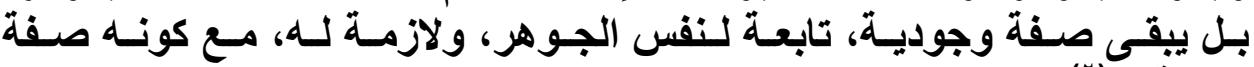

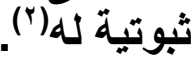

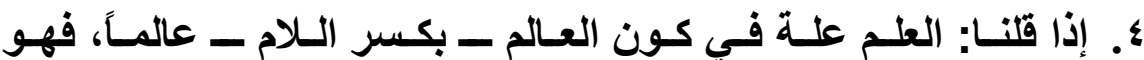

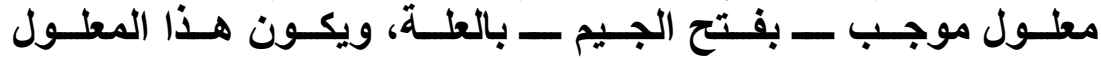

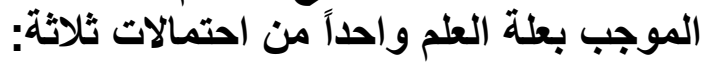

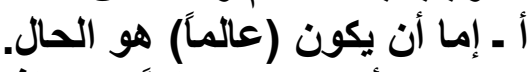
ب - وإما أن يكون (عالماً) هو الذات التون التي قام بها التها العلم.

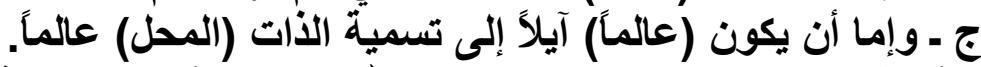

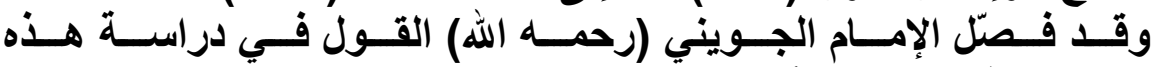

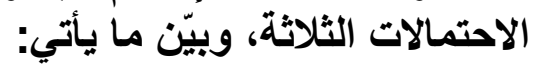
أ. إن كان التفسير الصحيح في الاحتمال الأول، كان ذلتك هو الحال.

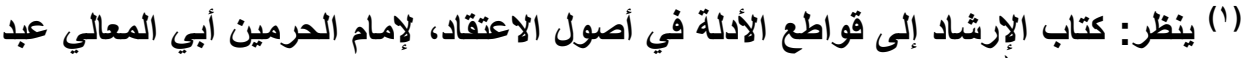

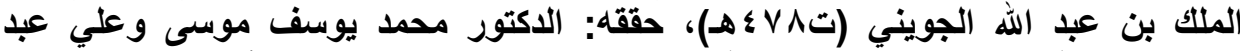

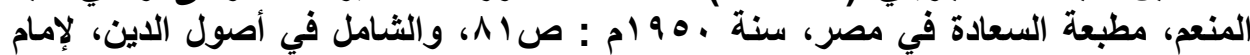

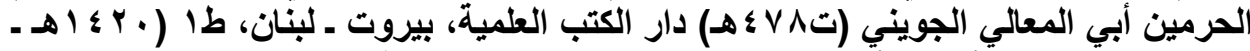

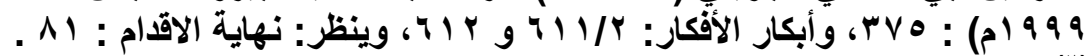




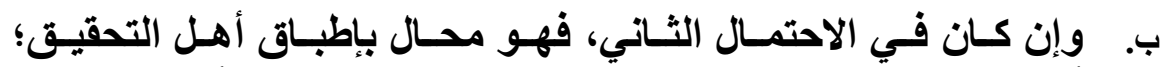

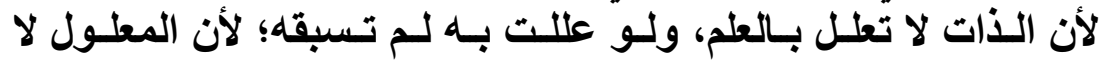

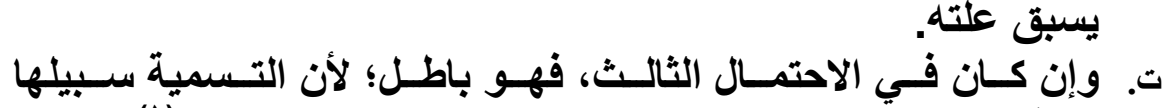

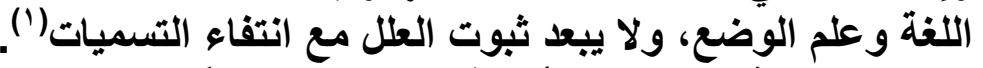

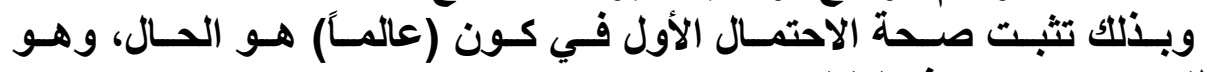

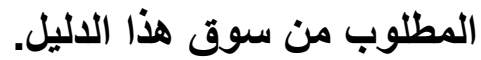

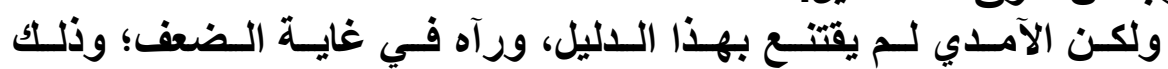

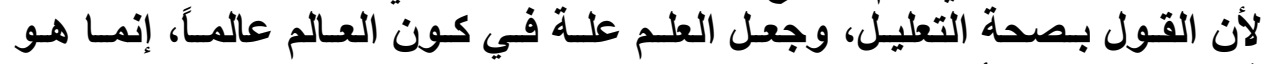

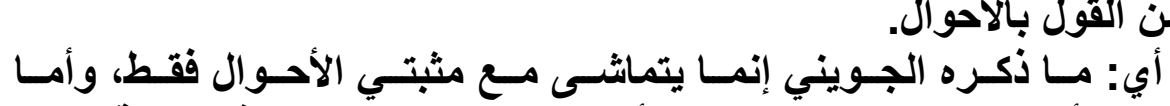

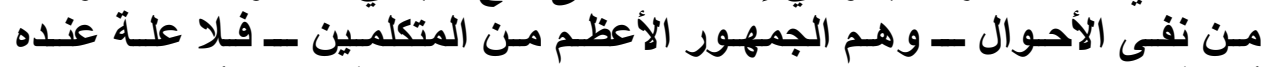

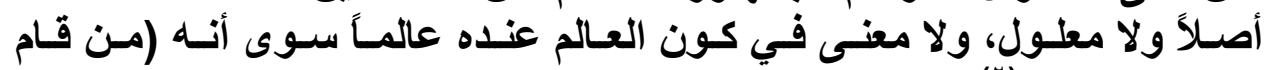

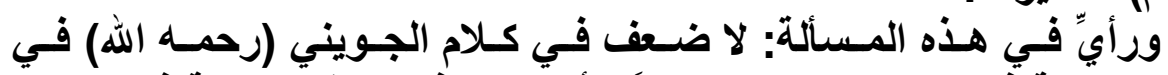

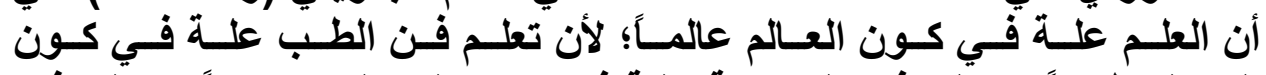

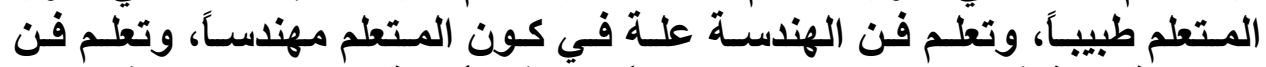

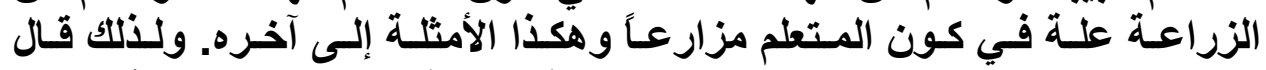

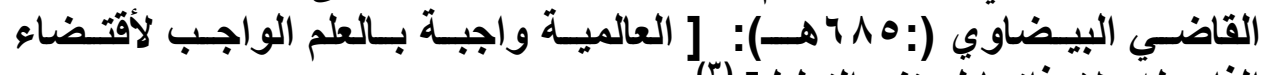

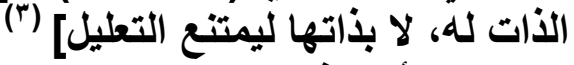

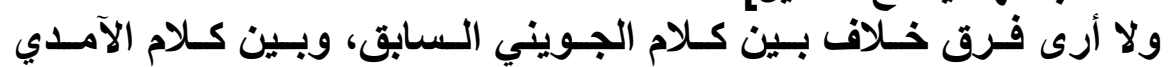

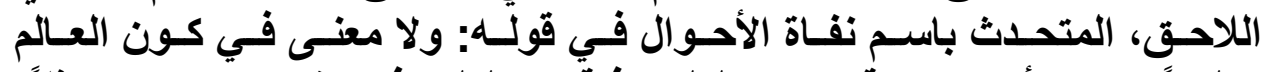

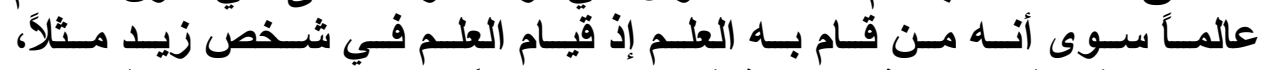

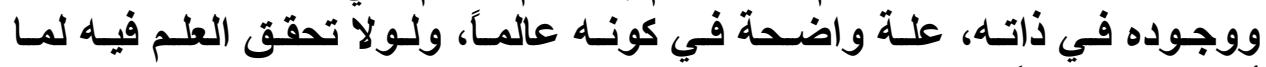

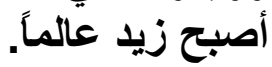

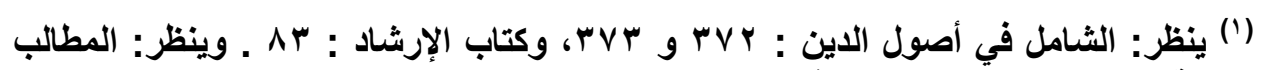

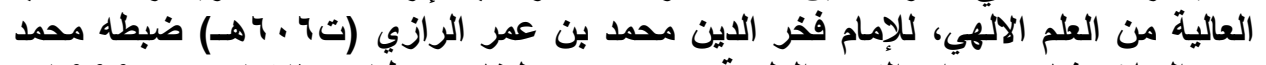

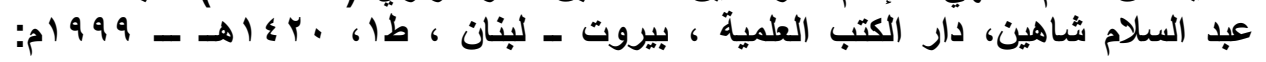

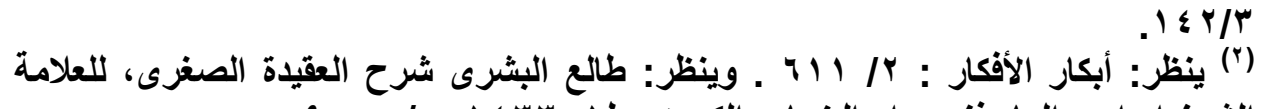

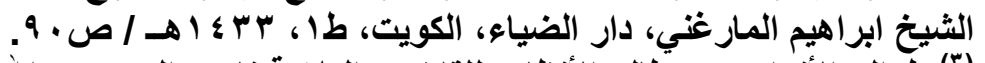

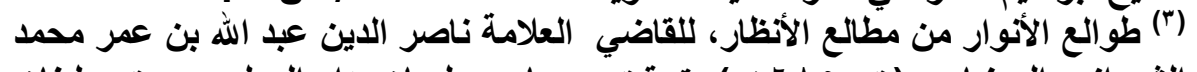

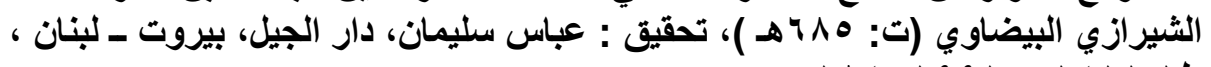




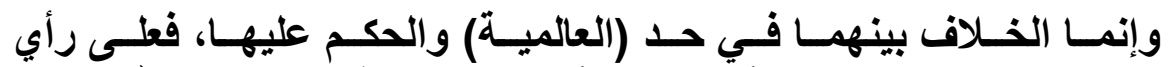

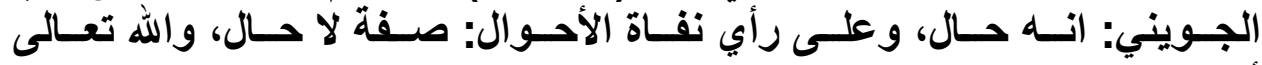

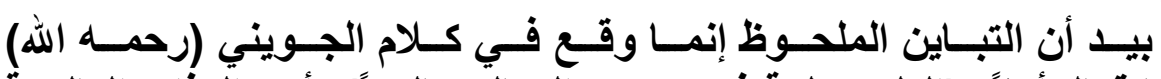

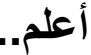

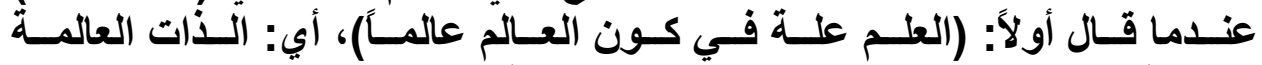

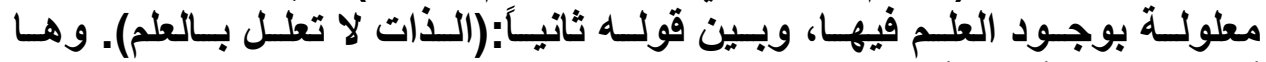

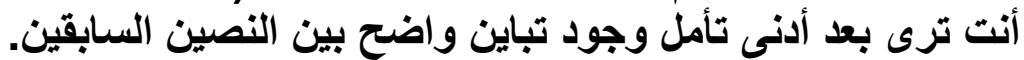

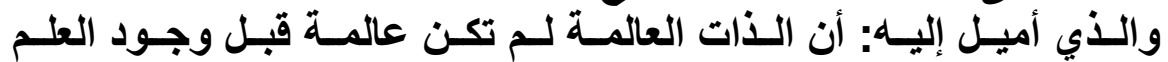

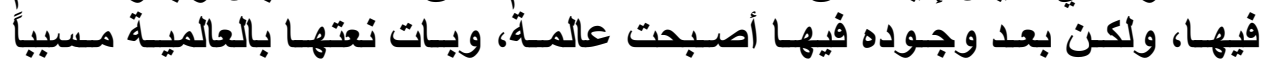

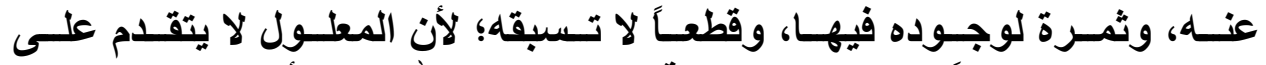

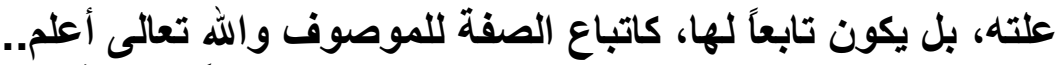

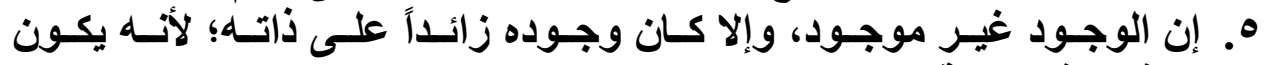

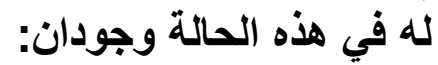

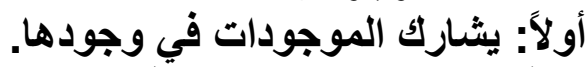
ثانياً: يمتاز عنها بخصوصيَّة هي ذاتهودئ.

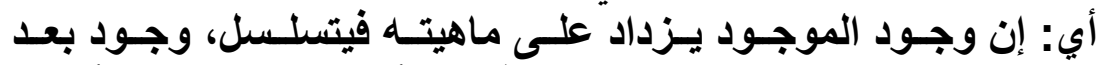

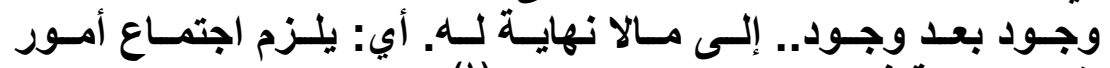

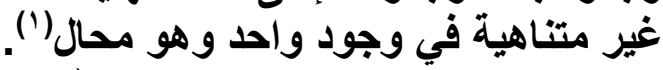

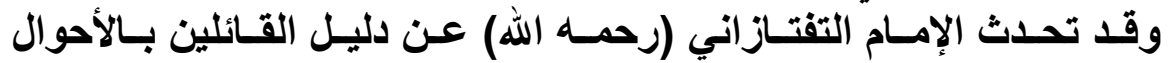

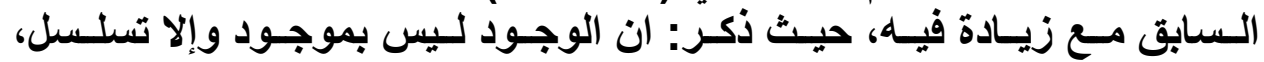

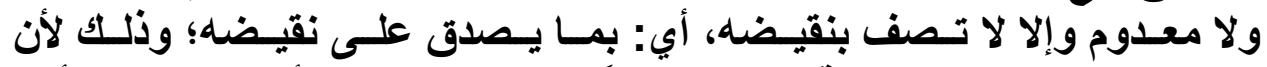

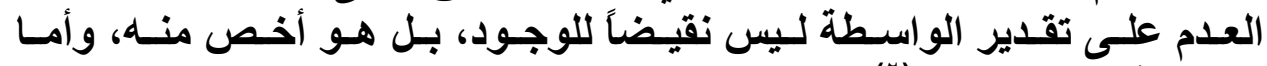

نقيضه فهو: اللا وجود (")

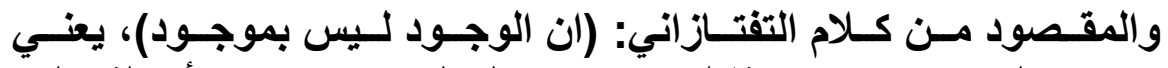

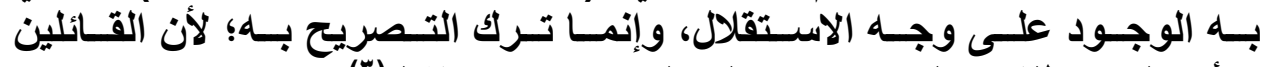
بالأحوال لا يطلقون الموجود إلا على الموجود بالاستقلال (").

(') ينظر: شرح السنوسية الكبرى، للعلامة أبي عبد الله يوسف بن عمر السنوسي، علق عليه

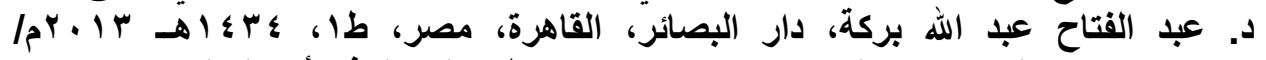

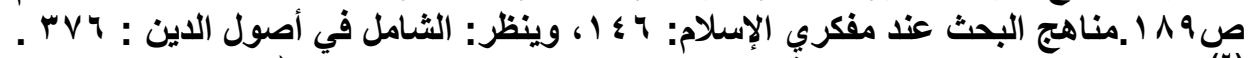

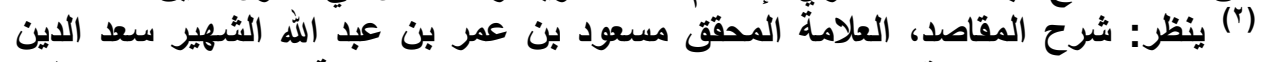

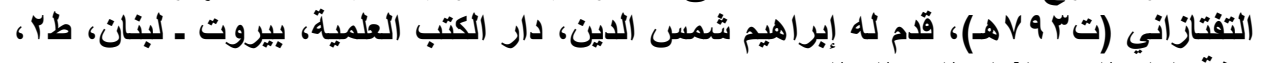
سنة

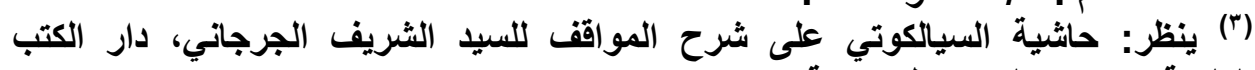

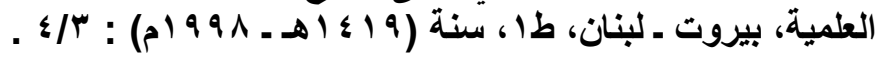




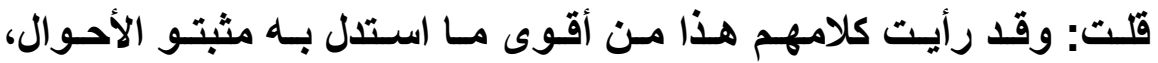

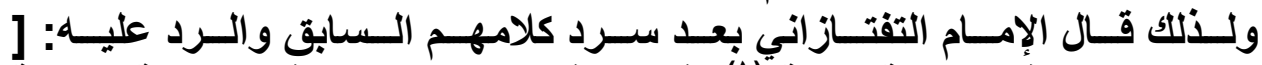

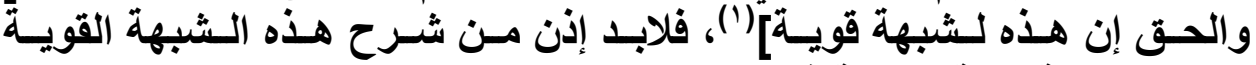
بعبارة رصينة قوية مفصلة فنقول فئول

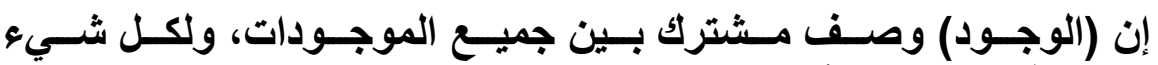

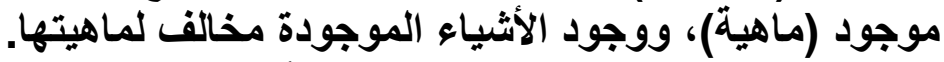

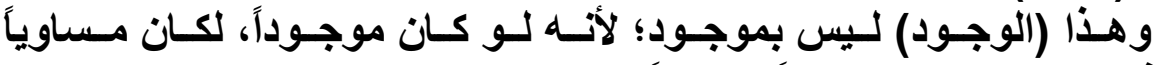

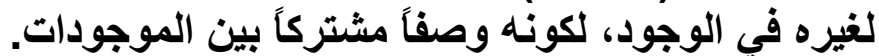

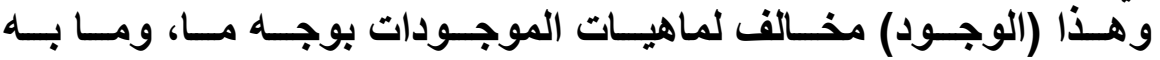

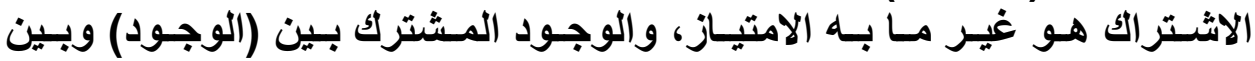

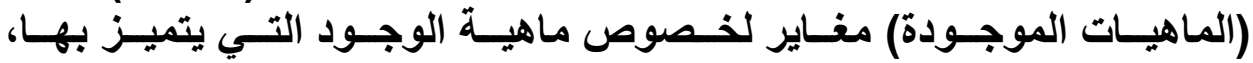
فيكون للوجود وجود آخر، ويزيد وجوده ملئ ملى ماهيته ويلزم التسلسل.

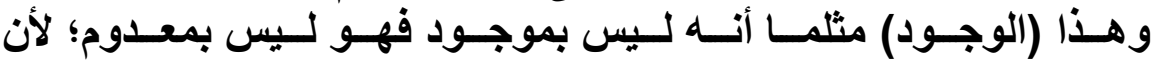

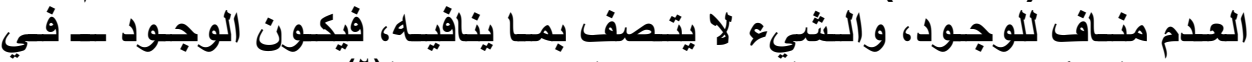

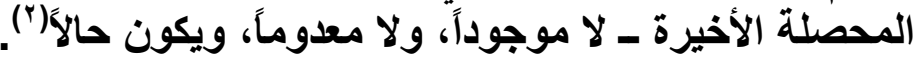

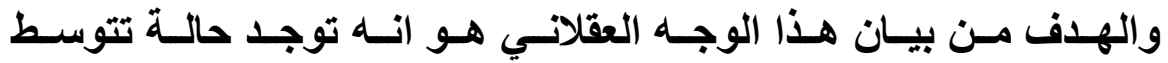

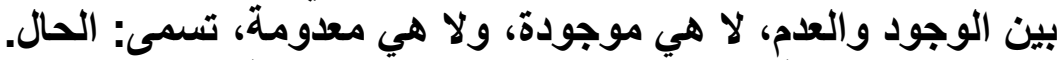

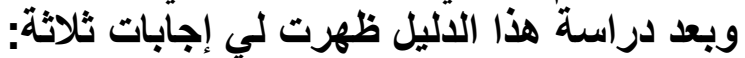

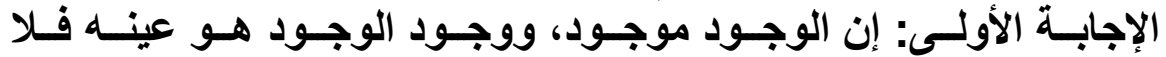

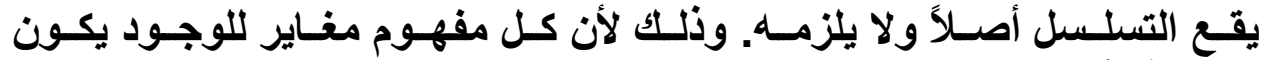
موجوداً بأمر زائد يضاف إليه، فيلزم عندائذٍ التسلسل. لاندل

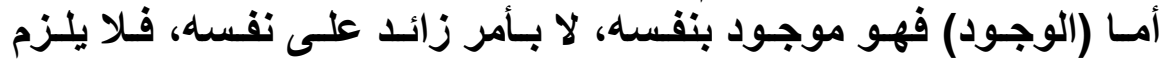

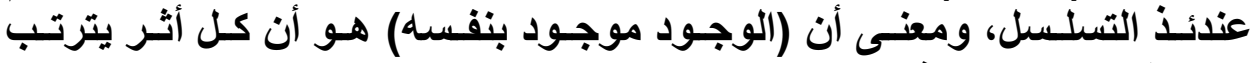

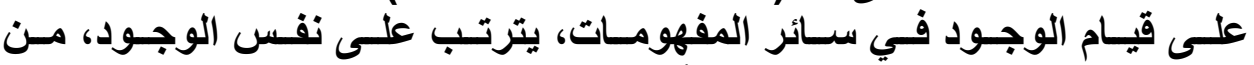

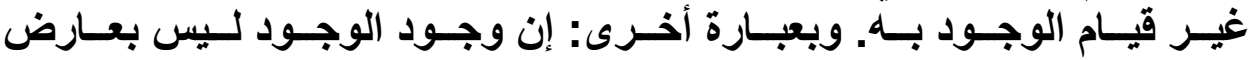

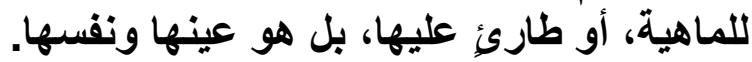

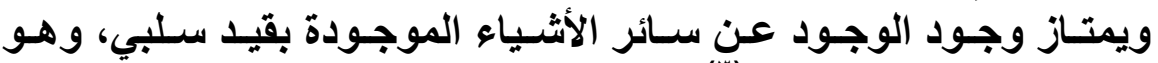

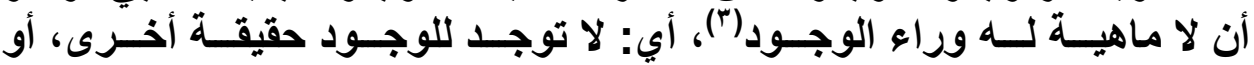

$$
\text { (r) }
$$

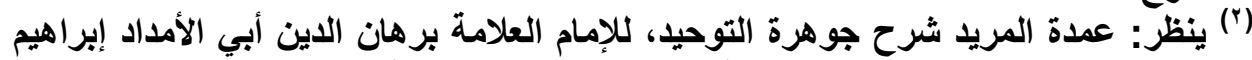

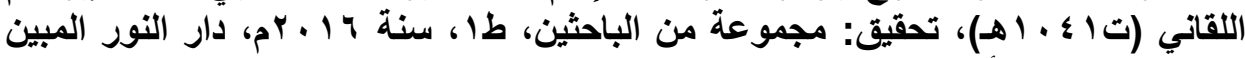

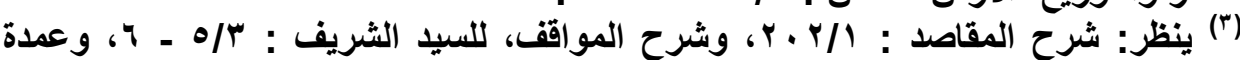

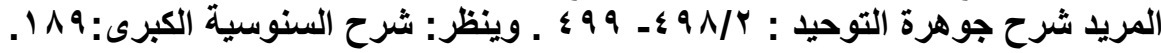


مفهـوم آخـر، يـضـاف إليـه غيـر الـذي ذكرنــاه، وهـو أن وجـوده أصسيل في نفسه، وليس طارئًاً عليه.

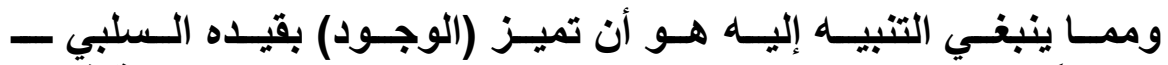

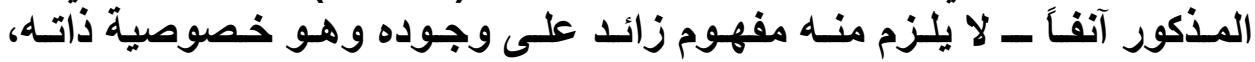

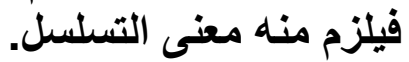

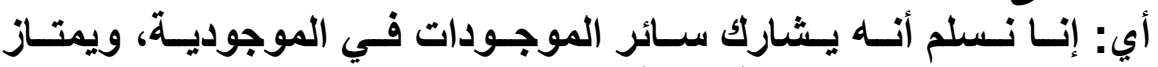

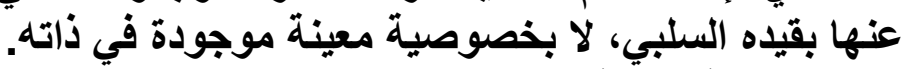
الإجابة الثانية: إن النية الوجود معدوم.

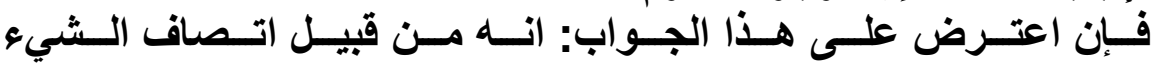
بنقيضه، كما يقال مثلاً: الوجود عدم، أو الموجود معدوم؟

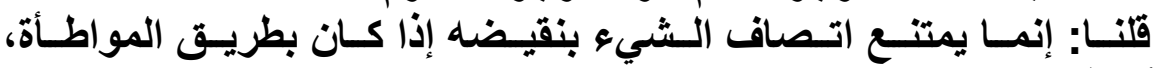

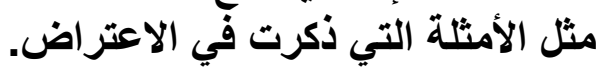

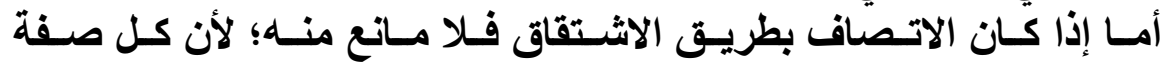

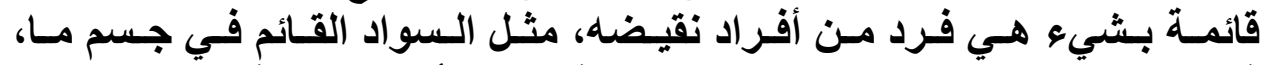

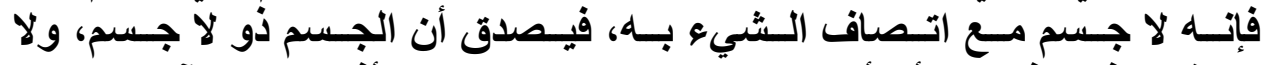

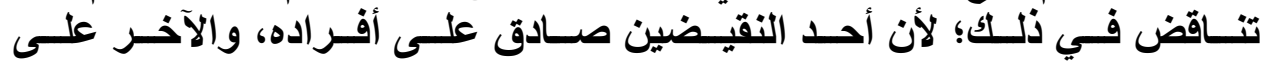

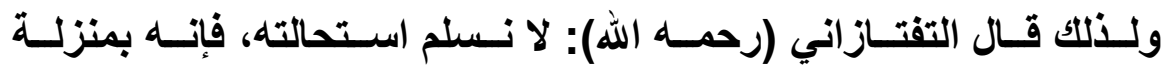
مفهومه.

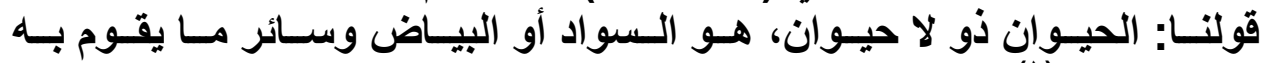

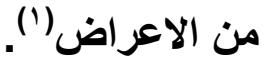

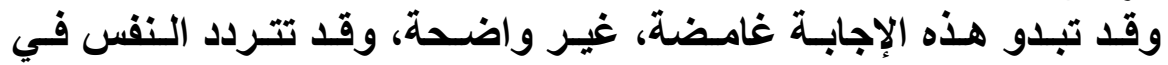

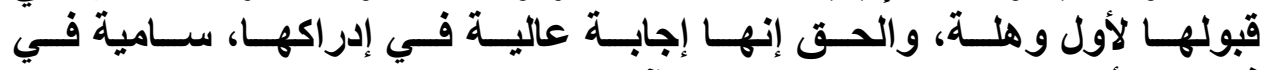
فكرها، وأوضحها لحضرتك والك بالمثالين الآتيين:

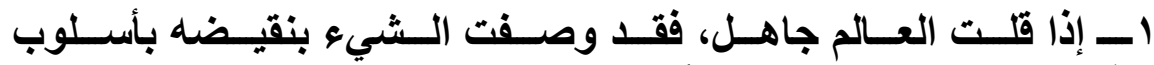

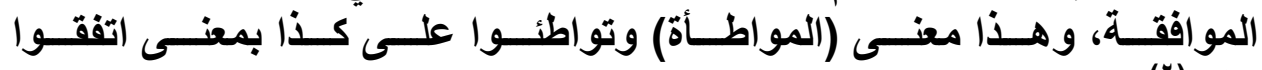
عليه(r). (r) r ـ وإذا قلت: العالم مجهول، فقد وصفت الثيء بنقيضه بأسلوب الاشتقاق الثاق

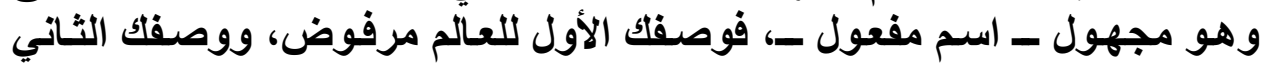

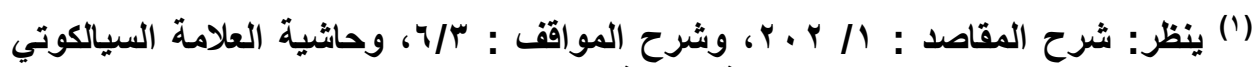

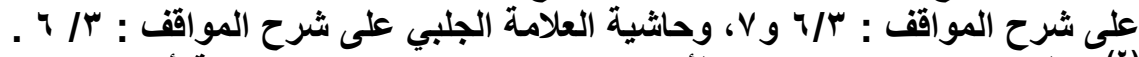

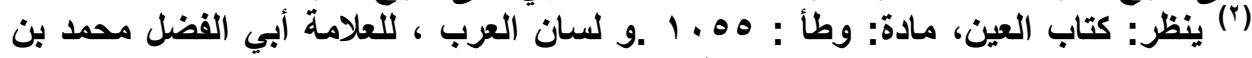

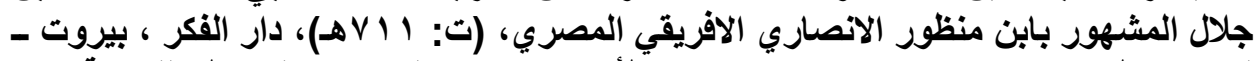

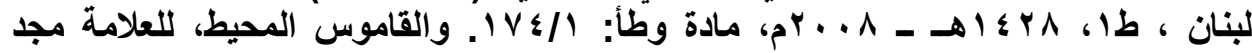

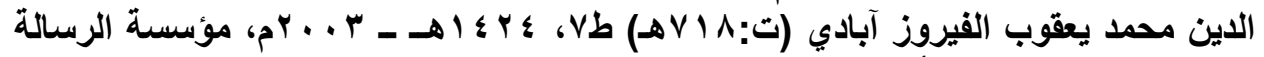

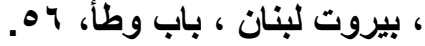


مقبول، ولذا فقولك: الوجود معدوم، هو غير قولك: الوجود عدم، أو الموجود

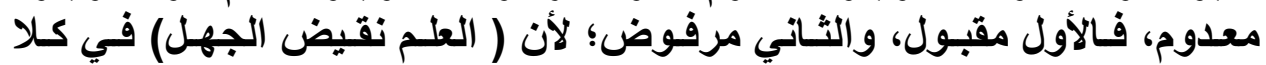

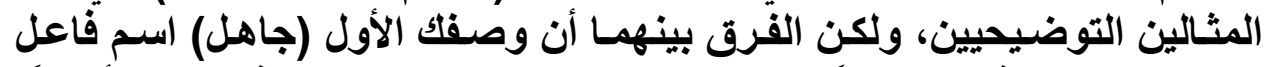

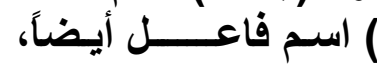
عوف (عال

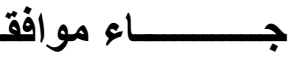

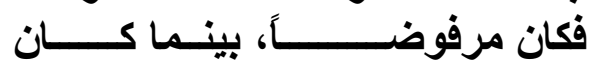

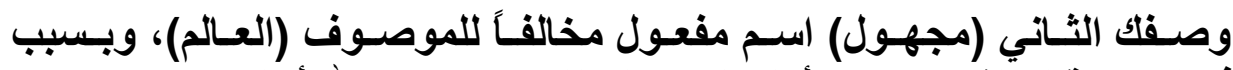
هذا التباين قبل الثثاني دون الأول؛ لحصول التهول الفرق بينهما والله أعلم..

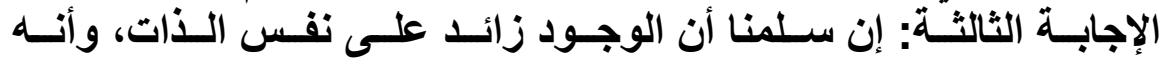

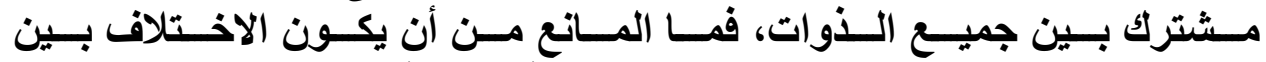

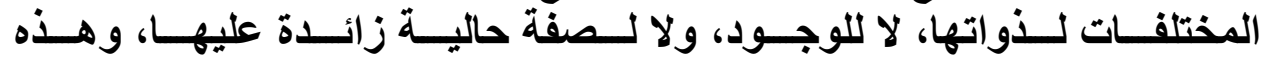

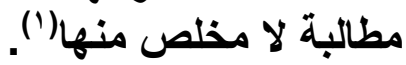

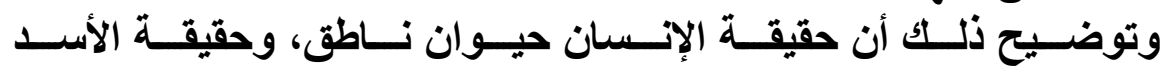

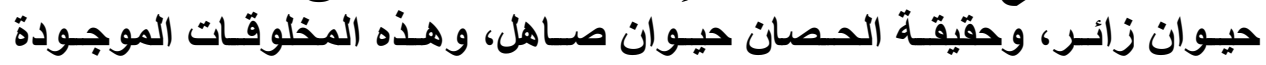

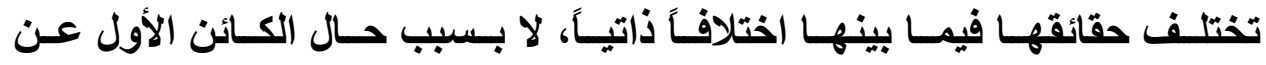

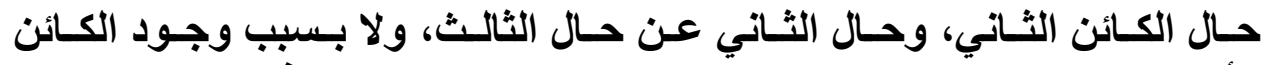

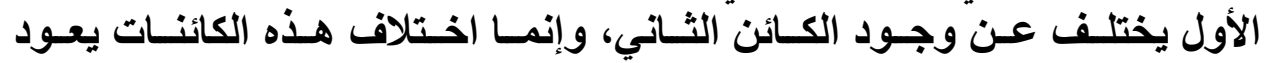

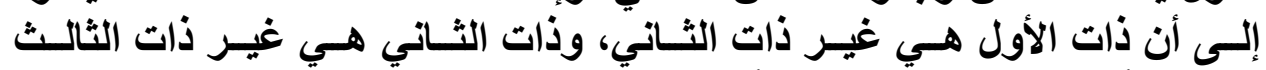
وهكا الأمر في سنائر الكائنات الأخرى فئ. 7. السواد مركب من جزأين:

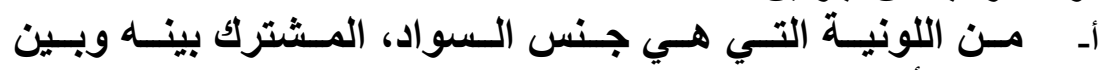
سائر الألوان.

بـ ومسن فصل يمتـاز بـه السوان السواد عـن سـائر الألـوان، وهـو قابـضية

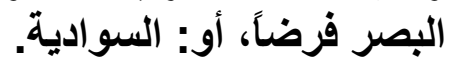

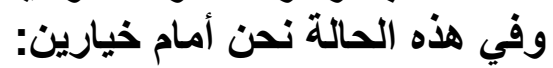

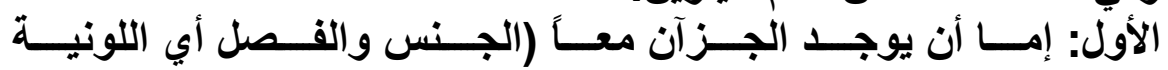

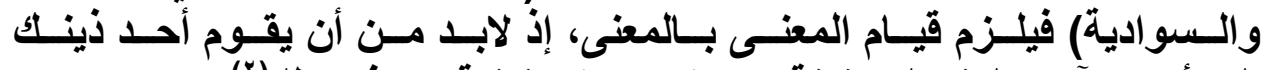

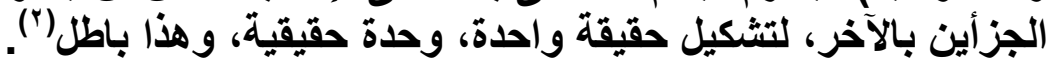

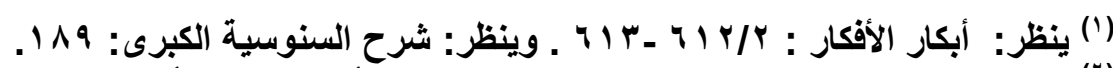

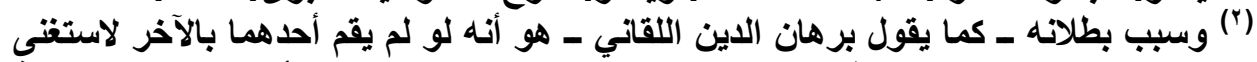

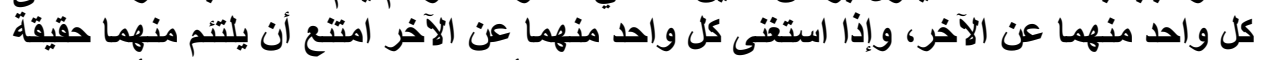

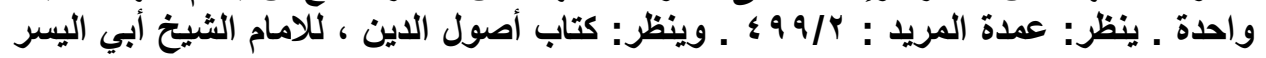

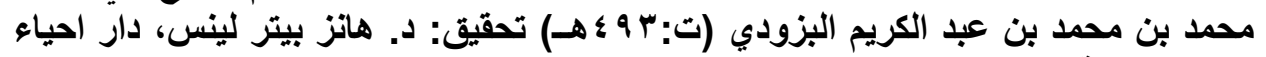

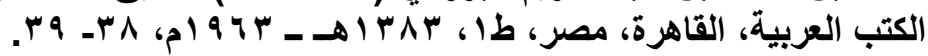


الثاني: وإما أن يعدما معاً، أو يعدم أحدهما فقط، فيلزم تقوم السواد ـ مع وجوداد

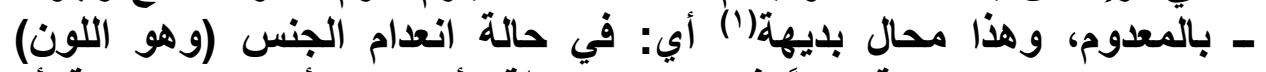

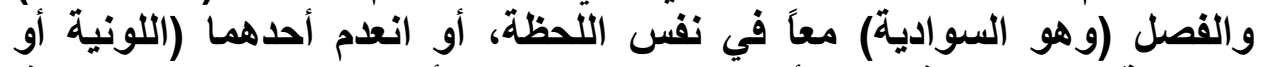

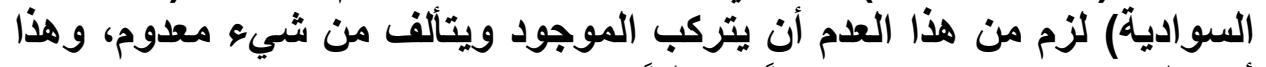

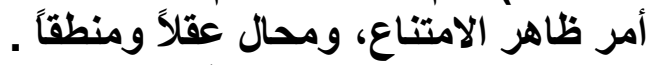

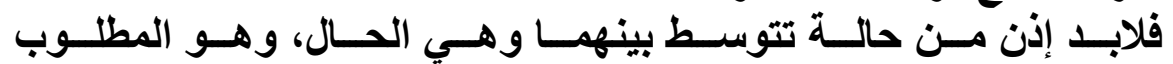

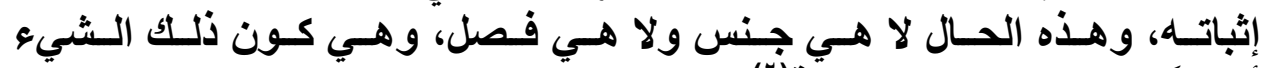

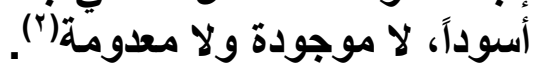

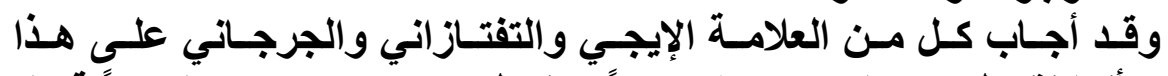

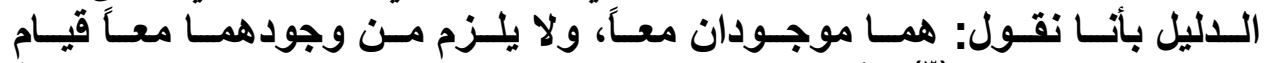

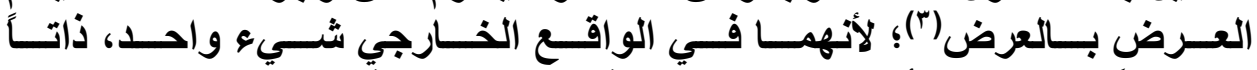

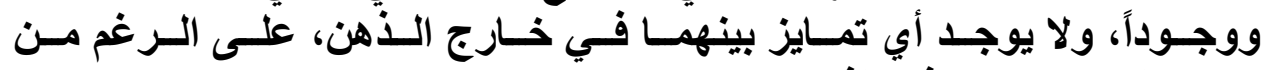
وجود التمايز بينهما في الأهن.

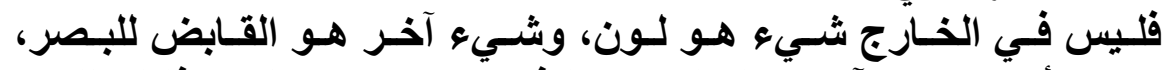

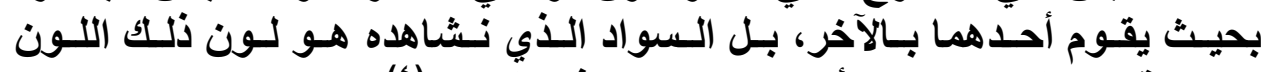

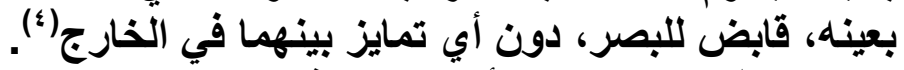

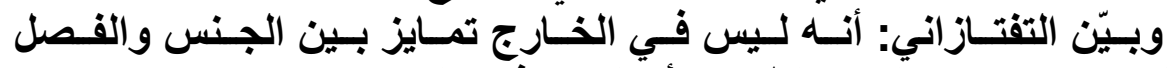

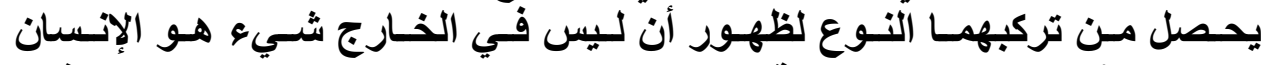

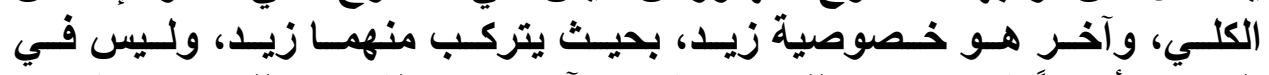

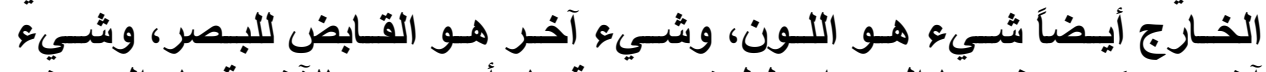

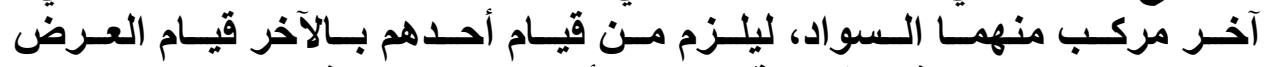

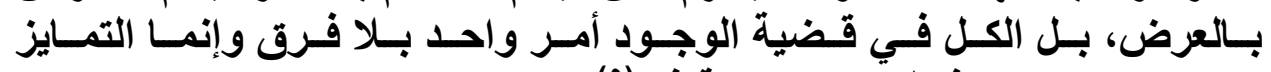

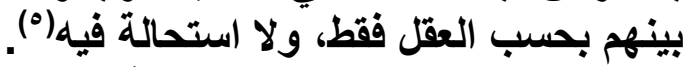

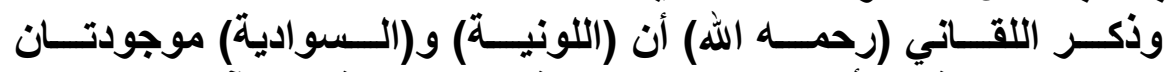

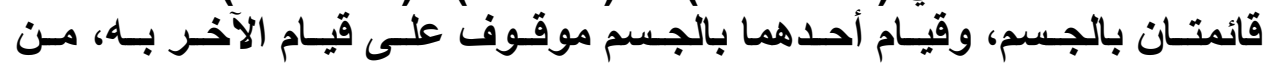

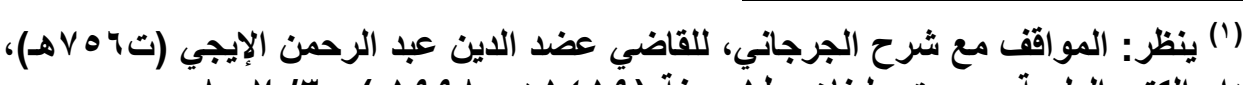

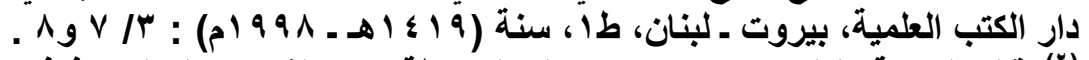

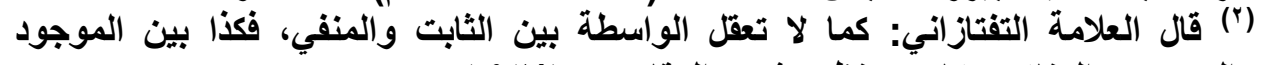

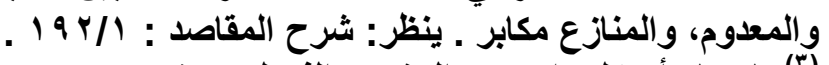

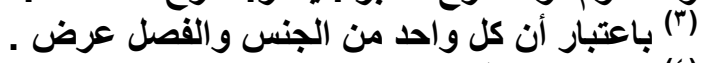

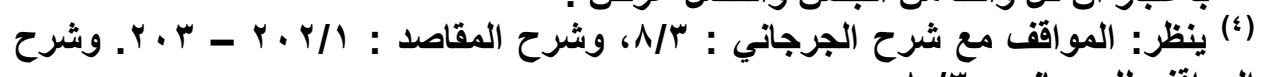

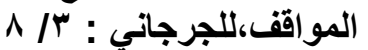

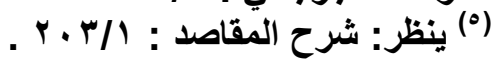




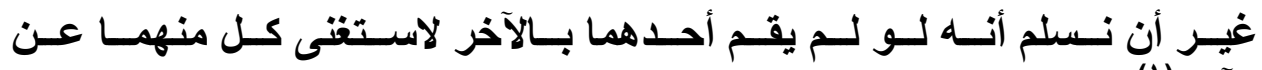

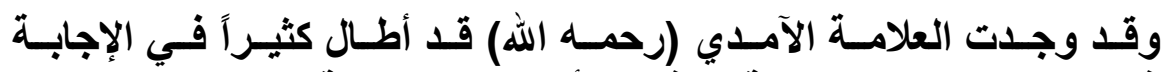

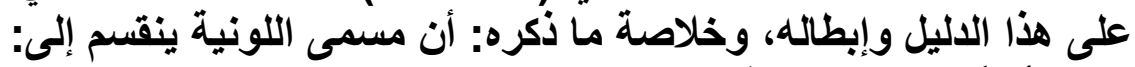
أولاً: كلي يشترك فيله كثيرون.

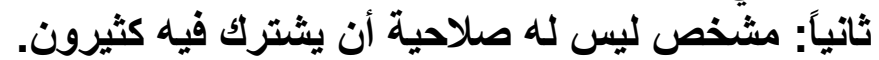

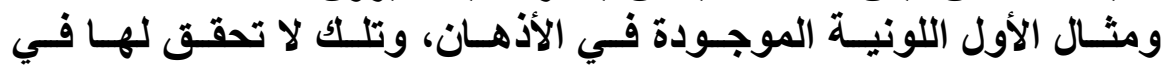

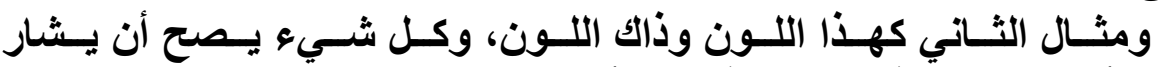

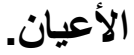

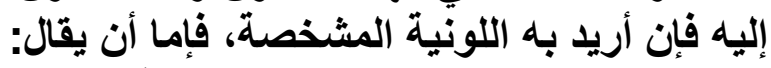

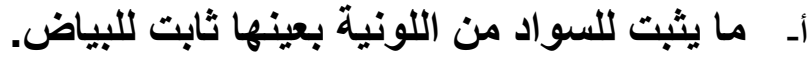

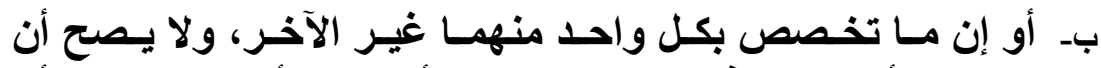

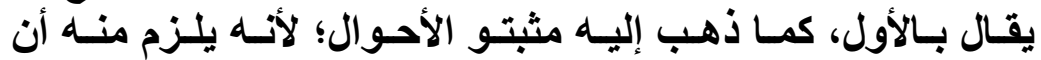

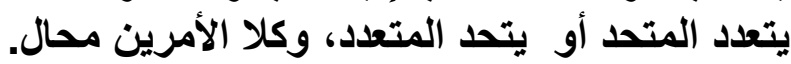

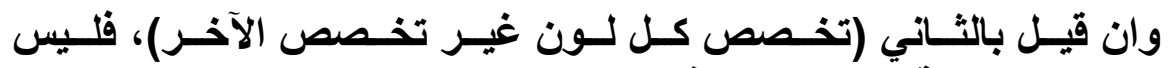

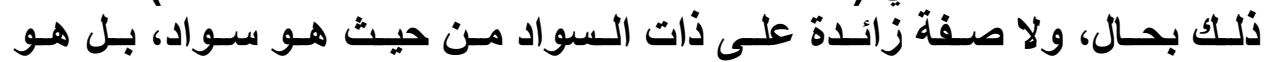
داخل في الذات والحقيقة) (ب)

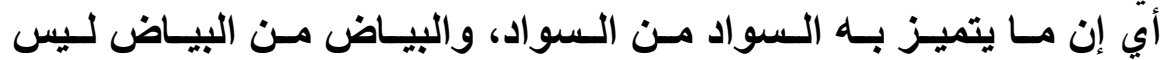

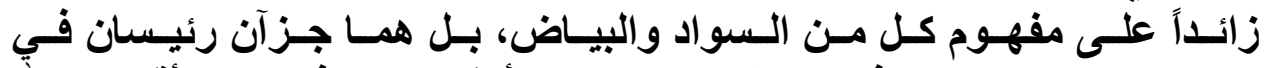

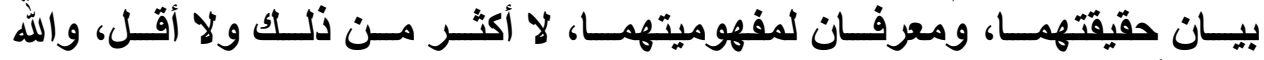

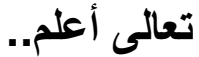

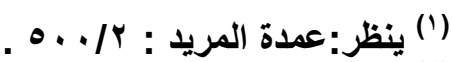

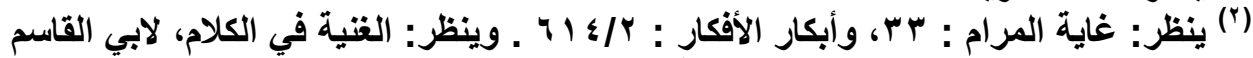

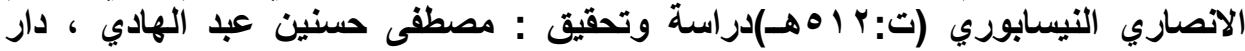

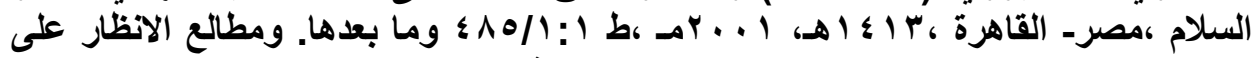

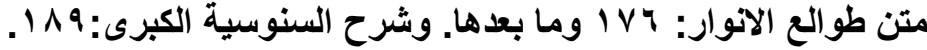




\section{المبحث الثاني \\ النافون للأحوال ووجه اعتراضهم \\ المطلب الأول}

\section{رأي المعتنزلة ووجه 1 اعتراضهم}

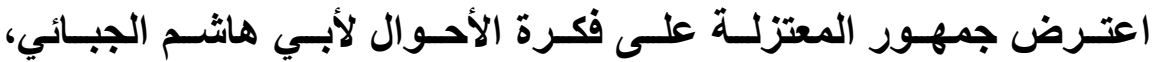

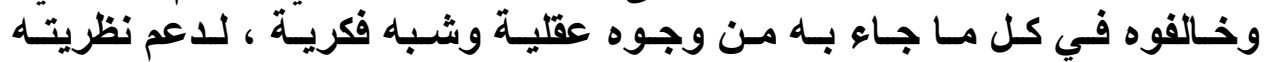

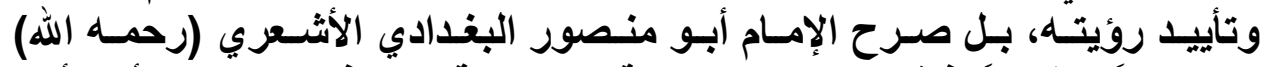

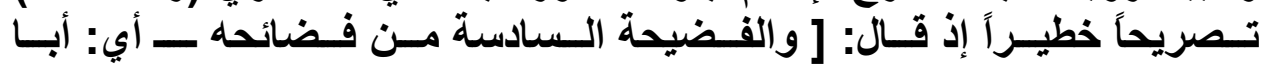

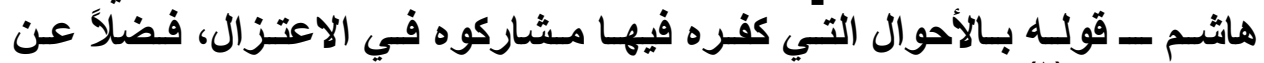

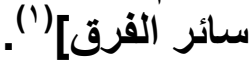

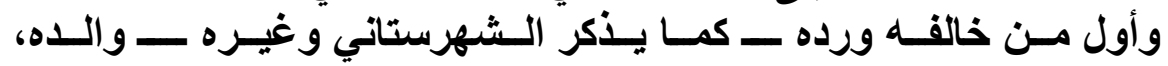

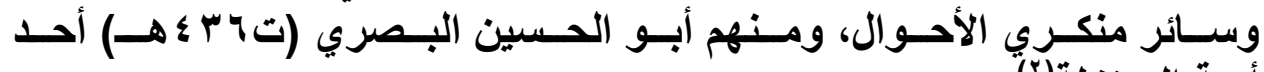

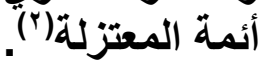

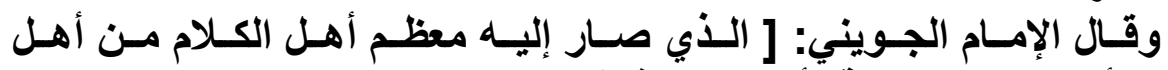

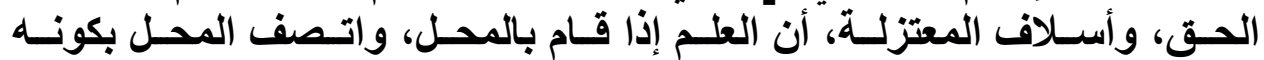

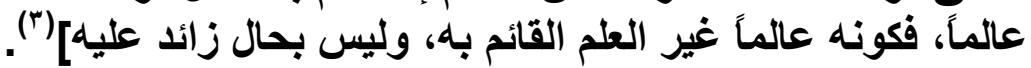

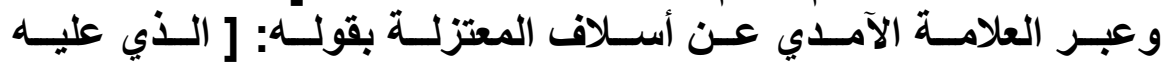

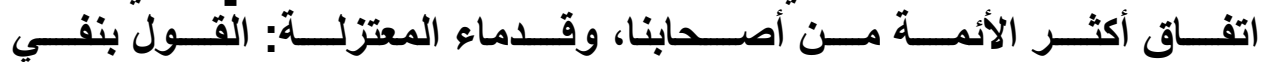

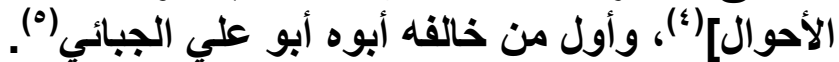

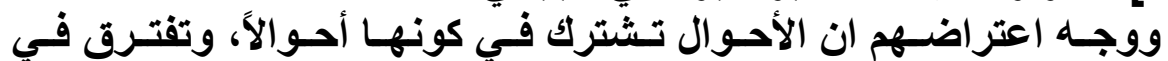

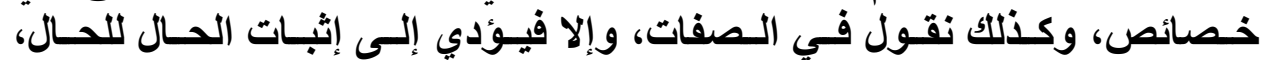

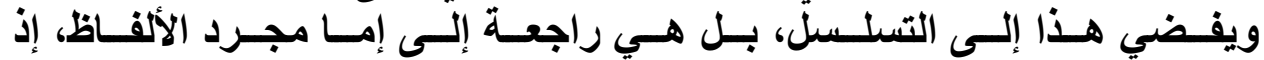

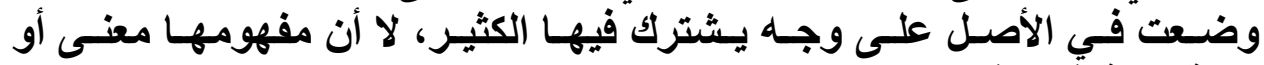
صفة ثابتة في الأت الات.

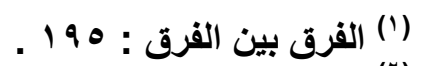

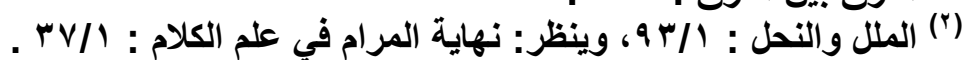

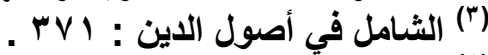

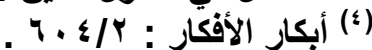

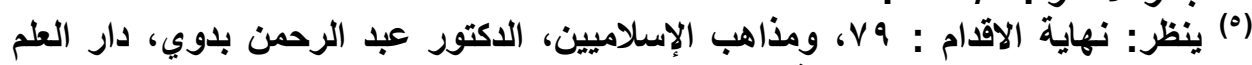

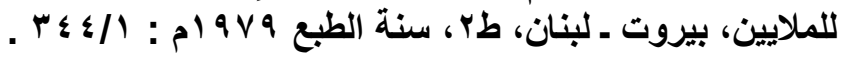




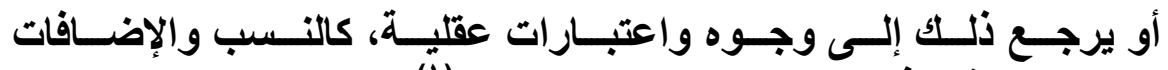

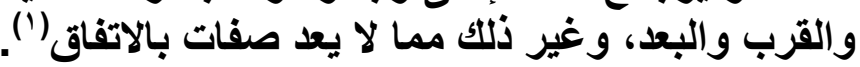

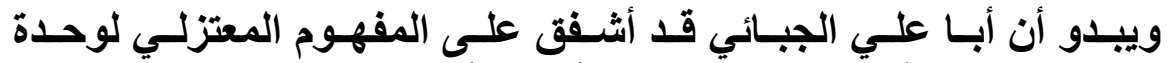

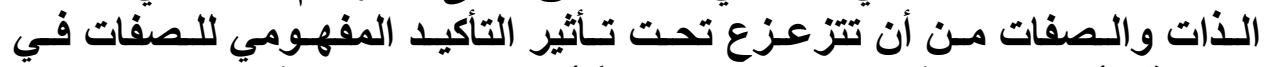

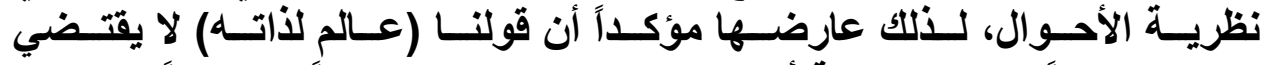

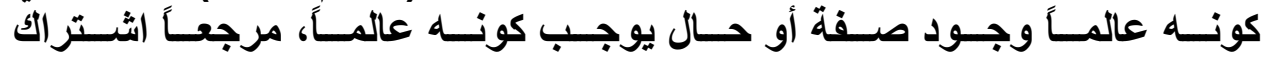

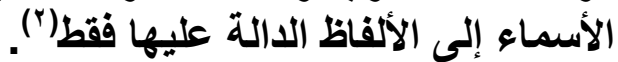

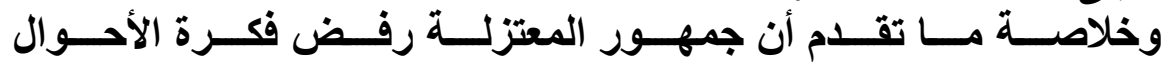

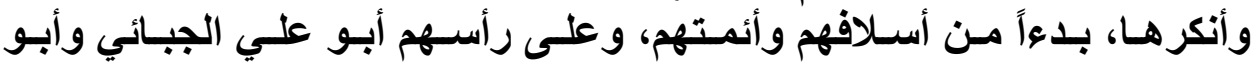

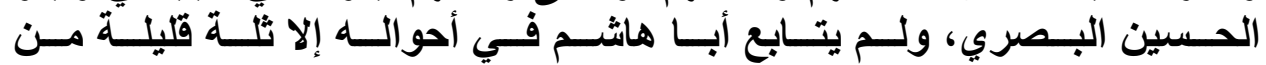

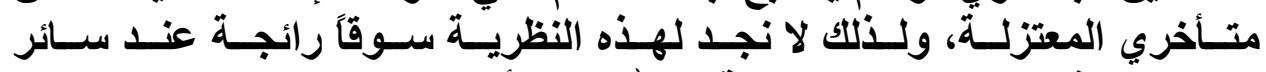

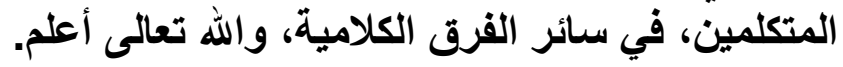
المطلب الثانبي ولهي

\section{رأي الامامية ووجه اعتراضهم}

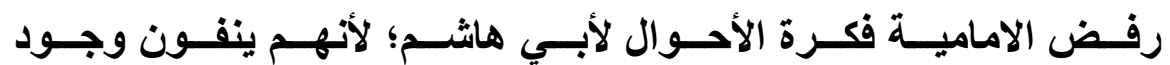

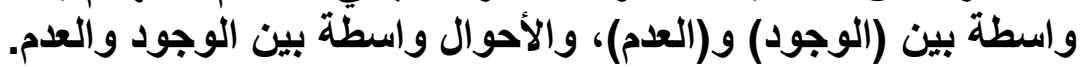

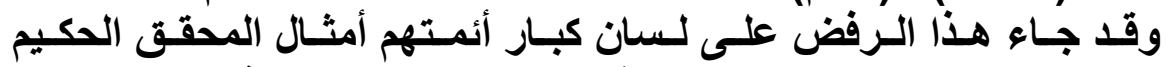

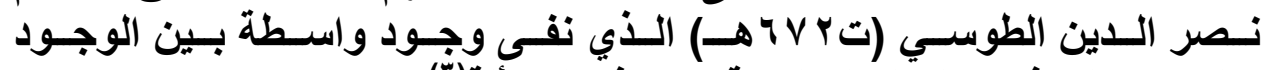

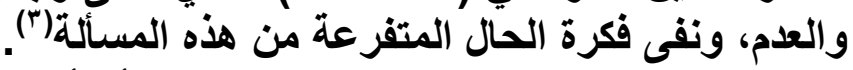

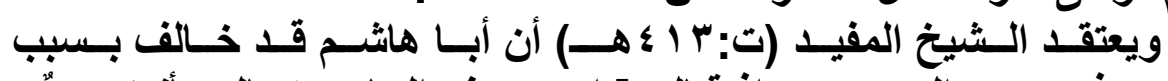

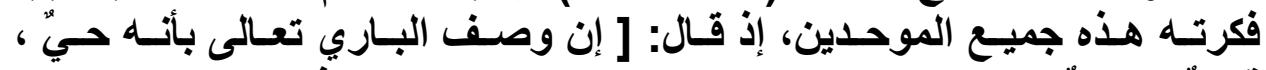

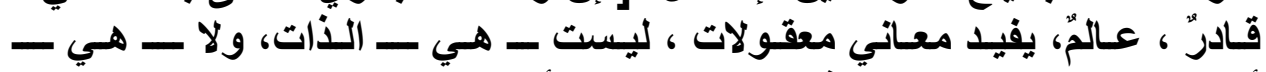

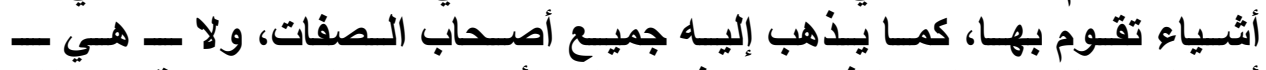

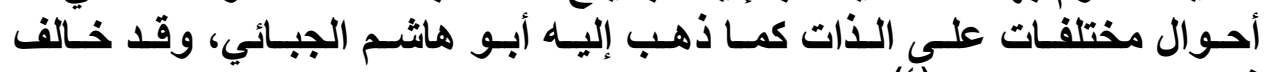
فيه جميع الموحدين]

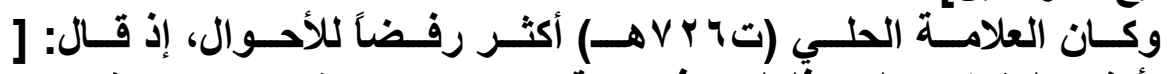

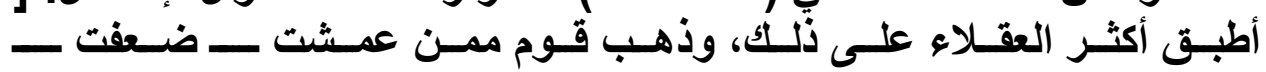

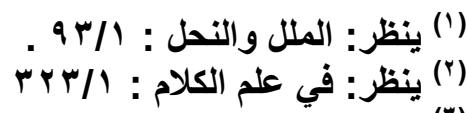

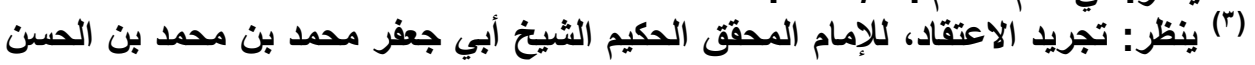

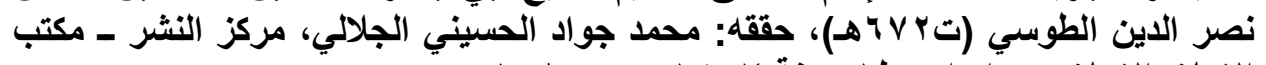

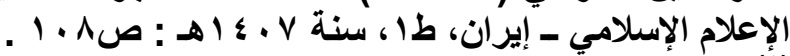

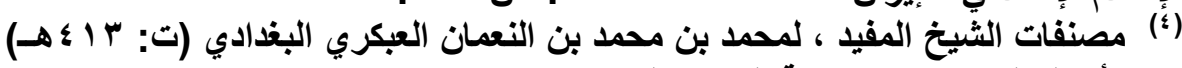

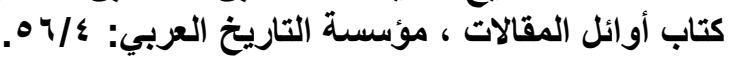




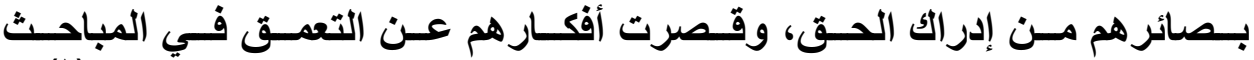

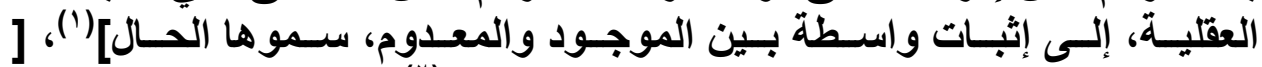

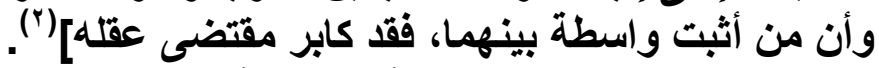

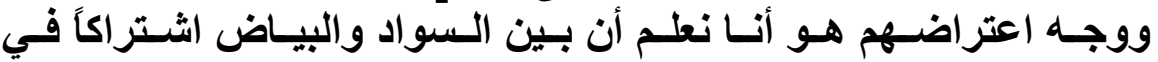

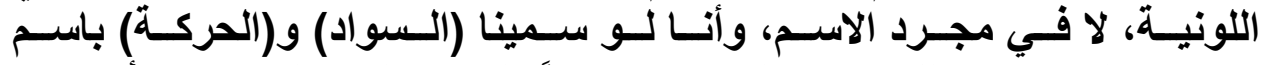

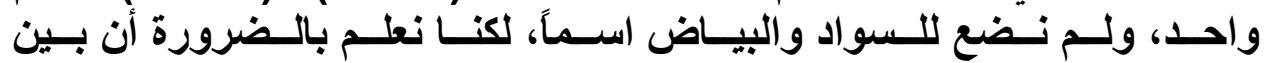

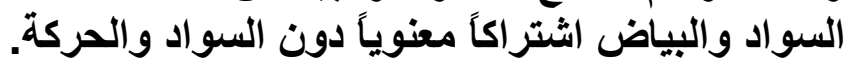

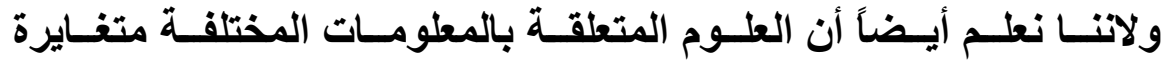

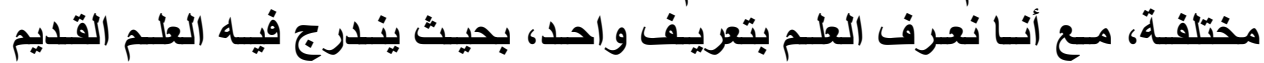

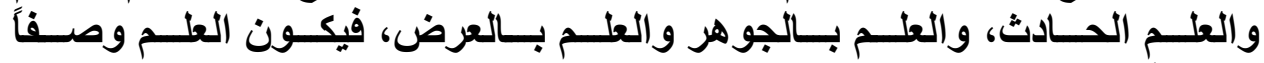
مشتركاً.

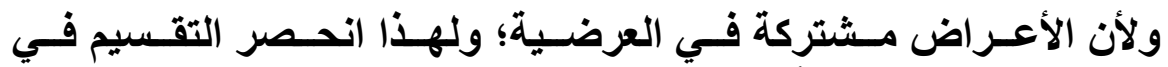

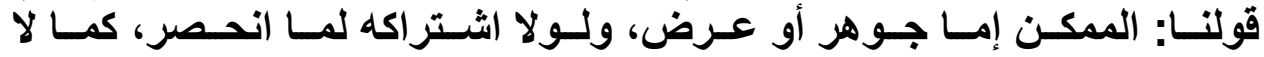

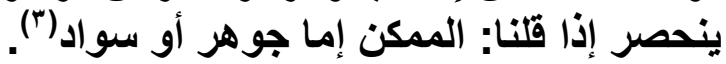

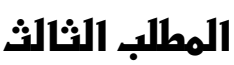

\section{رأي الأنا عرة ووجه اعتراضهم}

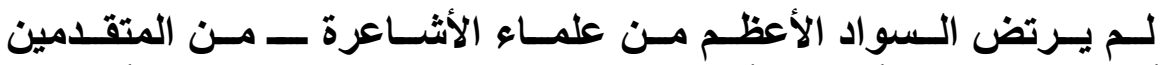

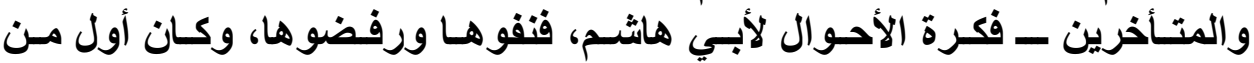

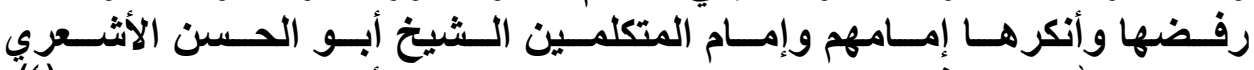

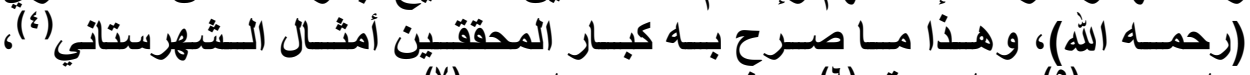

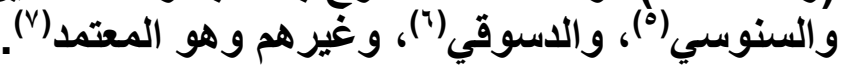

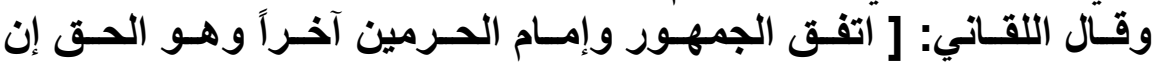

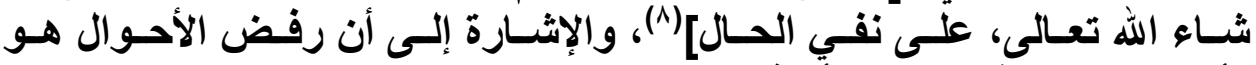

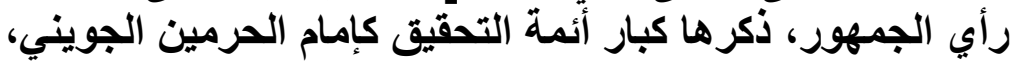

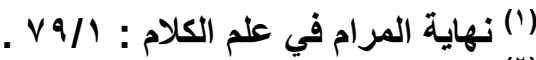

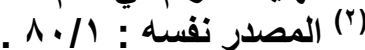

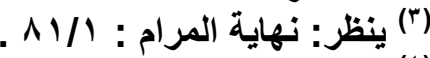

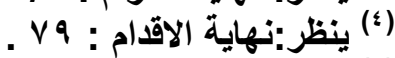

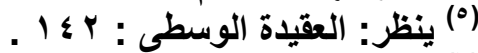

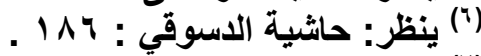

$$
\begin{aligned}
& \text { ينظر: عون المريد : (V) }
\end{aligned}
$$

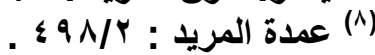




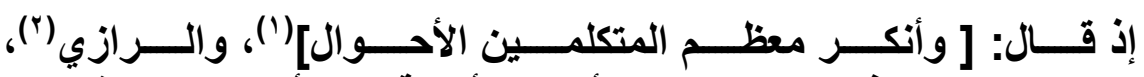

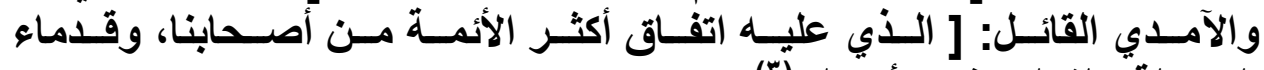

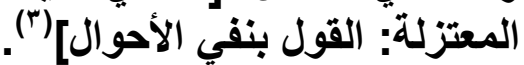

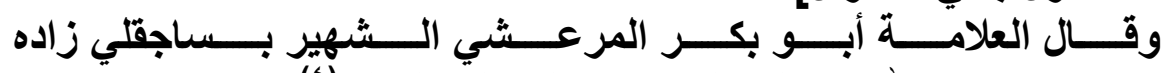

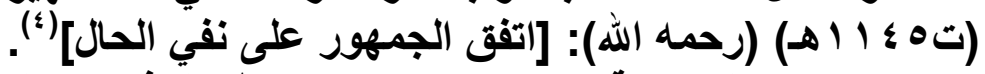

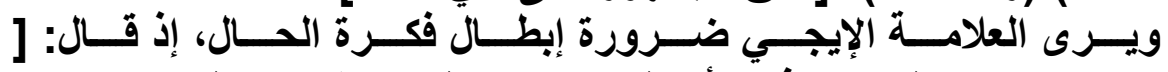

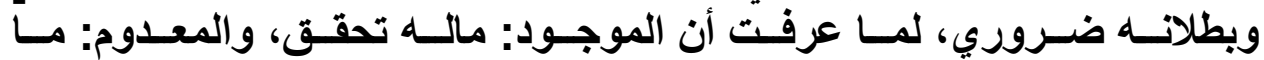

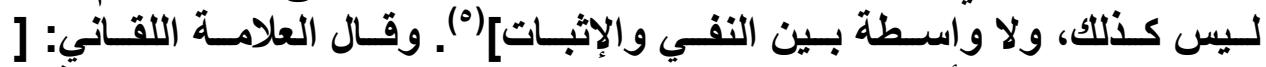

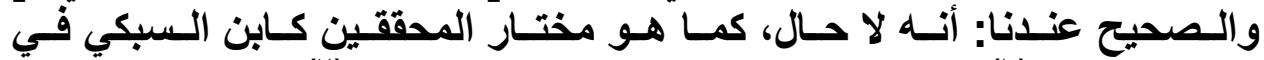

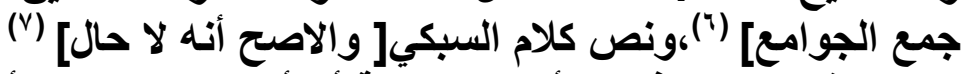

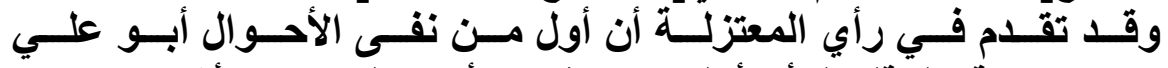

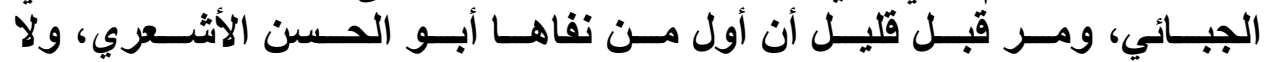

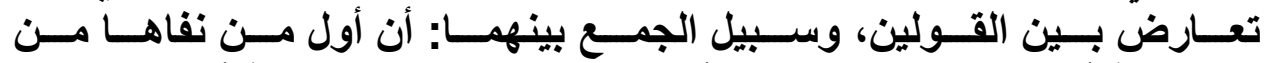

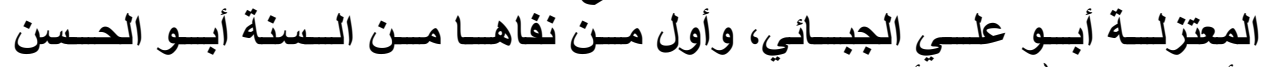

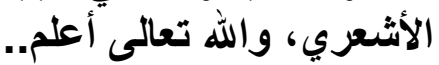
ولثلأشاعرة وجوه اعتر اضية كثيرة أشهرها ثلاثلة:

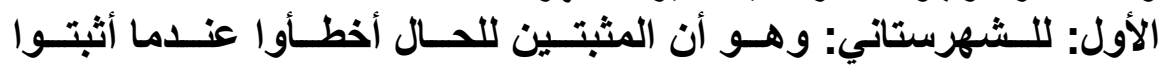

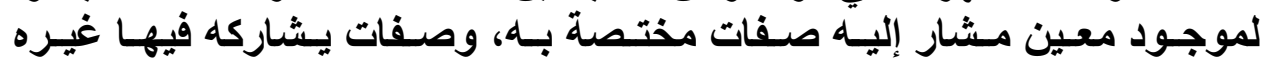

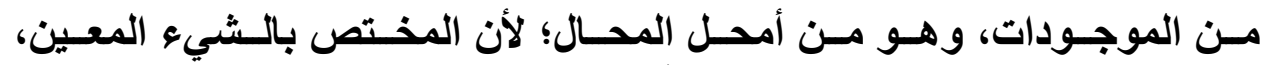
والذي يشاركه فيه غيره، واحد وبـ بالنسبة إلى ذلتك المعين.

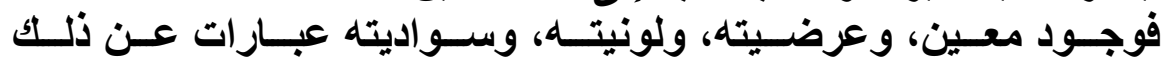

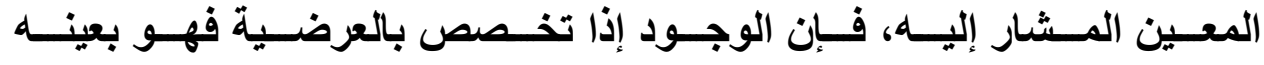
عرض.

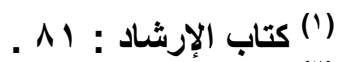

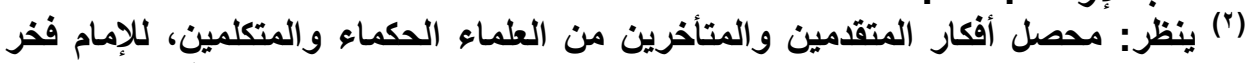

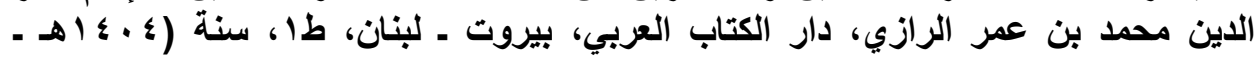

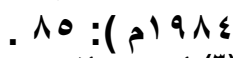

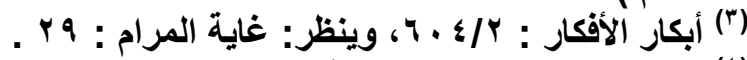

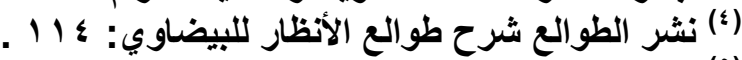

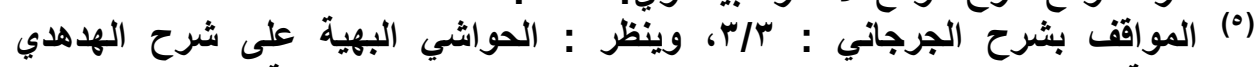

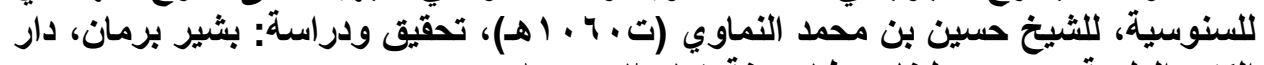

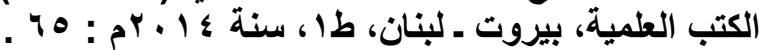

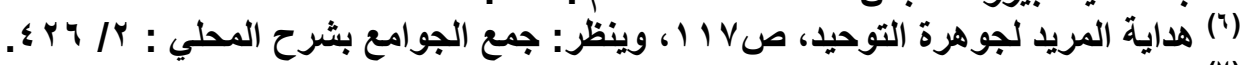

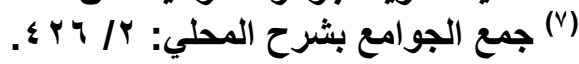




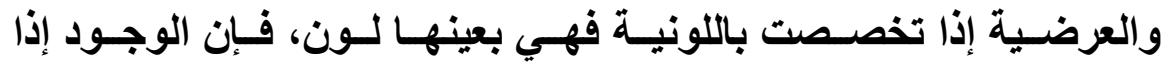

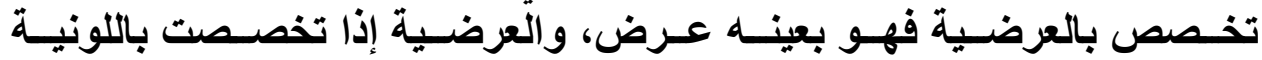
فهي بعينها لون.

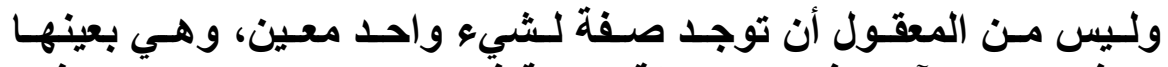

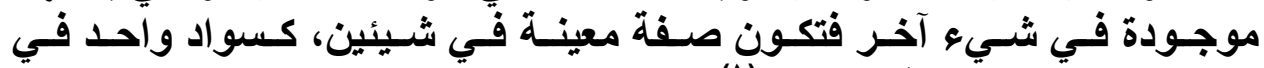

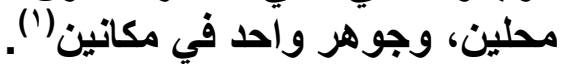

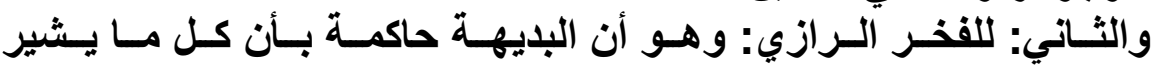

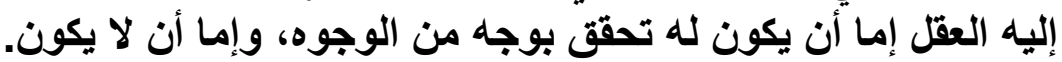

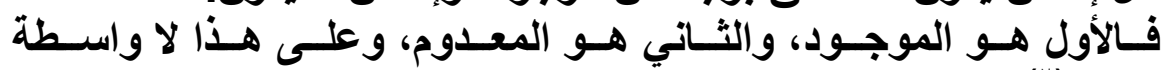

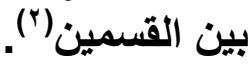

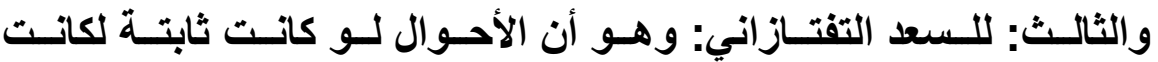

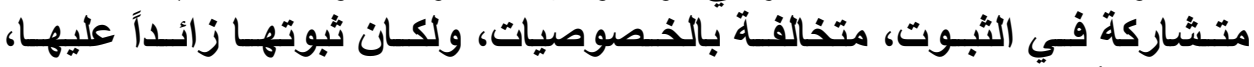

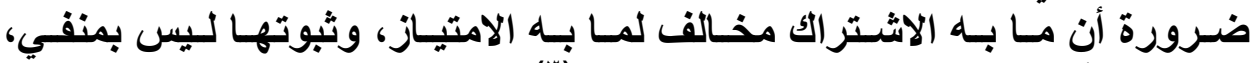

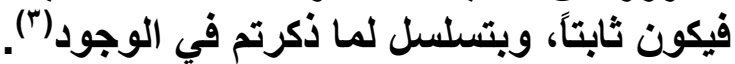

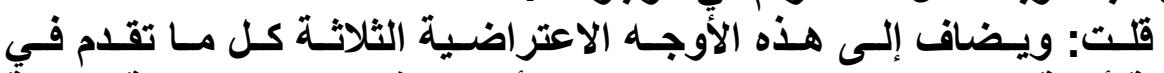

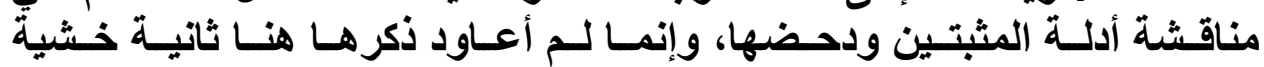

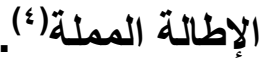




\section{المبمث الثالث}

\section{أصماب القولين ( المثزددون )}

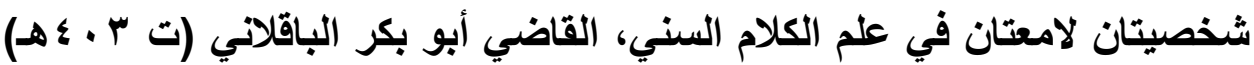

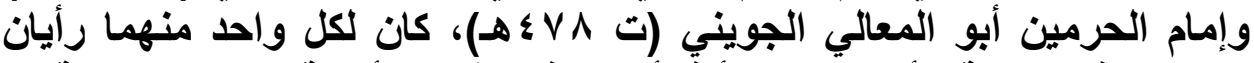

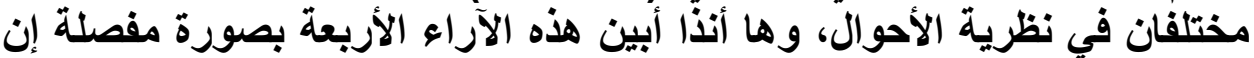

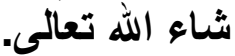

\section{المطلب الاول \\ القاضي الباقلاني}

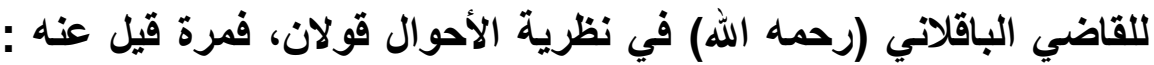

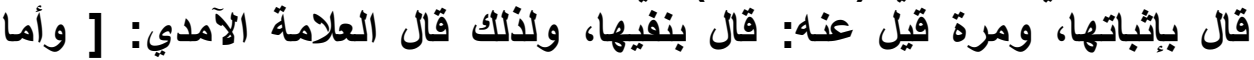

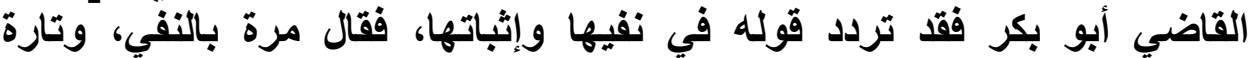

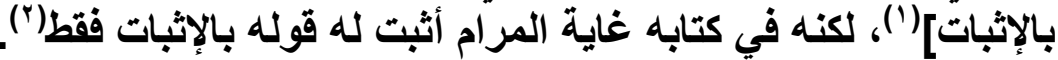

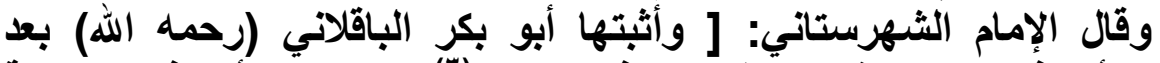

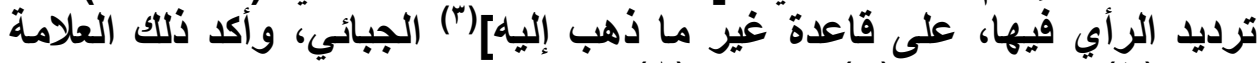

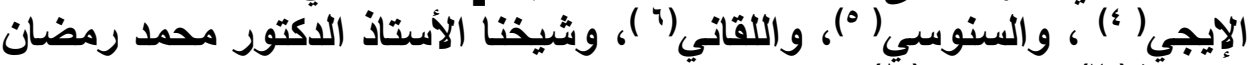

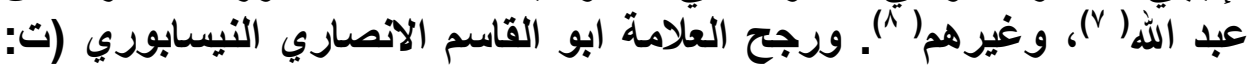

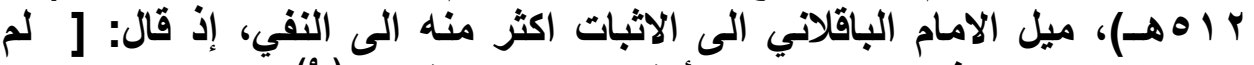

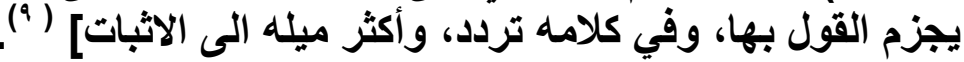

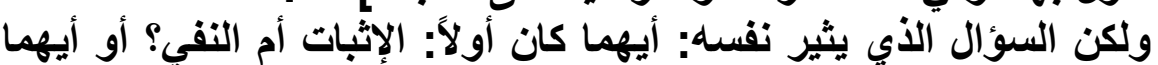
كان آخراً: الإثبات أم النفي؟ الني

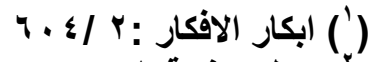

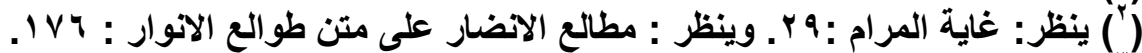

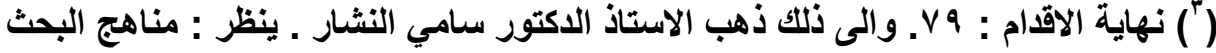

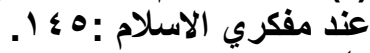

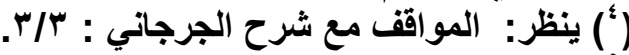

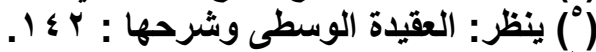

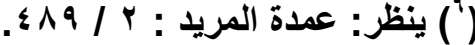

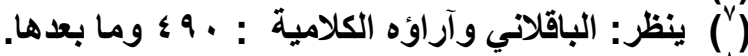

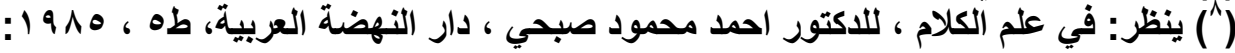
1. r I /

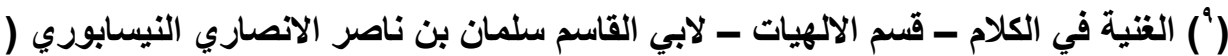

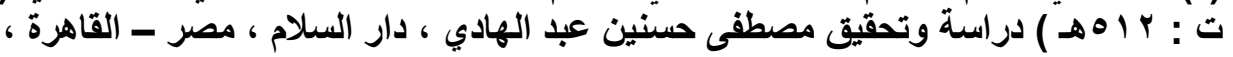

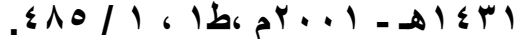


ثم إذا كان مصدر النفي هو مؤلفاته فما مصدر الإثبات؟

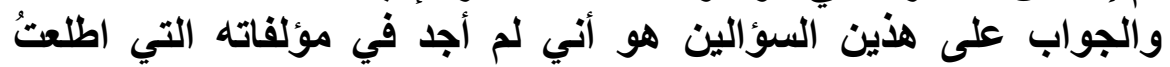

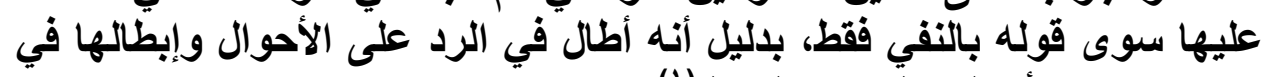

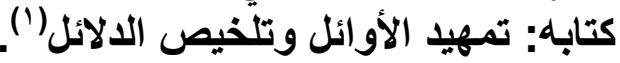

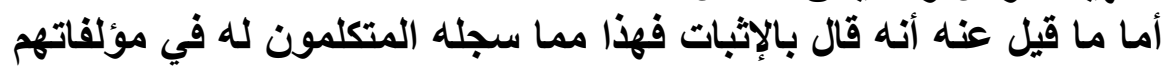

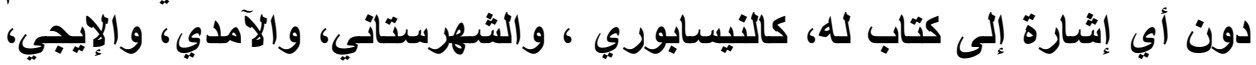

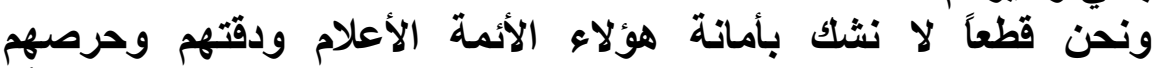

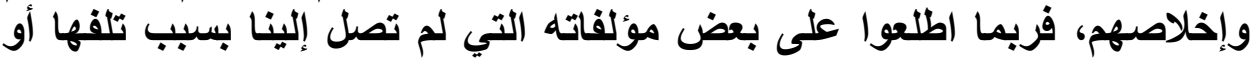
ضياعها، فوجدوا فيها قوله الثاني وهو الإثبات.

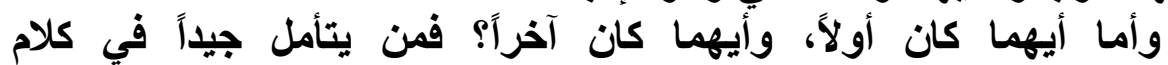

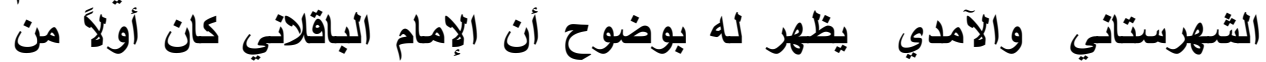

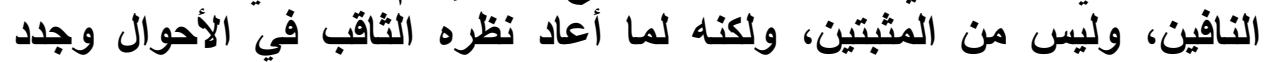

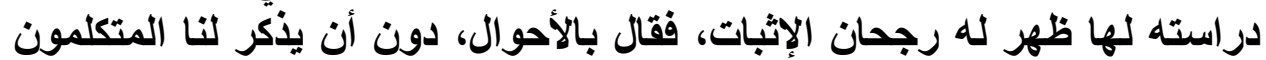
أدلته التي اعتمدها في الاثبات.

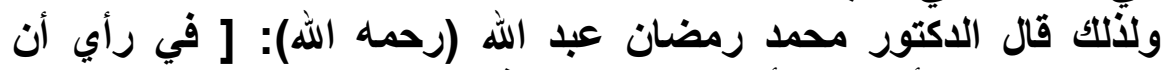

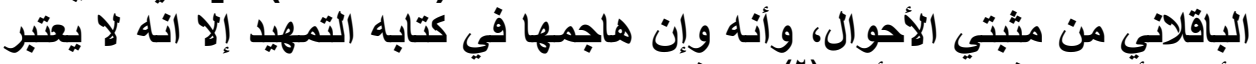

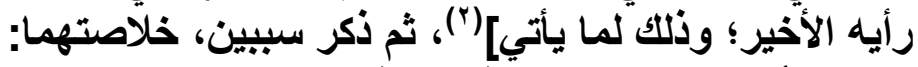

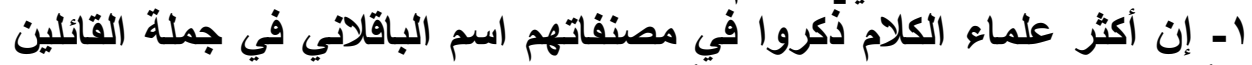

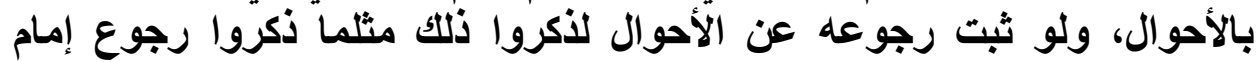
الحرمين عنها. ب- لا يعد كتاب التمهيد الذي هاجم فيه الباقلاني فكرة الأحوال آخر مؤلفاته، بل فيل

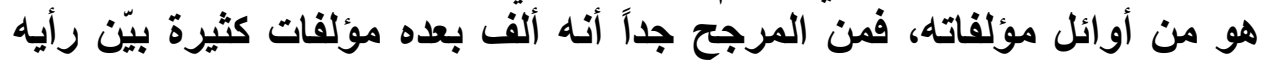

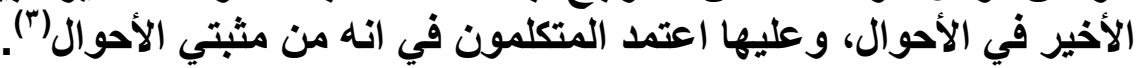

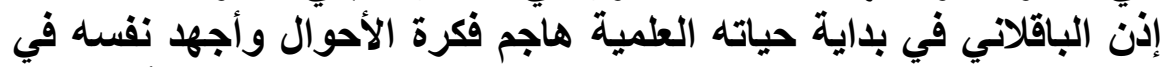

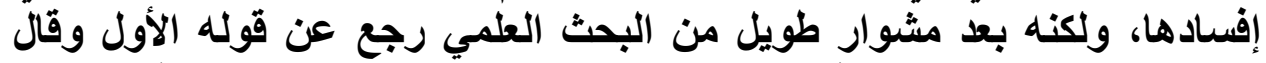

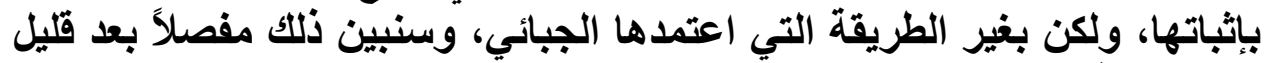
إن إن شاء الله.

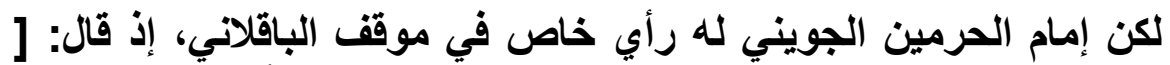

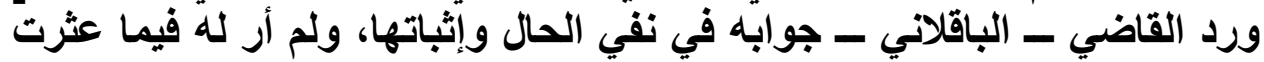

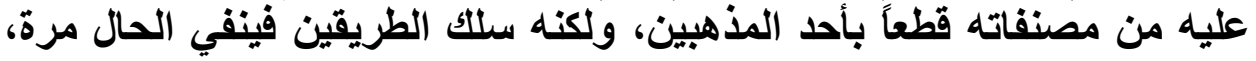


ويثتبها أخرى، ويجري قواعد الأصول على الطريقين، ليستبين للناظر استمرار

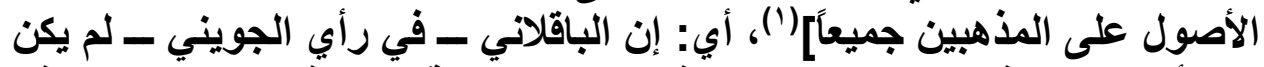

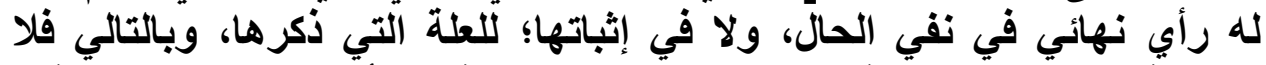

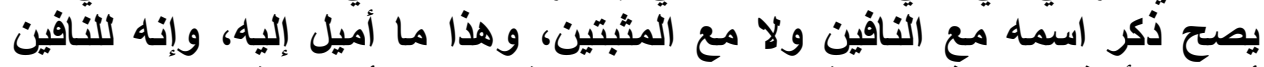
أقرب للأدلة القاطعة على ذلك، وهو إسهابه في في نفي الأحوال في كتاب: تمهيد

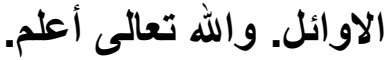

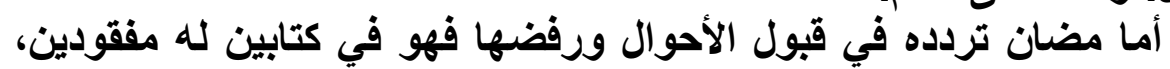

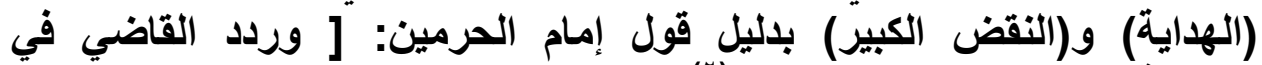

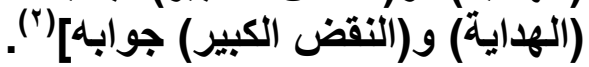
المطلب الثاني: إمام الحرمين الجويني.

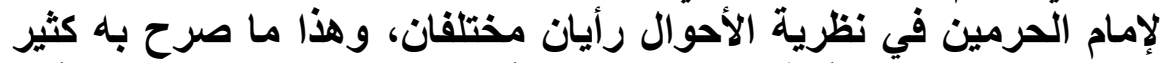

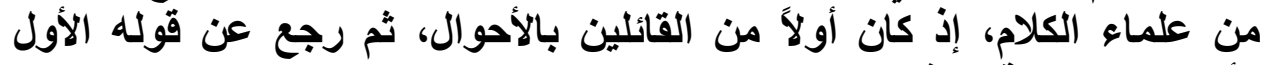

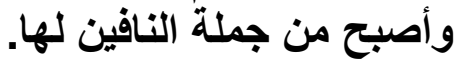

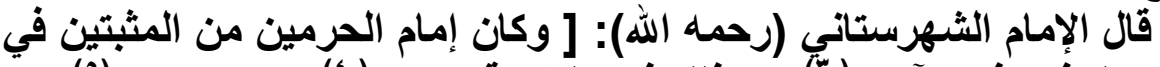

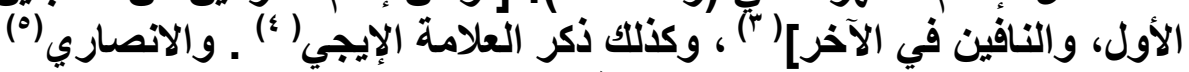

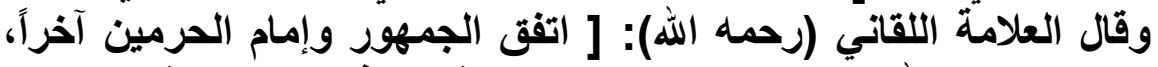

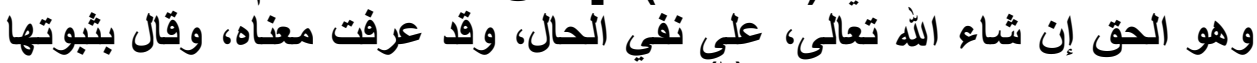

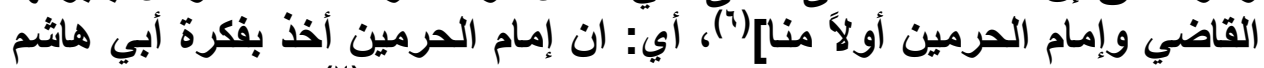

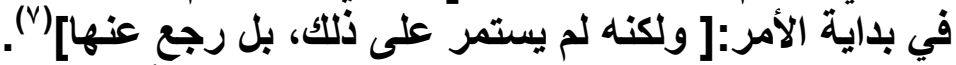

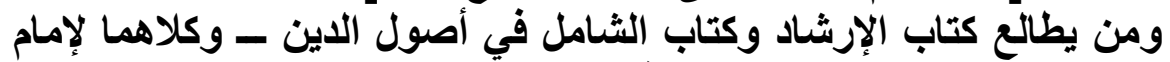

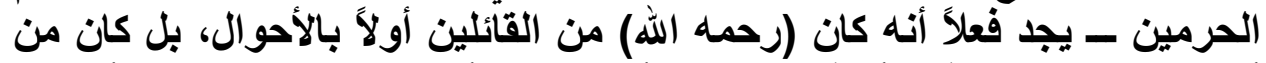

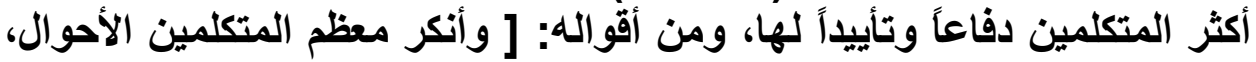

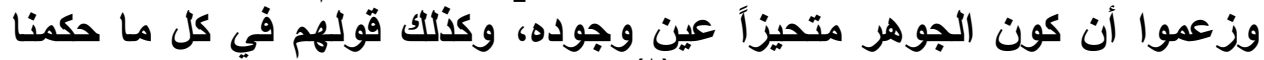

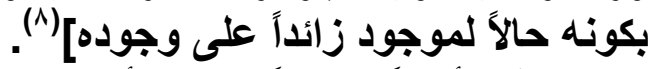

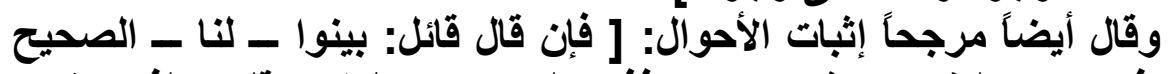

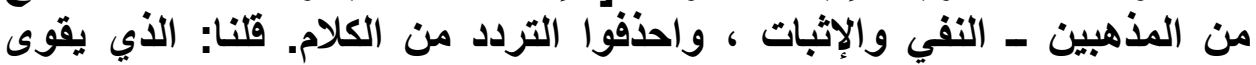

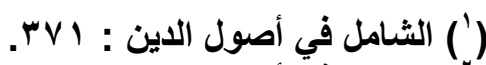

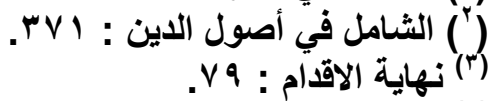

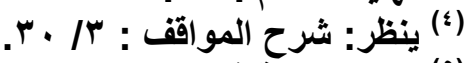

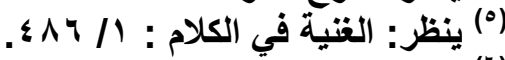

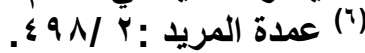

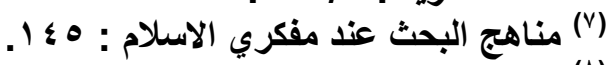

$$
\begin{aligned}
& \text { (^) كتاب الارشاد : 1) }
\end{aligned}
$$




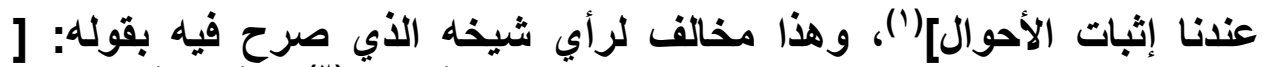

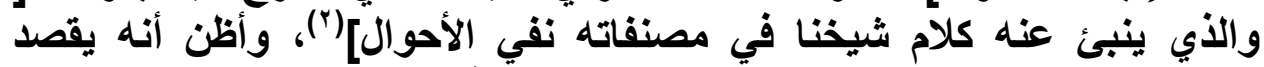

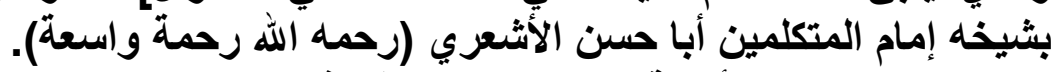

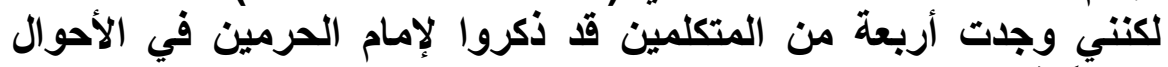

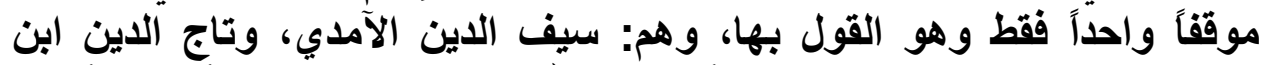

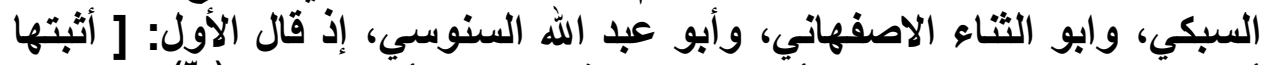

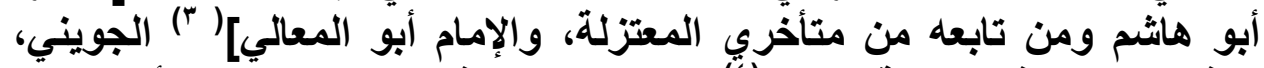

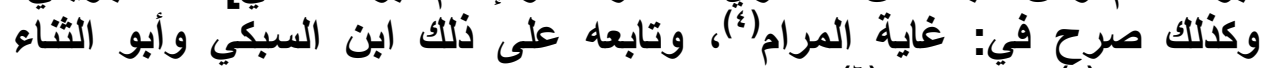
الاصفهاني (0) و السنوسي: غاية (4). والأدق في رأي مـا ذكره الانصاري والثهرستاني والإيجي و اللقاني، بلاليل

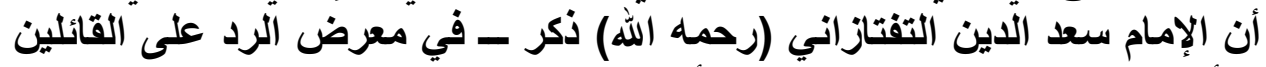

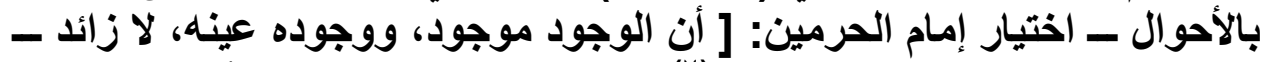

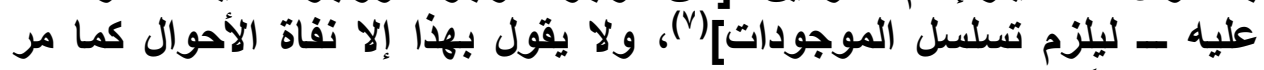

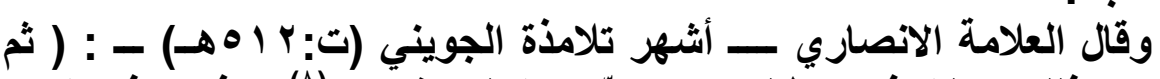

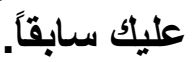

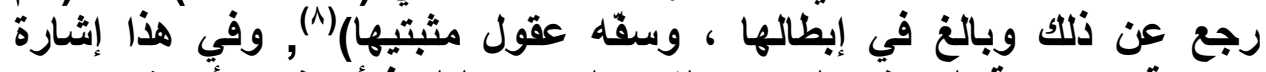
واضحة وصريحة الى نفي الجويني للاحوال، لان التلميذ أعرف برأي شيخه من قلت: ومما يقطع برجوع الجويني عن الاحوال هو نفيه الصريح لها في والئ

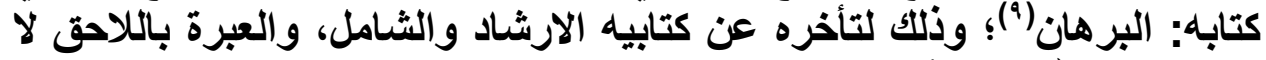

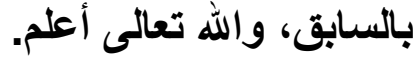

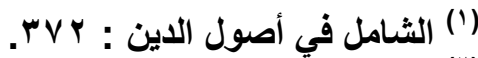

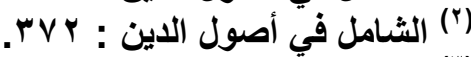

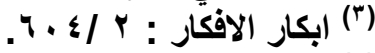

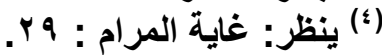

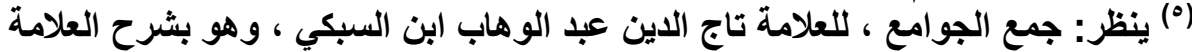

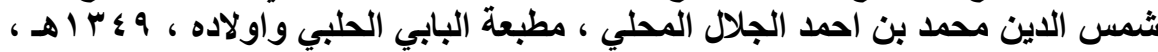

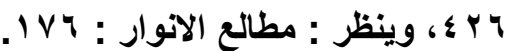

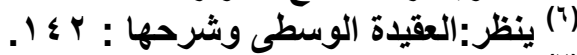
(V)

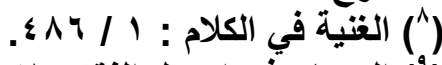

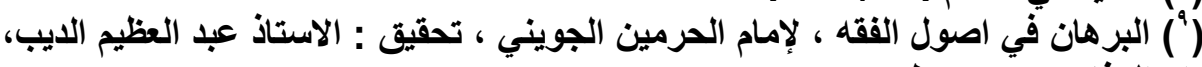

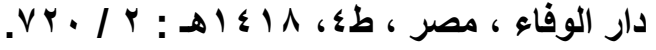


ونص كلام الجويني: ( من أثبت الاحوال وزعم أن كون النان العالم عالماً

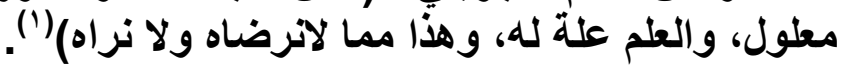
وبعد دراسة موقف الإمامين الجليلين - الباقلاني والجانئ والجويني - من فن فكرة

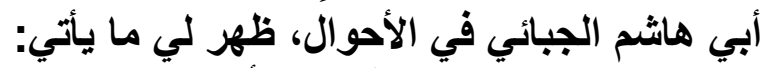

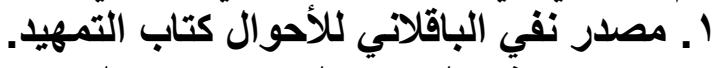

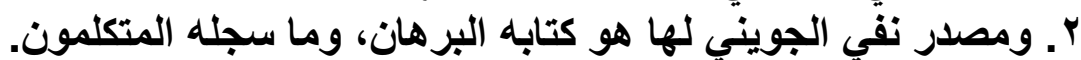

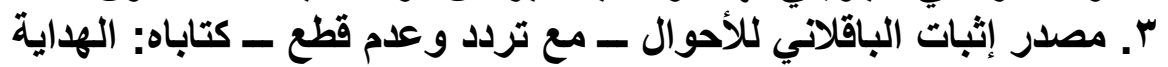

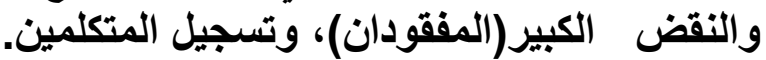

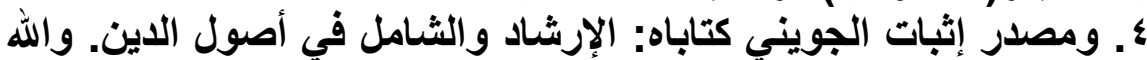




\section{نتائج الار اسة}

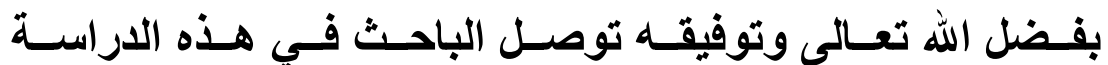
إلى نتائج علمية مهرة هي:

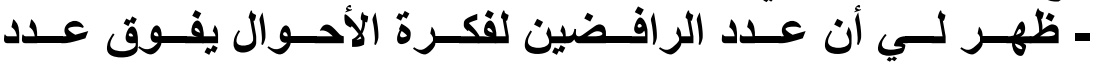

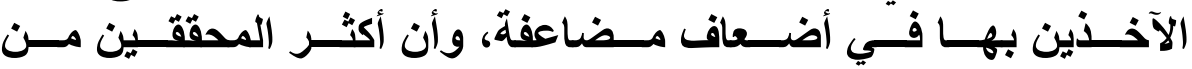

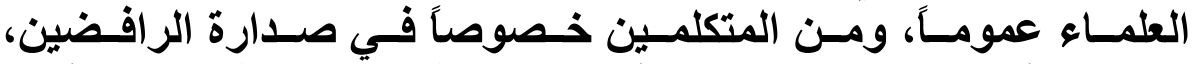

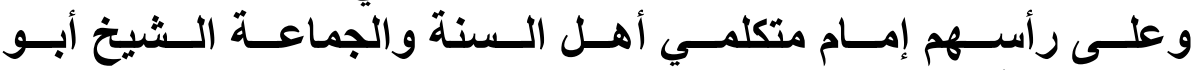

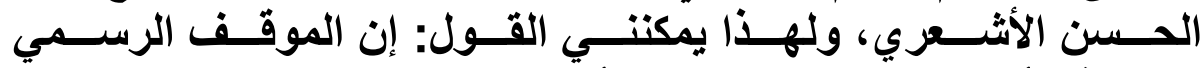

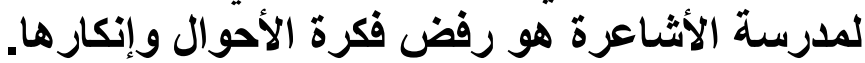

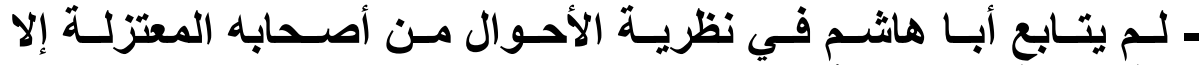

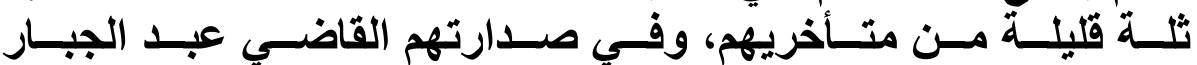

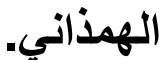

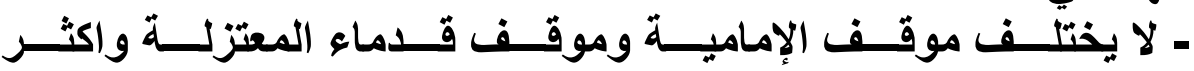

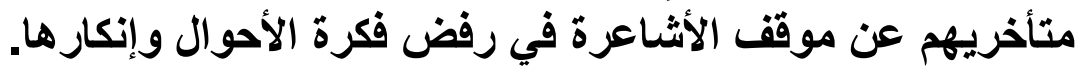

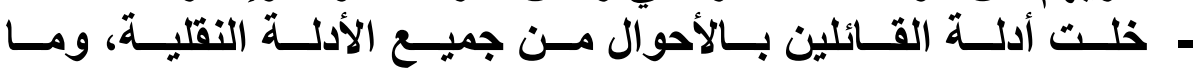

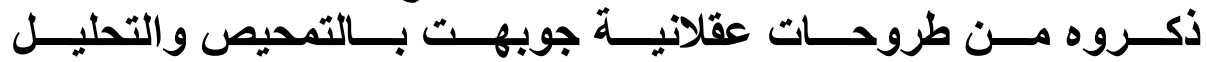

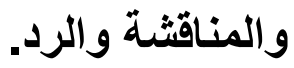

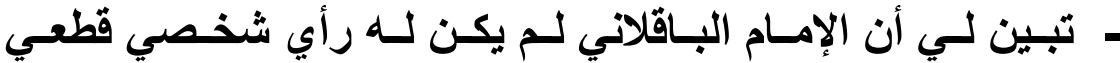

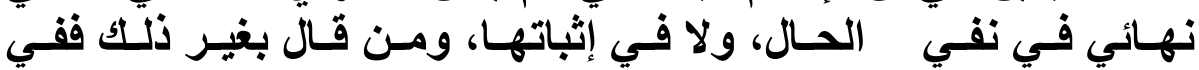
قوله نظر ومناقشة. ـ مصدر نفي الباقلاني للأحوال هو: كتاب التمهيد.

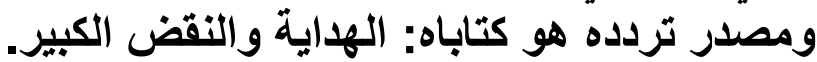

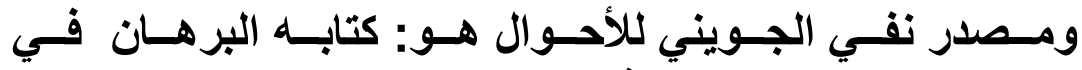

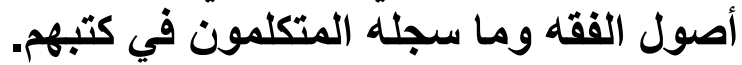
ومسصدر إثباتــه لهـا هـو كتابــاه: الإرشــاد والـشامل فـي أصـول

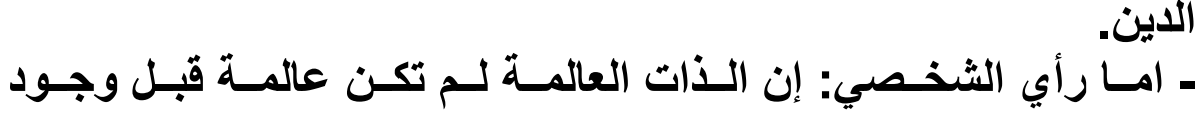

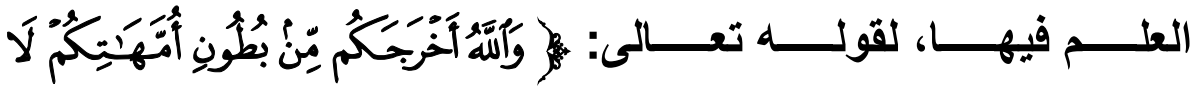

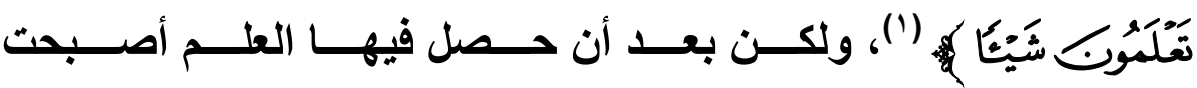




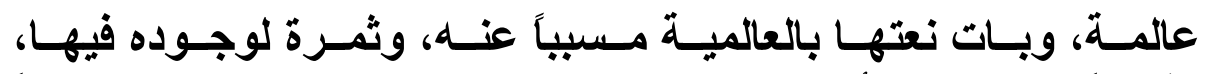

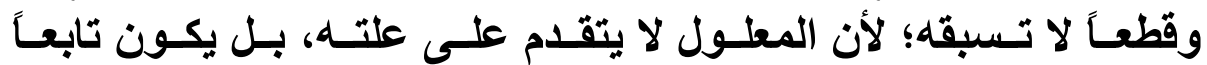

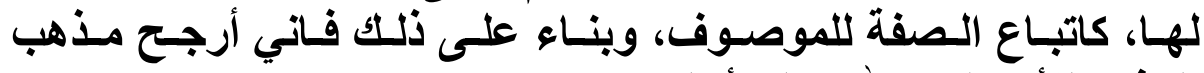

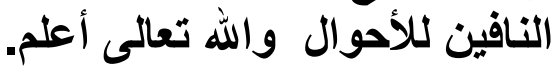
والحمد الله رب العالمين 


\section{المصادر والمراجع}

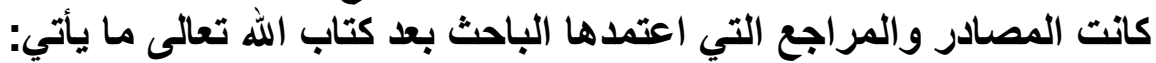

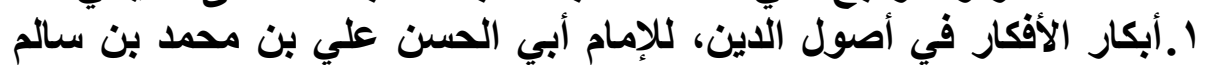

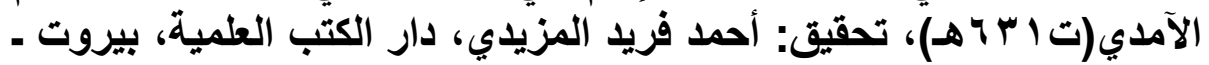

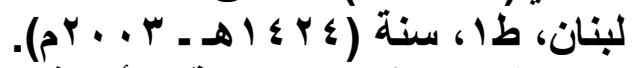

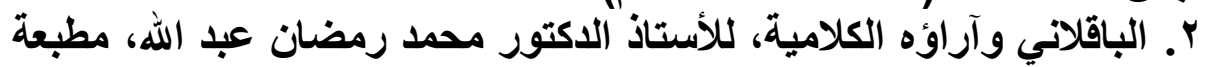

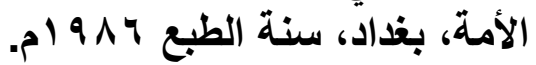

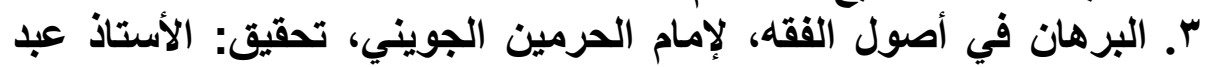

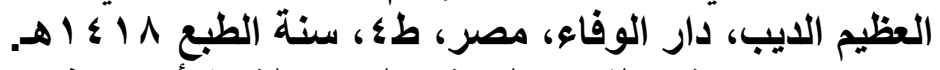

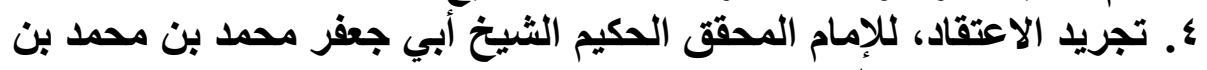

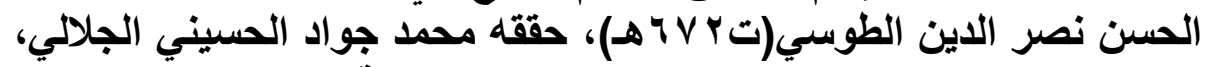

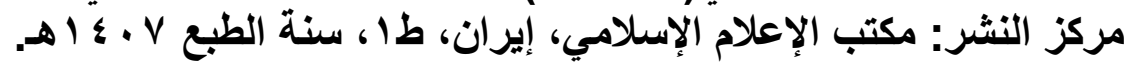

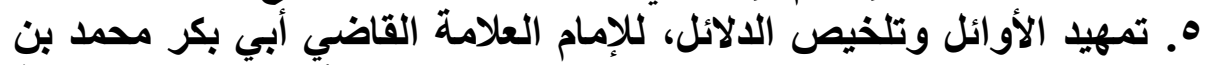

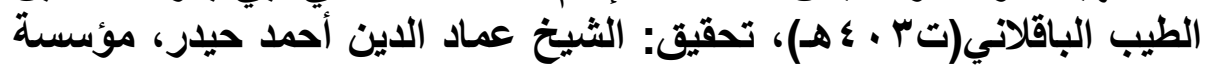

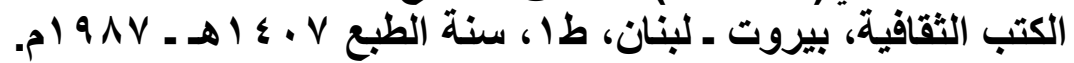

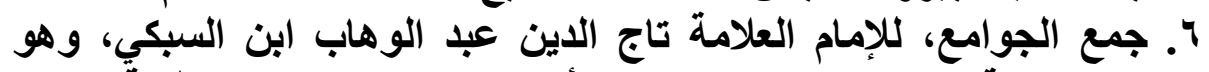

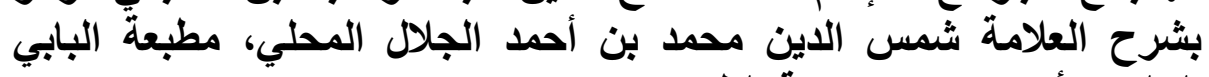

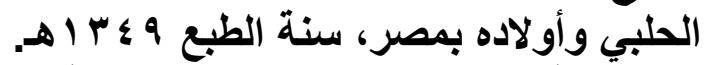

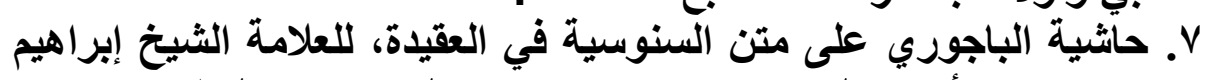

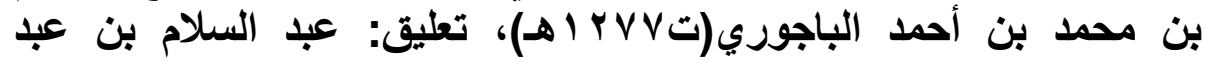

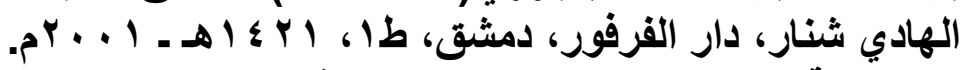

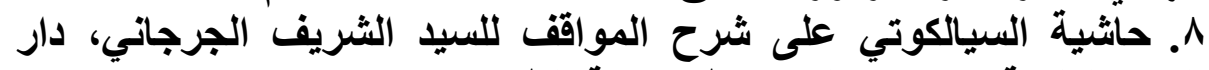

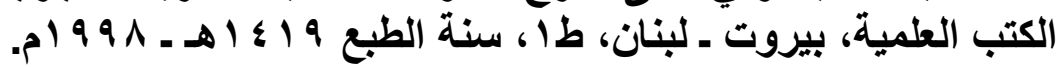

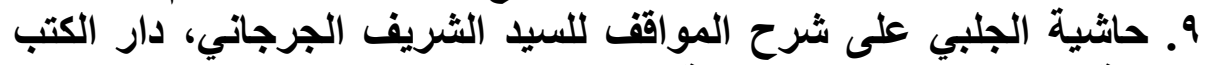

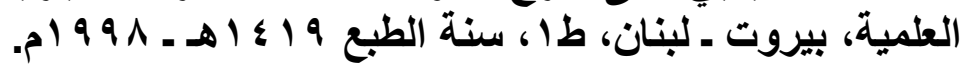

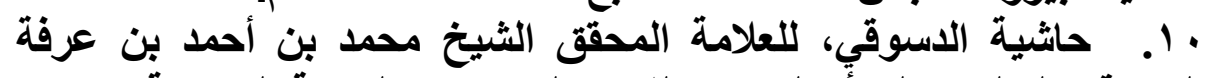

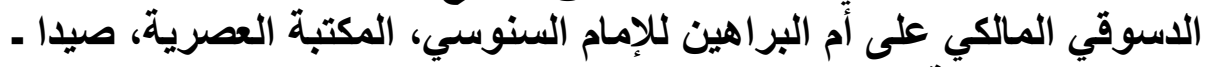

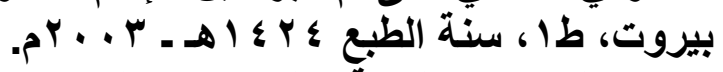

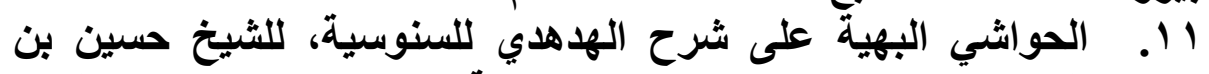

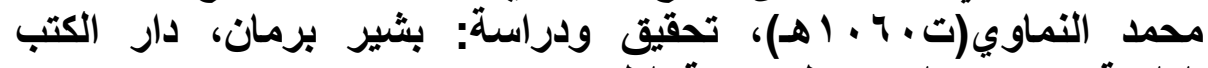

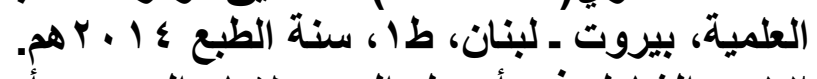

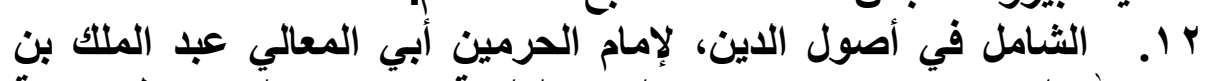

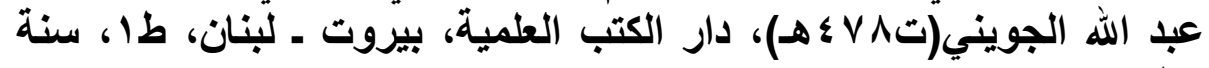

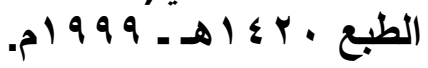




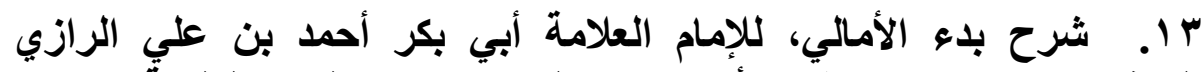

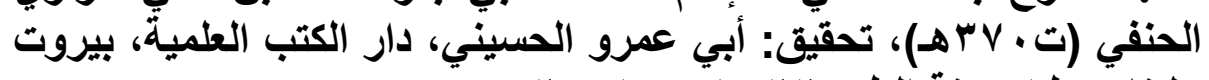

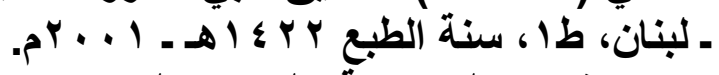

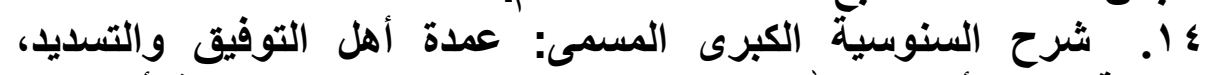

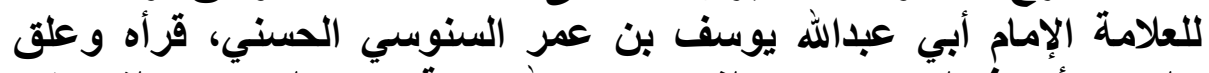

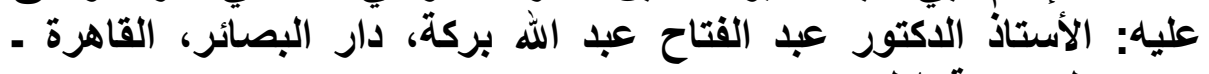

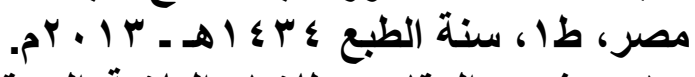

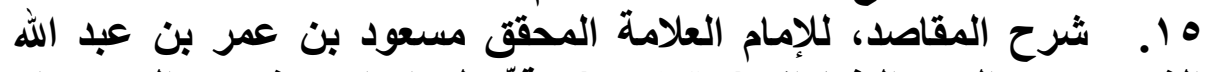

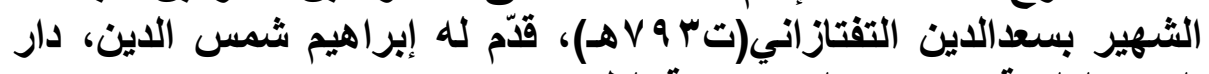

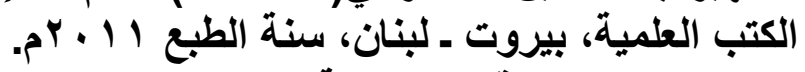

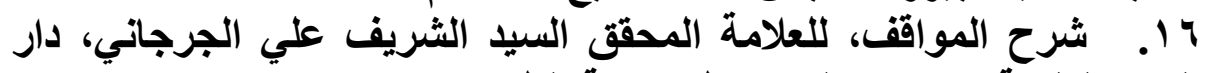

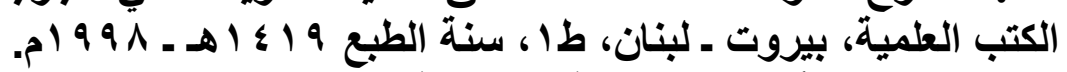
IV

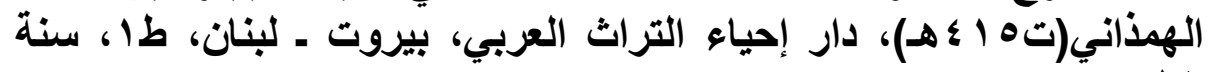

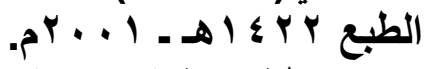

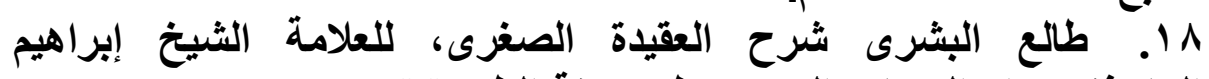

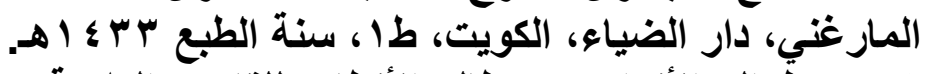

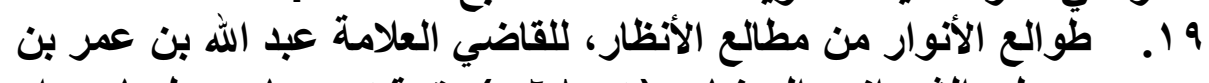

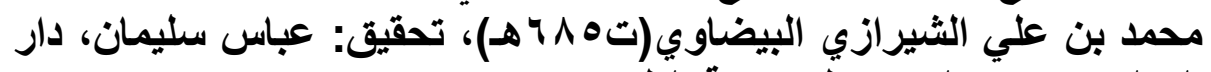

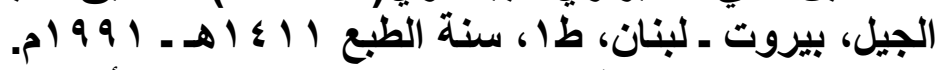

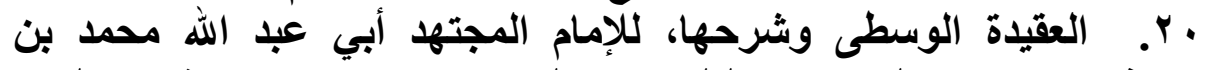

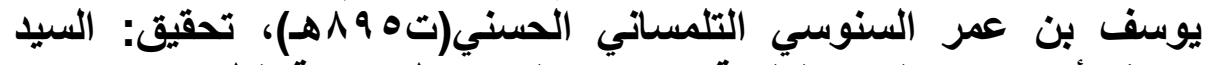

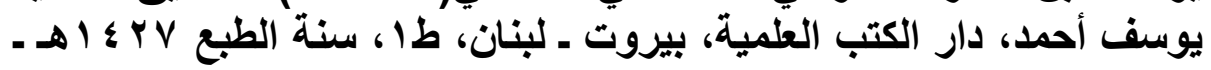

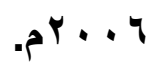

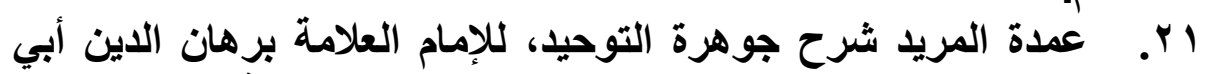

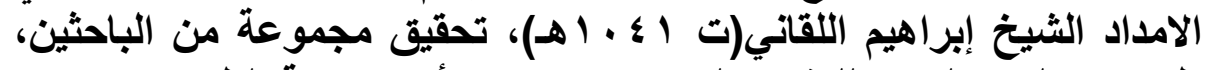

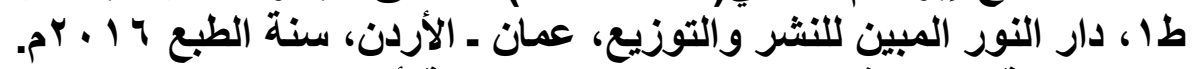

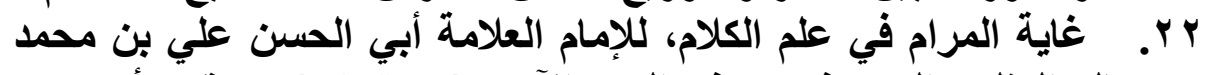

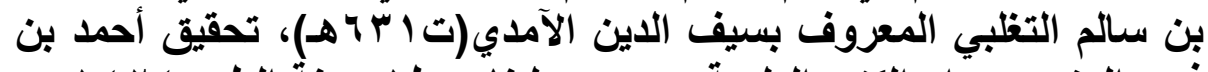

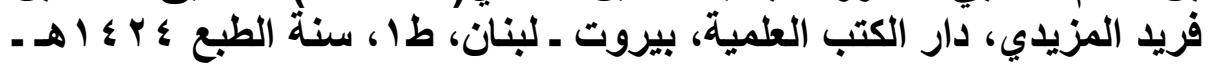

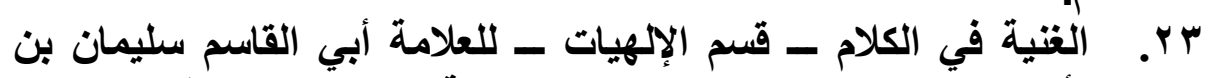

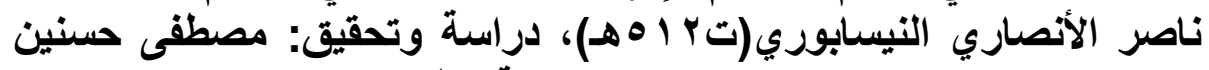

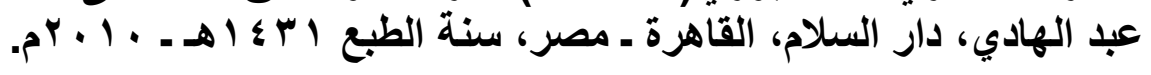


צ Y. الفرق بين الفرق، للإمام أبي منصور عبد القاهر بن طاهر التميمي

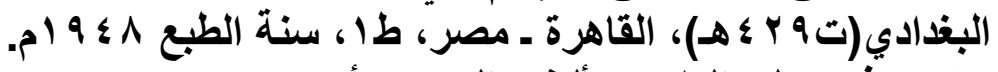

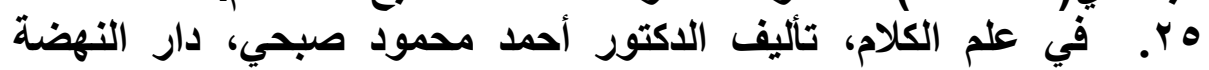

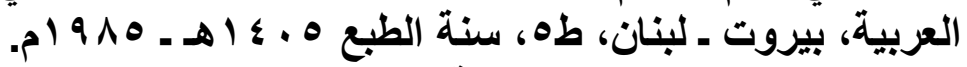

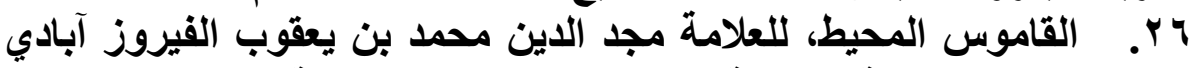

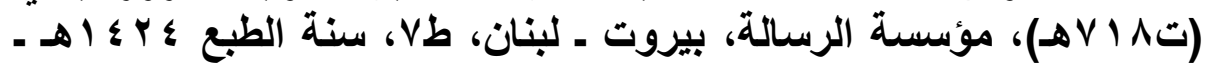

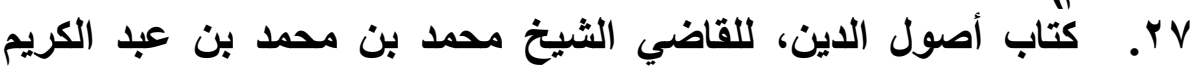

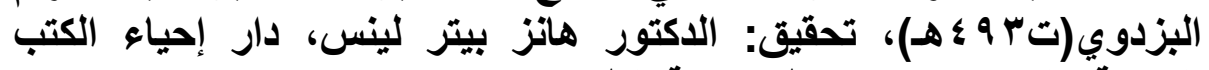

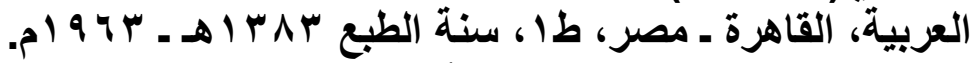

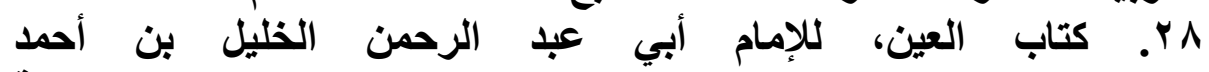

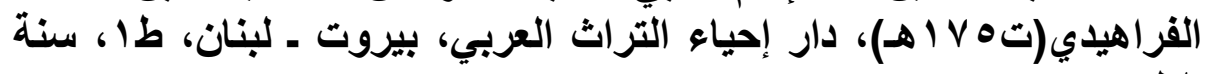

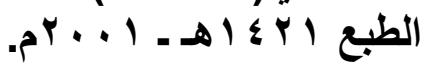

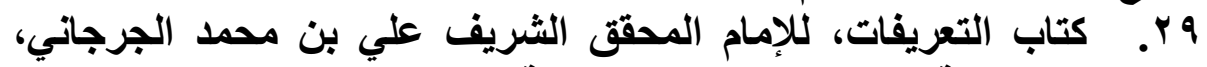

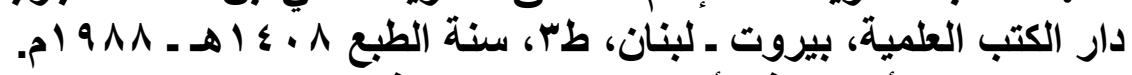

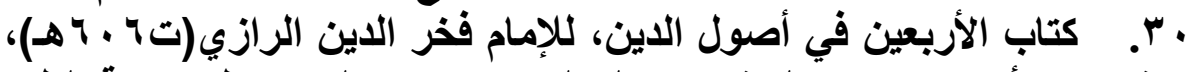

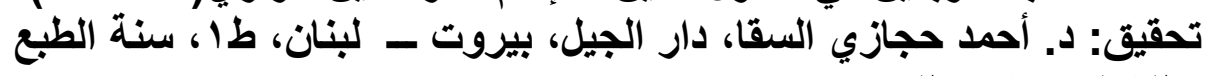

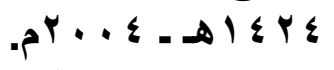
اسّ. ـتاب الإرشاد إلى قواطع الأدلة في أصول الاعتقاد، لإمام الحرمين أبي

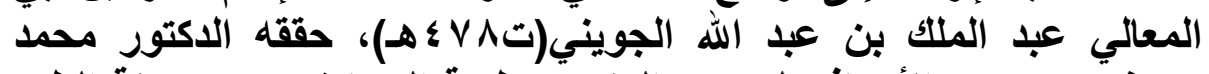

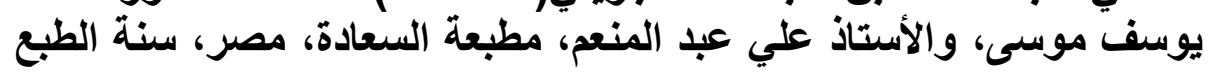

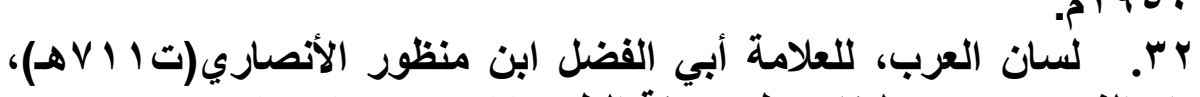

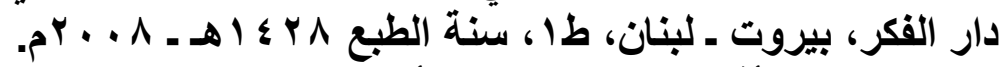

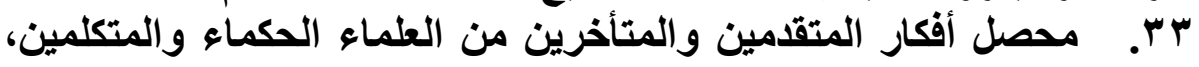

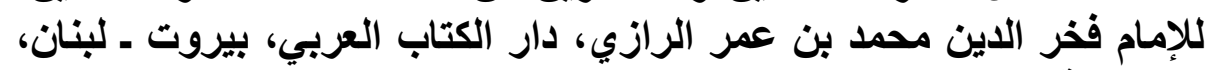

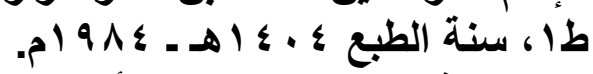

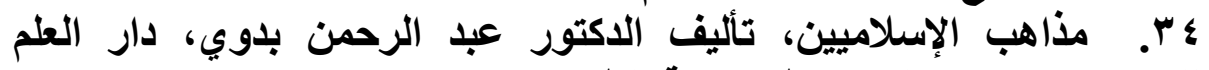

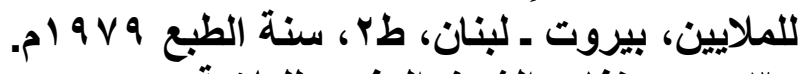

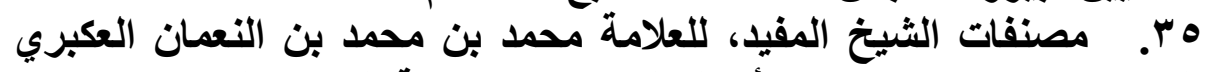

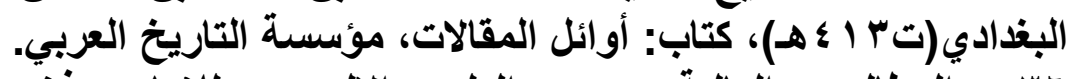

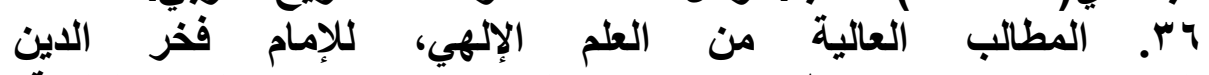

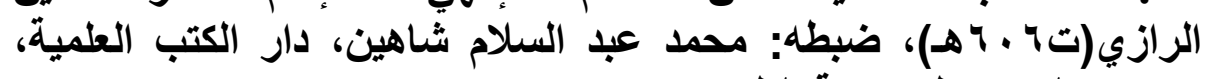

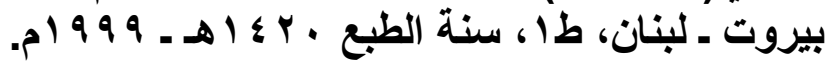


تول. مطالع الأنظار على متن طوالع الأنوار، للإمام العلامة أبي الثناء

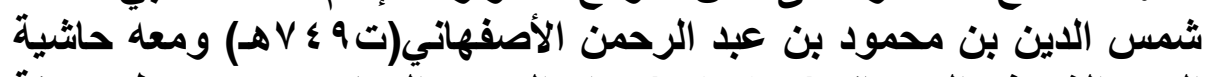

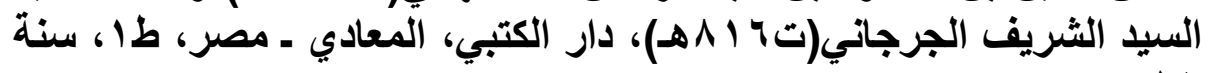

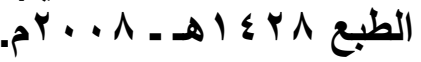

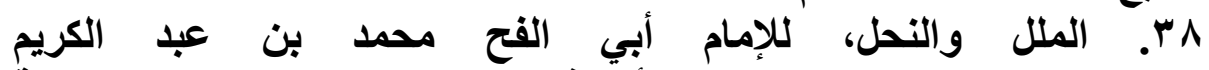

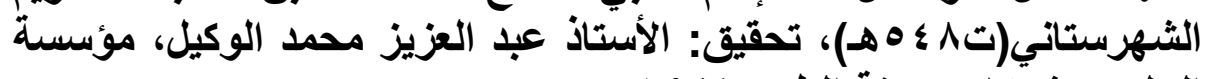

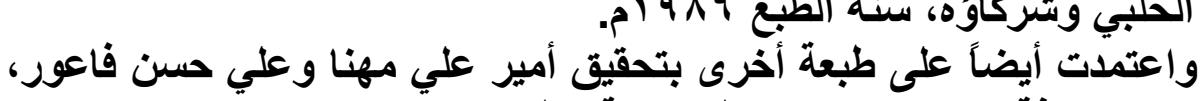

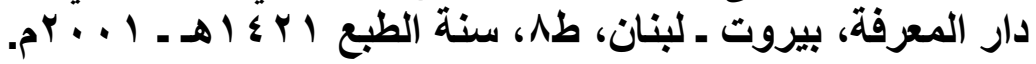

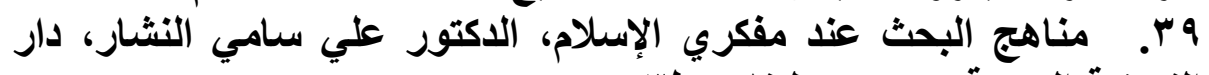

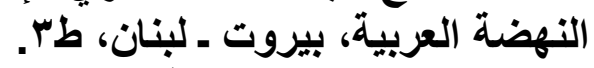

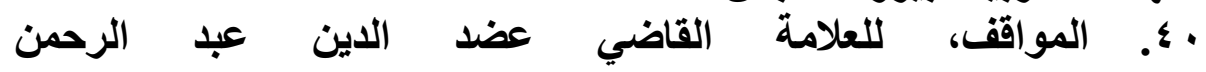

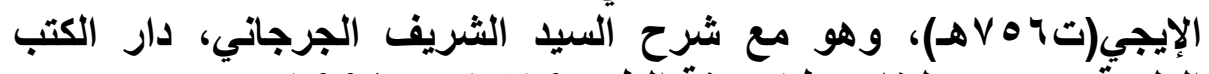

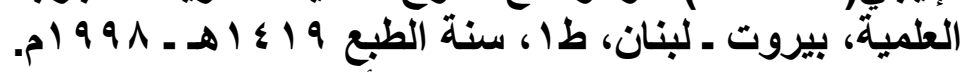
(؛ـ. نثر الطوالع شرح طوالع الأنظار، للقاضي البيضاوي(رحمه الله)

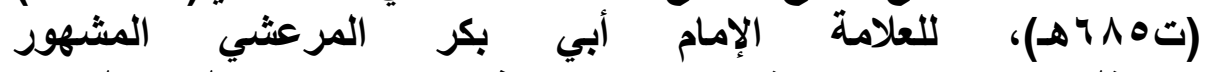

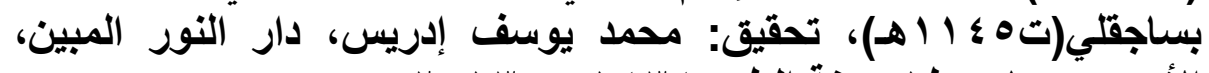

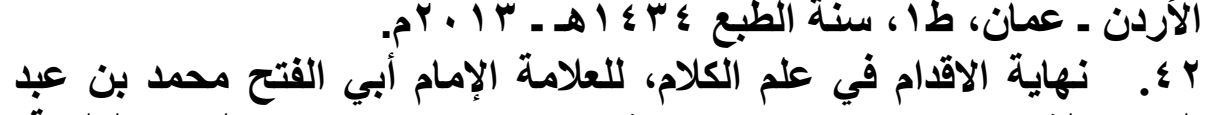

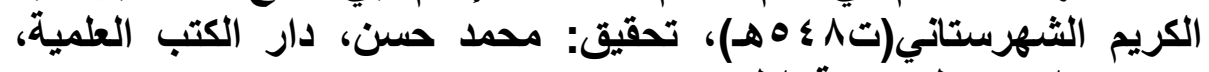

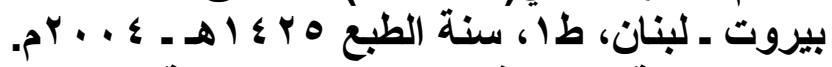

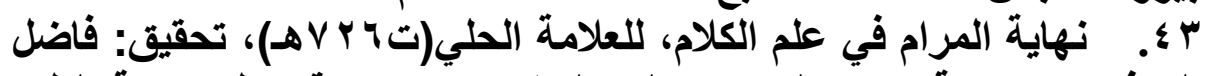

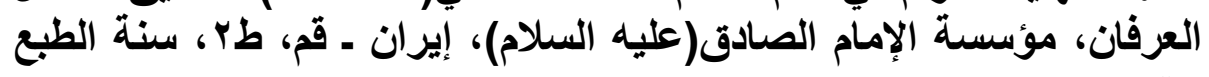

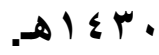

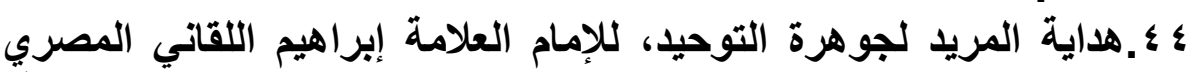

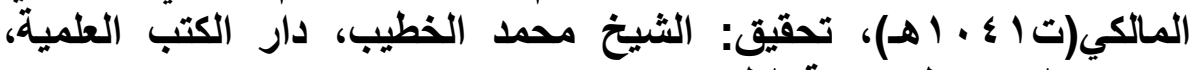

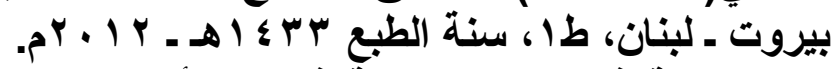

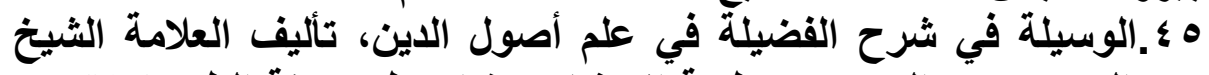

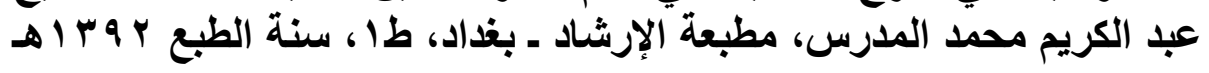

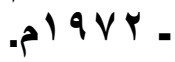

